\title{
Trisomy for chromosome 7 in colorectal neoplasia
}

Citation for published version (APA):

Herbergs, P. J. (1996). Trisomy for chromosome 7 in colorectal neoplasia. [Doctoral Thesis, Maastricht University]. Rijksuniversiteit Limburg. https://doi.org/10.26481/dis.19960530ph

Document status and date:

Published: 01/01/1996

DOI:

10.26481/dis.19960530ph

Document Version:

Publisher's PDF, also known as Version of record

\section{Please check the document version of this publication:}

- A submitted manuscript is the version of the article upon submission and before peer-review. There can be important differences between the submitted version and the official published version of record.

People interested in the research are advised to contact the author for the final version of the publication, or visit the DOI to the publisher's website.

- The final author version and the galley proof are versions of the publication after peer review.

- The final published version features the final layout of the paper including the volume, issue and page numbers.

Link to publication

\footnotetext{
General rights rights.

- You may freely distribute the URL identifying the publication in the public portal. please follow below link for the End User Agreement:

www.umlib.nl/taverne-license

Take down policy

If you believe that this document breaches copyright please contact us at:

repository@maastrichtuniversity.nl

providing details and we will investigate your claim.
}

Copyright and moral rights for the publications made accessible in the public portal are retained by the authors and/or other copyright owners and it is a condition of accessing publications that users recognise and abide by the legal requirements associated with these

- Users may download and print one copy of any publication from the public portal for the purpose of private study or research.

- You may not further distribute the material or use it for any profit-making activity or commercial gain

If the publication is distributed under the terms of Article $25 \mathrm{fa}$ of the Dutch Copyright Act, indicated by the "Taverne" license above, 
Trisomy for chromosome 7

in colorectal neoplasia 
CIP-DATA KONINKLIJKE BIBLIOTHEEK, DEN HAAG

Herbergs, Jos

Trisomy for chromosome 7 in colorectal neoplasia / Jos Herbergs. - [S.I. : s.n.] - III.

Thesis Rijksuniversiteit Limburg, Maastricht. - With ref. - With summary in Dutch.

ISBN: 90-9009472-5

NUGI 743

Subject headings: colorectal tumors / genetic analysis.

○ J Herbergs, Maastricht 1996

cover design: John Muyrers 


\title{
Trisomy for chromosome 7 in colorectal neoplasia
}

\section{Proefschrift}

\author{
ter verkrijging van de graad van doctor \\ aan de Rijksuniversiteit Limburg te Maastricht, \\ op gezag van de Rector Magnificus, Prof. mr. M.J. Cohen, \\ volgens het besluit van het College van Dekanen, \\ in het openbaar te verdedigen \\ op donderdag 30 mei 1996 om 14.00 uur
}

door

Jos Herbergs 
Promotores: Prof. dr. J.W. Arends

Prof. dr. F.C.S. Ramaekers

Co-promotor: Dr. A.H.N. Hopman

Beoordelingscommissie:

Prof. dr. H.F.P. Hillen (voorzitter)

Prof. dr. A. Geurts van Kessel (Katholieke Universiteit Nijmegen)

Prof. dr. M.F. von Meyenfeldt

Prof. dr. G.J.A. Offerhaus (Universiteit van Amsterdam)

Prof. dr. R.W. Stockbrügger 


\section{CONTENTS}

Chapter 1 General Introduction: Genomic changes in colon oncogenesis.

Chapter 2 Combined immunocytochemistry and fluorescence in situ hybridization for simultaneous tricolor detection of cell cycle, genomic, and phenotypic parameters of tumor cells.

Chapter 3 Combination of lamin immunocytochemistry and in situ hybridization for the analysis of chromosome copy numbers in tumor cell areas with high nuclear density.

Chapter 4 Chromosome aberrations in adenomas of the colon. Proof of trisomy for chromosome 7 in tumor cells by combined interphase cytogenetics and immunocytochemistry.

Chapter 5 In situ hybridization and flow cytometric analysis of colorectal tumors suggests two routes of tumorigenesis characterized by gain of chromosome 7 or loss of chromosomes 17 and 18 .

Chapter 6 Clonal origin of trisomy for chromosome 7 in the epithelial compartment of colon neoplasia.

Chapter $7 \quad$ Epilogue.

Chapter 8 Summary.

Samenvatting

Dankwoord 
General introduction:

Genomic changes in colon oncogenesis 


\subsection{General characteristics of colorectal neoplasia}

Colorectal carcinoma constitutes a major health problem, being second in incidence after lung cancer in males and breast cancer in females $10^{\prime}$ Brien, 1988). Abundant epidemiological, clinical and histopathological data suggest that most colorectal carcinomas originate from preexisting adenomas (Morson, 1974; Correa, 1978). It is assumed that progression from a small adenoma to an invasive carcinoma may take between 10 to 15 years. At the time of detection, however, most carcinomas already are in a late stage of development and treatment possibilities are limited, since colon tumors are not very sensitive to radiation therapy or chemotherapy. Surgical resection is the treatment of choice offering the best chance of cure. In case of spread of tumor cells locally or to the liver at the time of operation, minimal residual disease will lead to recurrencies or metastases resulting in death of about $50 \%$ of the patients within 5 years. Obviously, more knowledge about genotypic and phenotypic markers affecting tumor growth and metastasis is necessary to improve treatment of minimal residual disease.

In the last decade it has become clear that cancer can be seen as a "disease of DNA", in which oncogenes and tumor suppressor genes are involved. Since colorectal neoplasia comprises a sequence of events, starting with very smali adenomas and ending with extensive metastatic disease, it allows the study of concomitant genetic alterations involved in the development of this common human malignancy. This has led to the well known cascade of genetic aberrations in colorectal cancer as described by Fearon and Vogelstein (1990).

To gain further !nsight into colorectal tumorigenesis, however, it is necessary to obtain as much information as possible about genomic changes involved in initiation, progression and metastasis of the disease.

\subsection{Genomic changes in colorectal neoplasia}

Pathogenetic events in the multistep process from adenoma to carcinoma involve the accumulation of genomic aberrations. The analysis of such changes can be performed at different levels of resolution and the techniques involved can be classified accordingly, i.e., DNA flow cytometry to detect changes in nuclear DNA content, karyotype analysis to identify gross chromosomal aberrations, fluorescence in situ hybridization (FISH) to analyze genomic changes in interphase nuclei and molecular genetic techniques to study specific rearrangements of 
smaller stretches of DNA.

\subsubsection{DNA flow cytometry}

Flow cytometry can be used for quantitative analysis of the nuclear DNA content and assessment of the percentage of S-phase cells in a relatively large number of cells. Aneuploid cell fractions can thus be detected and their proliferative capacity can be estimated. Table 1 shows that DNA aneuploidy is found in less than $35 \%$ of colorectal adenomas (Giaretti and Santi, 1990; Griffioen et al., 1992; Fischbach et al., 1993; Kimura et al., 1993). In carcinomas aneuploid fractions are found in a range of 35 to $75 \%$ of the cases (reviewed by Dean and Vernava, 1992). This range is probably caused by the wide variety of technical and analytical procedures used, and may be due to differences in the number of cases studied, patient selection, tumor sampling, methods of tissue disaggregation, the use of archival versus fresh material, instrumentation, and data analysis.

Although several groups demonstrated a relation between aneuploidy and prognosis (Schutte et al., 1987; Scott et al., 1987; Witzig et al., 1991), the prognostic value of DNA aneuploidy in colorectal tumor development, as detected by DNA flow cytometry, is still disputed. Recently it was stated that DNA ploidy is a weak prognostic factor and that its role in colorectal carcinoma management is controversial (Bauer et al., 1993).

There are indications, however, that the proliferative activity, as determined by the percentage of $S$ phase cells or cells in $S+G_{2} M$ phase, is a significant prognosticator in colorectal cancer (Schutte et al., 1987; Witzig et al., 1991).

\subsubsection{Karyotyping}

Karyotyping of tumor metaphase spreads is used for the detection of gross structural genomic aberrations. Although valuable information can be obtained by this procedure with respect to colorectal tumor initiation and progression, it is technically difficult to obtain proper chromosome preparations from the epithelial cells of colorectal adenoma and carcinoma, and selection during in vitro culture frequently occurs. For these reasons reliable karyotyping of intestinal adenomas has only become available in recent years and sofar little more than 100 adenoma cases have been analyzed (Longy et al., 1990, 1993; Griffin et al., 1993; Bomme et al., 1994; Muleris et al., 1994). Table 1 shows the most common chromosome aberrations found in adenomas, comprising mostly gain of entire chromosomes 7 
Table 1. DNA content and genetic aberrations in colon adenomas and carcinomas as detected by DNA flow cytometry, karyotyping and loss of heterozygosity (LOH) studies.

\begin{tabular}{|c|c|c|c|}
\hline & DNA content & & Genetic aberrations \\
\hline \multirow{3}{*}{ DNA flow cytometry } & \multicolumn{3}{|c|}{ Adenomas } \\
\hline & $>65 \% \quad:$ diploid & & \\
\hline & $<35 \% \quad$ : aneuploid & & \\
\hline \multirow[t]{2}{*}{ Karyotyping } & $20-50 \%$ : diploid & $20-50 \%$ & $:-1 p,+7,-8 p,+8 q,+9,+12$ \\
\hline & $50-80 \%$ : aneuploid & & $+13,+16,-17 p,-18,+20$ \\
\hline \multirow[t]{2}{*}{ LOH studies } & & $20-30 \%$ & $:$ LOH of $5 q, 17 p, 18 q$ \\
\hline & \multicolumn{3}{|c|}{ Carcinomas } \\
\hline \multirow[t]{2}{*}{ DNA flow cytometry } & $25-65 \%$ : diploid & & \\
\hline & $35-75 \%$ : aneuploid & & \\
\hline \multirow[t]{3}{*}{ Karyotyping } & $5-25 \% \quad:$ diploid & $75 \%$ & $:-17 p$ \\
\hline & $75-95 \%$ : aneuploid & $20-80 \%$ & $:-18$ \\
\hline & & $20-50 \%$ & $\begin{array}{l}: \operatorname{del}(1)(p 3),-4 q, \operatorname{del}(5)(q 2), \\
-6 q,+7,-8 p,+8 q,-9 q \\
\operatorname{del}(10)(q 2),-11,+12,+13 \\
-14,-15,+20,-21,-22, \\
+X,-Y\end{array}$ \\
\hline \multirow[t]{2}{*}{ LOH studies } & & $60-80 \%$ & $:$ LOH of $17 p, 18 q$ \\
\hline & & $20-50 \%$ & $\begin{array}{l}: \text { LOH of } 1 p, 1 q, 5 q, 6 q, 8 p \text {, } \\
11 q, 14 q, 17 q, 18 p, 22 q\end{array}$ \\
\hline
\end{tabular}

and 13, but also frequent gain of chromosomes 9, 12, 16 and 20. Many studies report deletions in or loss of chromosomes $1 p, 8 p, 17 p$ and 18 . In the more than 200 analyzed carcinomas the most frequently occurring chromosome aberrations are loss of the p-arm of chromosome 17 and loss of chromosome 18 (Muleris et al., 1990b; Bardi et al., 1995). Most of the aberrations observed in carcinomas are already found in adenomas, although in lower frequencies. These findings strengthen the concept of the adenoma-carcinoma sequence.

Since the sensitivity of the methods applied for karyotyping of solid tumors has improved, and thus more detailed analysis can be performed, the percentage of reported aberrant cases has increased, together with a more frequent finding of 
cytogenetic heterogeneity (Bardi et al., 1993a,b, 1995).

Until now, no clearcut correlations between detected chromosome aberrations and prognosis have been established, although Bardi et al. (1995) found an inverse correlation between the number of detected structural chromosome rearrangements and survival.

\subsubsection{FISH}

The FISH technique is now routinely applied for detection of genomic aberrations in interphase nuclei. Furhermore, simultaneous analysis of morphological and genomic features can be performed, which is important to obtain information about phenotypic and genotypic characteristics of tumor cells. Surprisingly, however, sofar no important studies have been performed on colorectal tumors using this technique.

\subsubsection{Molecular genetics}

The molecular approach to colon tumorigenesis has led to the detection of a considerable number of genes involved in colorectal tumor development and progression. Restriction fragment length polymorhism (RFLP) analysis has been applied to determine whether one of the two parental alleles is specifically lost in tumors. Allelic loss has been interpreted as evidence that the affected regions contain tumor suppressor genes, whose products normally restrain cell growth. Table 1 shows the most frequent sites of allelic loss in colorectal tumors, which mainly have been noted on chromosomes $5 q, 17 p$ and $18 q$ in adenomas as well as in carcinomas. In carcinomas loss of heterozygosity (LOH) of $17 p$ and $18 q$ is more frequently found than in adenomas, and also for other alleles, like $1 p, 1 q$, $6 q, 8 p, 11 q, 14 q$ and $17 q \mathrm{LOH}$ is observed (Vogelstein et al., 1988, 1989; Delattre et al., 1989; Sasaki et al., 1989; Leister et al., 1990; Leone et al., 1991; Young et al., 1993; Gustafson et al., 1994). The tumor suppressor genes associated with these forms of allelic loss are the APC (adenomatous polyposis coli) gene on chromosome $5 q$, which contains germ line mutations in individuals with familiar adenomatous polyposis (FAP) (Kinzler et al., 1991; Nishisho et al., 1991), the MCC (mutated in colorectal cancer) gene on chromosome $5 q$ (Kinzler et al., 1991; Nishisho et al., 1991), the p53 gene on chromosome 17p (Baker et al., 1989; Nigro et al., 1989), and the DCC (deleted in colorectal cancer) gene on chromosome 18q (Fearon et al., 1990). Allelic loss on chromosomes 17p and 
$18 q$ is considered to be a late event in tumorigenesis (Fearon et al., 1990) and is associated with a poor prognosis (Laurent-Puig et al., 1992; Offerhaus et al., 1992; Jen et al., 1994).

An oncogene known to be involved in colon tumorigenesis, the K-ras gene, is mutated in about $50 \%$ of adenomas larger than $1 \mathrm{~cm}$ in diameter, as well as in carcinomas (Bos et al., 1987; Forrester et al., 1987; Vogelstein et al., 1988). A recent study suggests that the type and number of $\mathrm{K}$-ras mutations are related to the stage of colorectal cancer (Moerkerk et al., 1994).

In recent years mutations in mismatch repair genes have been found in the germline of hereditary nonpolyposis colorectal cancer (HNPCC) patients, namely in the genes hMSH2, hMLH1, hPMS1 and hPMS2 (Fishel et al., 1993; Leach et al., 1993; Nicolaides et al., 1994; Papadopoulos et al., 1994). These genes also seem to be involved in some sporadic colorectal cancer cases (Liu et al., 1995).

\subsection{Genetic models for colorectal tumorigenesis}

The genomic changes that were detected with the different methods described above have led to models which attempt to describe the sequence of DNA alterations during the multistep process of colorectal tumorigenesis.

\subsubsection{A model based on molecular genetics}

The molecular genetic studies mentioned before have resulted in the well known model described by Fearon and Vogelstein (1990)(Figure 1A), in which inactivation of the APC gene, mutations in mismatch repair genes, $\mathrm{LOH}$ for chromosome $5 q$ (APC, MCC), K-ras mutations, $\mathrm{LOH}$ for chromosome 18q (DCC), p53 mutations and LOH for chromosome $17 p$ are the major events. The concept proposes that colorectal cancer results from the accumulation of multiple mutations in oncogenes ( $\mathrm{K}$-ras) and tumor suppressor genes (APC, MCC, DCC, p53) and that the total accumulation of changes, rather than their sequence, appears to be critical in determining tumor cell behaviour.

\subsubsection{A model based on DNA flow cytometry}

Recently, Giaretti (1994) suggested a model for colon tumorigenesis based on DNA flow cytometry data obtained in a series of adenomas and carcinomas. This model is schematically presented in Figure $1 \mathrm{~B}$, and is based on the DNA index 
(DI; i.e., the amount of DNA in the tumor relative to the normal DNA content). This model demonstrates how loss and gain of chromosomes, in combination with other mechanisms, such as unbalanced rearrangements, may generate two daughter cells with a near-diploid DNA content. The loss of symmetry in DNA cell division may result in different DNA contents in the two daughter cells. This can originate from either loss of genetic material (i.e., complete chromosomes or chromosome fragments) from mitotic cells or by impairment and damage of the complex control mechanisms leading to exact DNA division in normal mitotic cells (Mitchison, 1989). Subsequently, endoreduplication of a hypodiploid cell generates an abnormal mitosis which divides asymmetrically, resulting in two daughter cells with DI values smaller than 2.0. DNA subclones with DI greater than 2.0 , which are found in $7 \%$ of colorectal adenocarcinomas, are likely to be derived from tetraploidization of aneuploid cells with a DI greater than 1.0. As a result, early aneuploidy in the process of colon tumorigenesis is caused by loss of DNA symmetry during cell division involving abnormal mitosis, and by subsequent tetraploidization of near-diploid (particularly hypodiploid) subclones. Hyperdiploid subclones are more often found than hypodiploid subclones, indicating that the latter are generally less viable.

Atypical mitoses have been reported to occur abundantly in colorectal adenomas (Rubio et al., 1991) and the existence of near-diploid colorectal tumors is in agreement with cytogenetic studies reporting non-random structural abnormalities, as well as chromosomal gain and loss (Muleris et al., 1990b; Bardi et al., 1995).

\subsubsection{A model based on karyotyping}

On the basis of karyotype analysis of colorectal adenomas and carcinomas, a model is postulated (Figure $1 \mathrm{C}$ ) showing two distinct pathways of karyotypic evolution: one mainly resulting from chromosomal deletions (the monosomic subgroup), the other essentially involving progressive gain of chromosomes (the trisomic subgroup; Muleris et al., 1988, 1990a; Longy et al., 1993). The trisomic subgroup is mainly characterized by gain of entire chromosomes, especially chromosome 7 , and is found in about $20 \%$ of the karyotyped tumors (Muleris et al., $1988,1990 \mathrm{~b})$. In the monosomic subgroup, which is observed in about $70 \%$ of the analyzed carcinomas, the characteristic aberrations are monosomy for chromosome 18 and monosomy for $17 \mathrm{p}$. It is assumed that endoreduplication mainly occurs in these monosomic tumor types (Muleris et al., 1990b), leading to 
A. Model based on molecular genetics

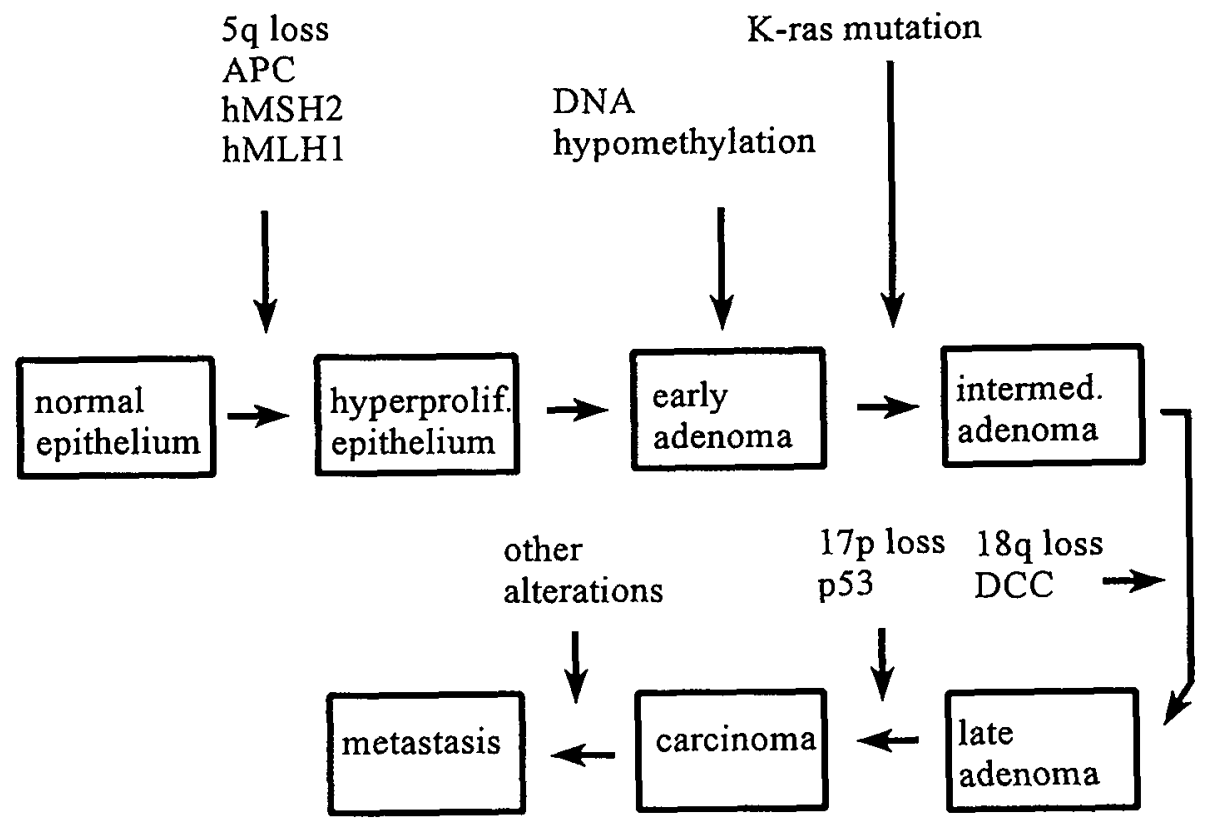

B. Model based on DNA flow cytometry

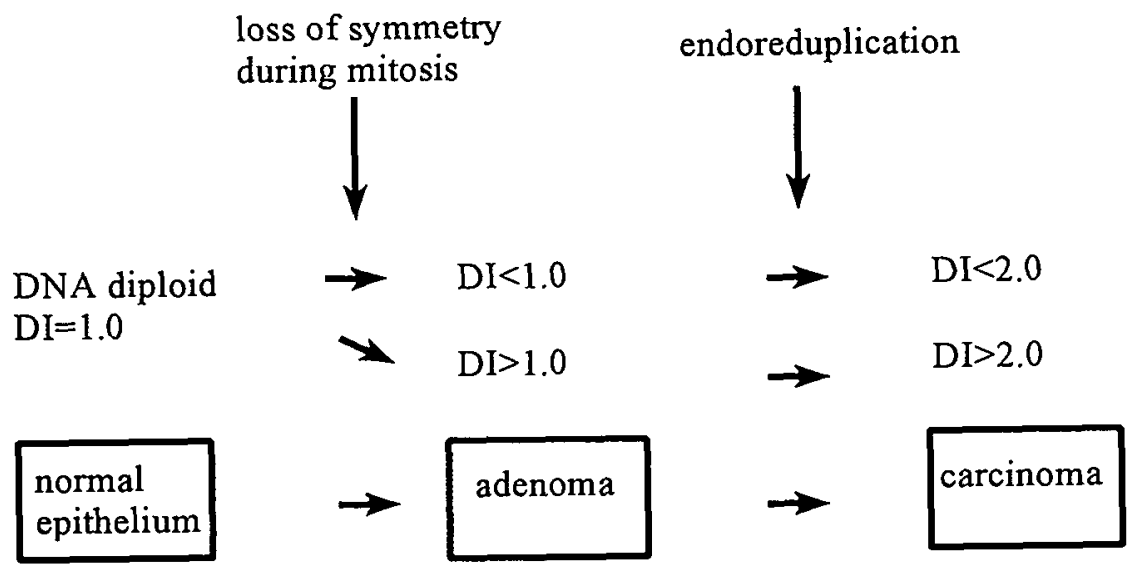




\section{Model based on karyotyping}

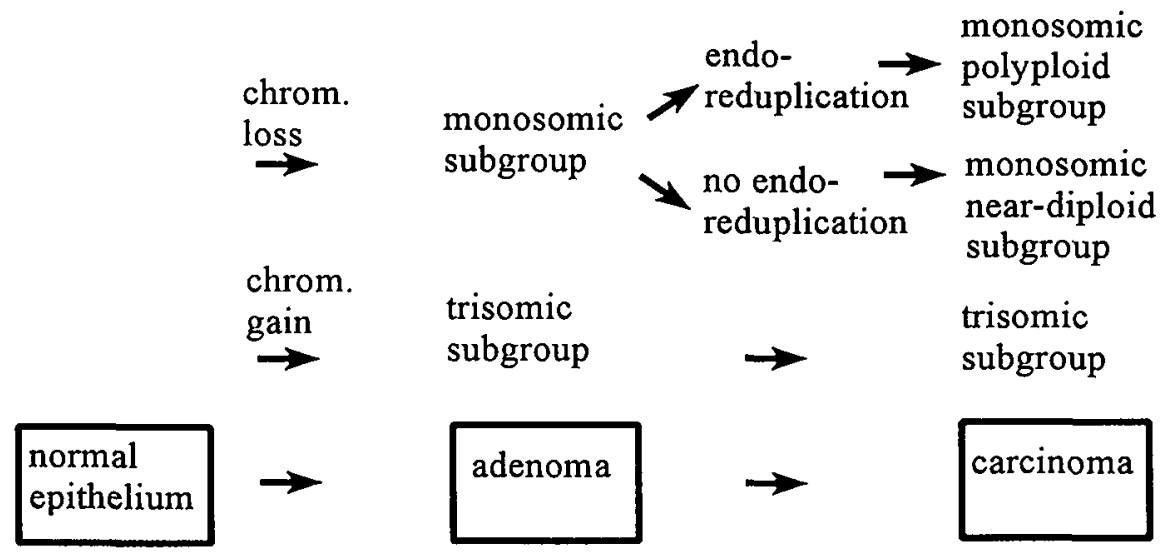

Figure 1. Three models for colorectal tumorigenesis based on A) molecular genetics, B) DNA flow cytometry , and C) karyotyping.

monosomic polyploid tumors. The trisomic lineage is more frequently seen in the adenoma than in the carcinoma stage, and it is therefore suggested that this trisomic group rarely evolves into malignancy. The group with a deletional karyotype, analogous to the monosomy group, is seen more rarely in the adenomatous stage as compared to the carcinoma stage. It is postulated therefore, that this group more frequently develops into malignancy.

\subsection{Current status of genomic colorectal cancer research}

Although the genetic cascade as described by Fearon and Vogelstein (1990) reveals important information about colorectal tumorigenesis, this is still far from complete. For example, gain of genomic material, which may be as important as loss of genetic material, is not included. The models for colorectal tumorigenesis as described by Giaretti (1994) on the basis of DNA flow cytometry and Muleris $(1990 a, b)$ based upon karyotyping may therefore give valuable additional information. Since all three models described above, however, show partly different pathways for colorectal carcinogenesis, it is obvious that the complete 
picture of all genetic aberrations involved in initiation and progression of colorectal cancer is still not available. To obtain more information about genomic aberrations in colorectal tumorigenesis FISH was used in our study, since this technique enables the detection of genomic aberrations in interphase nuclei at the single cell level. Furthermore, the genetic aberrations can be detected in tumor sections and therefore be correlated with morphological characteristics. Finally, hardly any report, sofar, is made on the use of FISH in the analysis of genomic alterations playing part in colorectal tumorigenesis.

\subsection{Scope of this thesis}

Against this background the aim of the investigations in this thesis was to study the chromosomal composition of normal colon epithelium, colonic adenomas as well as colonic carcinomas using FISH, and to compare these data with the models based upon other techniques. For simultaneous detection of genotypic and phenotypic characteristics in cell suspensions and for better analysis of FISH signals in tissue sections, which is hampered by nuclear overlap, technical adaptations had to be made. The adapted techniques were subsequently applied to investigate whether or not trisomy for chromosome 7, an aberration detected at an early stage of our investigations in colorectal adenomas and increasingly found in carcinomas, represents a relevant genomic aberration in colon carcinogenesis.

\section{References}

Baker SJ, Fearon ER, Nigro JM, Hamilton SR, Preisinger AC, Jessup JM, vanTuinen P, Ledbetter D, Barker DF, Nakamura Y, White R, Vogelstein B (1989) Chromosome 17 deletions and p53 gene mutations in colorectal carcinomas. Science 244:217-221

Bardi G, Johansson B, Pandis N, Bak-Jensen E, Örndal C, Heim S, Mandahl N, AndrénSandberg $\AA$, Mitelman F (1993a) Cytogenetic aberrations in colorectal adenocarcinomas and their correlation with clinicopathologic features. Cancer 3:149-152

Bardi G, Johansson B, Pandis N, Mandahl N, Bak-Jensen E, Lindström C, Törnquist A, Frederiksen H, Andrén-Sandberg $\AA$, Mitelman F, Heim S (1993b) Cytogenetic analysis of 52 colorectal carcinomas - non-random aberration pattern and correlation with pathologic parameters. Int J Cancer 55:422-428 
Bardi G, Sukhikh T, Pandis N, Fenger C, Kronborg O, Heim S (1995) Karyotypic characterization of colorectal adenocarcinomas. Genes Chromosom Cancer 12:97-109

Baver KD, Bagwell CB, Giaretti W, Melamed M, Zarbo RJ, Witzig TE, Rabinovitch PS (1993) Consensus review of the clinical utility of DNA flow cytometry in colorectal cancer. Cytometry 14:486-491

Bomme L, Bardi G, Pandis N, Fenger C, Kronborg O, Heim S (1994) Clonal karyotypic abnormalities in colorectal adenomas: clues to the early genetic events in the adenomacarcinoma sequence. Genes Chromosom Cancer 10:190-196

Bos JL, Fearon ER, Hamilton SR, Verlaan-de Vries M, Van Boom JH, Van der Erb AJ, Vogelstein B (1987) Prevalence of ras gene mutations in human colorectal cancers. Nature 327:293-297

Correa P (1978) Epidemiology of polyps and cancer. Major Probl Pathol 10:126-152

Dean PA, Vernava AM III (1992) Flow cytometric analysis of DNA content in colorectal carcinoma. Dis Colon Rectum 35:95-102

Delattre P, Olschwang S, Law DJ, Melot T, Remvikos Y, Salmon RJ, Sastre X, Validire P, Feinberg AP, Thomas $G$ (1989) Multiple genetic alterations distinguish distal from proximal colorectal cancer. Lancet 2:353-356

Fearon ER, Vogelstein B (1990) A genetic model for colorectal tumorigenesis. Cell 61:759767

Fearon ER, Cho KR, Nigro JM, Kern SE, Simons JW, Ruppert JM, Hamilton SR, Preisinger AC, Thomas G, Kinzler KW, Vogelstein B (1990) Identification of a chromosome 18q gene that is alterd in colorectal cancers. Science 247:49-56

Fischbach W, Zidianakis Z, Luke G, Kirchner T, Mossner J (1993) DNA mapping of colorectal neoplasms: a flow cytometric study of DNA abnormalities and proliferation. Gastroenterology 105:1126-1133

Fishel R, Kay Lescoe M, Rao MRS, Copeland NG, Jenkins NA, Garber J, Kane M, Kolodner $R$ (1993) The human mutator gene homolog $M S H 2$ and its association with hereditary nonopolyposis colon cancer. Cell 75:1027-1038

Forrester K, Almoguera C, Han K, Grizzle WE, Perucho M (1987) Detection of high incidence of K-ras oncogenes during human colon tumorigenesis. Nature 327:298-303 
Giaretti W, Santi L (1990) Tumor progression by DNA flow cytometry in human colorectal cancer. Int J Cancer 45:597-603

Giaretti W (1994) A model of DNA aneuploidization and evolution in colorectal cancer. Lab Invest 71:904-910

Griffin CA, Lazar S, Hamilton SR, Giardiello FM, Long P, Krush AJ, Booker SV (1993) Cytogenetic analysis of intestinal polyps in polyposis syndromes: comparison with sporadic colorectal adenomas. Cancer Genet Cytogenet 67:14-20

Griffioen G, Cornelisse CJ, Verspaget HW, Sier CF, Eulderink F, Bosman FT, Lamers CB (1992) Association of aneuploidy in index adenomas with metachronous colorectal adenoma development and a comparison. Cancer 70:2035-2043

Gustafson CE, Young J, Leggett B, Searle J, Chenevix-Trench G (1994) Loss of heterozygosity on the long arm of chromosome 11 in colorectal tumours. $\mathrm{Br} \mathrm{J}$ Cancer $70: 395-397$

Jen J, Kim H, Piantadosi S, Liu ZF, Levitt RC, Sistonen P, Kinzler KW, Vogelstein B, Hamilton SR (1994) Allelic loss of chromosome 18q and prognosis in colorectal cancer. $N$ Engl J Med 331:213-221

Kimura H, Kanno M, Takamura H, Arakawa H, Maeda K, Uogishi M, Sodani H, Kawashima $T$ (1993) Histopathologic and flow cytometric analysis of colorectal polyps resected at endoscopy. Eur Surg Res 25:187-192

Kinzler KW, Nilbert MC, Su LK, Vogelstein B, Bryan TM, Levy DB, Smith KJ, Preisinger AC, Hedge P, McKechnie D, Finniear R, Markham A, Groffen J, Boguski MS, Altschul F, Horii A, Ando $H$, Miyoshi $Y$, Miki $Y$, Nishisho I, Nakamura $Y(1991)$ Identification of FAP locus genes from chromosome 5q21. Science 253:661-665

Laurent-Puig P, Olschwang S, Delattre O, Remvikos $Y$, Asselain B, Melot T, Validire P, Muleris M, Girodet J, Salmon RJ (1992) Survival and acquired genetic alterations in colorectal cancer. Gastroenterology 102:1136-1141

Leach FS, Nicolaides NC, Papadopoulos N, Liu B, Jen J, Parsons R, Peltomäki P, Sistonen P, Aaltonen LA, Nyström-Lahti M, Guan XY, Zhang J, Meltzer PS, Yu JW, Kao FT, Chen DJ, Cerosaletti KM, Fournier REK, Todd S, Lewis T, Leach RJ, Naylor SL, Weissenbach J, Mecklin JP, Järvinen $H$, Petersen GM, Hamilton SR, Green J, Jass J, Watson P, Lynch HT, Trent JM, De la Chapelle A, Kinzler KW, Vogelstein B (1993) Mutations of a mutS homolog in hereditary nonpolyposis colorectal cancer. Cell 75:1215-1225 
Leister 1, Weith A, Brüderlein S, Cziepluch C, Kangwanpong D, Schlag P, Schwab F (1990) Human colorectal cancer: high frequency of deletions at chromosome $1 p 35$. Cancer Res 50:7232-7235

Leone A, McBride OW, Weston A, Wang MG, Anglard P, Cropp CS, Goepel JR, Lidereau R, Callahan R, Linehan WM. Rees RC, Harris CC, Liotta LA, Steeg PS (1991) Somatic allelic deletion of nm23 in human cancer. Cancer Res 51:2490-2493

Liu B, Nicolaides NC, Markowitz S, Willson JKV, Parsons RE, Jen J, Papadopoulos N, Peltomäki P, De la Chapelle A, Hamilton SR, Kinzler KW, Vogelstein B (1995) Mismatch repair gene defects in sporadic colorectal cancers with microsatellite instability. Nature Genet 9:48-55

Longy M, Saura R, Schouler L, Mauhin C, Goussot JF, Grison O, Couzigou P (1990) Chromosomal analysis of colonic adenomatous polyps. Cancer Genet Cytogenet 49:249257

Longy M, Saura R, Dumas F, Leseve JF, Taine L, Goussot JF, Couzigou P (1993) Chromosome analysis of adenomatous polyps of the colon: possible existence of two differently evolving cytogenetic groups. Cancer Genet Cytogenet 67:7-13

Mitchison TJ (1989) Mitosis:basic concepts. Curr Opinion Cell Biol 1:67-74

Moerkerk P, Arends JW, Van Driel M, De Bruine A, De Goeij A, Ten kate J (1994) Type and number of $\mathrm{Ki}$-ras point mutations relate to stage of human colorectal cancer. Cancer Res 54:3376-3378

Morson BC (1974) The polyp-cancer sequence in the large bowel. Proc R Soc Med 67:451457

Muleris M, Salmon RJ, Dutrillaux B (1988) Existence of two distinct processes of chromosomal evolution in near-diploid colorectal tumors. Cancer Genet Cytogenet 32:4350

Muleris M, Delattre O, Olschwang S, Dutrillaux A, Remvikos $Y$, Salmon RJ, Thomas G, Dutrillaux B (1990a) Cytogenetic and molecular approaches of polyploidization in colorectal adenocarcinomas. Cancer Genet cytogenet 44:107-118

Muleris M, Salmon RJ, Dutrillaux B (1990b) Cytogenetics of colorectal adenocarcinomas. Cancer Genet Cytogenet 46:143-156 
Muleris M, Zafrani B, Validire P, Girodet J, Salmon RJ, Dutrillaux B (1994) Cytogenetic study of 30 colorectal adenomas. Cancer Genet Cytogenet 74:104-108

Nigro JM, Baker SJ, Preisinger AC, Jessup JM, Hostetter R, Cleary K, Bigner SH, Davidson N, Baylin S, Devilee P, Glover T, Collins FS, Weston A, Modali R, Harris CC, Vogelstein B (1989) Mutations in the p53 gene occur in diverse human tumour types. Nature 342:705707

Nicolaides NC, Papadopoulos N, Liu B, Wei YF, Carter KC, Ruben SM, Rosen CA, Haseltine WA, Freischmann RD, Fraser CM, Adams MD, Venter JC, Dunlop MG, Hamilton SR, Petersen GM, De la Chapelle A, Vogelstein B, Kinzler KW (1994) Mutations of two PMS homologues in hereditary nonpolyposis colon cancer. Nature 371:75-80

Nishisho I, Nakamura $Y$, Miyoshi $Y$, Miki $Y$, Ando $H$, Horii A, Koyama K, Utsonomiya J, Baba S, Hedge P, Markham A, Krush AJ, Petersen G, Hamilton SR, Nilbert MC, Levy DB, Bryan TM, Preisinger AC, Smith KJ, Su LK, Kinzler KW, Vogelstein B (1991) Mutations of chromosome $5 q 21$ genes in FAP and colorectal cancer patients. Science 253:665-669

O'Brien MJ (1988) Cancer of the colon and rectum: current concepts of aetiology and pathogenesis. Ir J Med Sci 157:5-15

Offerhaus GJA, De Feyter EP, Cornelisse CJ, Tersmette KWF, Floyd J, Kern SE, Vogelstein $B$, Hamilton SR (1992) The relationship of DNA aneuploidy to molecular genetic alterations in colorectal carcinoma. Gastroenterology 102:1612-1619

Papadopoulos N, Nicolaides NC, Wei YF, Ruben SM, Carter KC, Rosen CA, Haseltine WA, Fleischmann RD, Fraser CM, Adams MD, Venter JC, Hamilton SR, Petersen GM, Watson P, Lynch HT, Peltomäki P. Mecklin JP, De la Chapelle A, Kinzler KW, Vogelstein B (1994) Mutation of a mutL homolog in hereditary colon cancer. Science 263:1625-1629

Rubio CA (1991) Atypical mitosis in colorectal adenomas. Path Res Pract 187:508-513

Sasasaki M, Okamoto M, Sato C, Sugio K, Soejima J, Iwama T, Ikeuchi T, Tonomura A, Miyaki M, Sasazuki $T$ (1989) Loss of constitutional heterozygosity in colorectal tumors from patients with familial polyposis coli and those with nonpolyposis colorectal carcinoma. Cancer Res 49:4402-4406

Schutte B, Reynders MMJ, Wiggers T, Arends JW, Volovics L, Bosman FT, Blijham GH (1987) Retrospective analysis of the prognostic significance of DNA content and proliferative activity in large bowel carcinoma. Cancer Res 47:329-335 
Scott NA, Wieand HS, Moertel CG, Cha SS, Beart RW, Lieber MM (1987) Colorectal cancer. Dukes stage, tumor site, preoperative plasma CEA level, and patient prognosis related to tumor DNA ploidy pattern. Arch Surg 122:1375-1379

Vogelstein B, Fearon ER, Hamilton SR, Kern SE, Preisinger AC, Leppert M, Nakumura Y, White R, Smits AMM, Bos JL (1988) Genetic alterations during colorectal-tumor development. N Engl J Med 319:525-532

Vogelstein B, Fearon ER, Kern SE, Hamilton SR, Preisinger AC, Nakamura Y, White R (1989) Allelotype of colorectal carcinomas. Science 244:207-211

Witzig TE, Loprinzi CL, Gonchoroff NJ, Reiman HM, Cha SS, Wieand HS, Katzmann JA, Paulsen JK, Moertel CG (1991) DNA ploidy and cell kinetic measurements as predictors of recurrence and survival in stages $B 2$ and $C$ colorectal adenocarcinoma. Cancer 68:879-888

Young J, Leggett B, Ward M, Thomas L, Buttenshaw R, Searle J, Chenexix-Trench G (1993) Frequent loss of heterozygosity on chromosome 14 occurs in advanced colorectal carcinomas. Oncogene 8:671-675 
Combined immunocytochemistry and fluorescence in situ hybridization for simultaneous tricolor detection of cell cycle, genomic, and phenotypic parameters of tumor cells

Ernst JM Speel, Jos Herbergs, Frans CS Ramaekers and Anton HN Hopman

$J$ Histochem Cytochem 42, 961-966, 1994 


\section{Abstract}

We describe the development and application of a sensitive high-resolution fluorescence alkaline phosphatase (APase)-Fast Red immunocytochemical (ICC) staining method in combination with fluorescence in situ hybridization (ISH) and bromodeoxyuridine (BrdU) detection. The high fluorescence intensity, accurate localization, and advantageous slow-fading properties make the APase-Fast Red reaction a valuable tool for the detection of antigens or specific DNA probes in biological cell preparations. Since the enzyme precipitate proved to be resistant to enzymatic pre-treatment steps and stable during the entire ISH procedure, APaseFast Red immunostaining could be combined with subsequent visualization of DNA target sequences by fluorescence ISH. The lung cancer cell lines $\mathrm{NCl}-\mathrm{H} 82$ and EPLC 65 were used as a model system for simultaneous detection of cell proteins, such as the neural cell adhesion molecule (N-CAM), cytokeratin filaments, lamin, or the Ki67 antigen (Ki67-Ag), and centromere-specific DNA probes for the human chromosomes 1,7 , or 17 . In addition, the combined ICC/ISH procedure could be extended with the immunodetection of $\mathrm{BrdU}$ incorporated by tumor cells in S-phase. As a consequence, a combined $I \mathrm{CC} / \mathrm{ISH} / \mathrm{BrdU}$ detection procedure is now available that enables analysis of relatively complex tumor populations on the basis of different ICC and genetic markers as well as proliferative activity.

\subsection{Introduction}

A variety of immunocytochemical (ICC) and in situ hybridization (ISH) methods give insight into the presence or absence of specific proteins and nucleic acid sequences or establish kinetic parameters of tumor cells. The combination of these techniques in the same biological specimen has proven advantageous in, e.g., demonstrating simultaneously the presence of mRNA and its protein product in one cell (Wolfson et al., 1985; Larsson and Hougaard, 1991; Dirks et al., 1993; Trembleau et al., 1993), immunophenotyping cells containing a specific chromosomal aberration or viral infection (Gendelman et al., 1985; Porter et al., 1990; Losada et al., 1991; Van den Berg et al., 1991; Strehl and Ambros, 1993; Weber-Matthiesen et al., 1993), or characterization of cytokinetic parameters of tumor cell populations that are genetically or phenotypically aberrant (Schutte et al., 1987; Balazs et al., 1991; Van Dekken et al., 1991).

For a successful combination of ICC and non-radioactive ISH, several factors 
must be taken into account. Preservation of cell morphology and protein epitopes, accessibility of nucleic acid targets, and stability of enzyme cytochemical precipitates and fluorochromes all determine the success rate and sensitivity of the procedure. Since several steps in the ISH procedure, e.g., enzymatic digestion, post-fixation, denaturation at high temperatures, and hybridization in formamide, can destroy antigenic determinants, a combined procedure, starting with ICC and followed by ISH, is preferred in most cases. Several such combined ICC/ISH methods have been described with either enzyme precipitation reactions (Mullink et al., 1989; Porter et al., 1990; Van den Brink et al., 1990; Losada et al., 1991), fluorochromes (Van den Berg et al., 1991; Weber-Matthiesen et al., 1993), or a combination of both (Strehl and Ambros, 1993). ICC detecion of proteins with stable enzyme reaction products allows optimal pre-treatment of the specimens before the ISH step.

Here we report on the usefulness of the alkaline phosphatase (APase)-Fast Red reaction in the ICC step before ISH. This detection method produces a strongly red fluorescent reaction product with a virtually permanent character that can be accurately localized under optimal conditions (Speel et al., 1992b). The resolution of the APase-Fast Red reaction was optimized for detection of DNA targets and for different cellular protein components. Once optimized, the APase-Fast Red reaction was utilized in both fluorescence $\mathrm{ISH}$ and combined $\mathrm{ICC} / \mathrm{ISH}$ procedures. Finally, we combined the APase-Fast Red antigen staining with fluorescence ISH and bromodeoxyuridine (BrdU) detection, thus allowing for the first time detection of phenotypic, genotypic, and cell kinetic parameters in the same cell.

\subsection{Materials and methods}

\section{Preparation of metaphase spreads}

Chromosomes were prepared from peripheral blood by phytohemagglutinin stimulation, hypotonic spreading, and fixation in methanol:acetic acid $(3: 1 \mathrm{v} / \mathrm{v})$. Pre-treatment of the metaphase spreads with RNase $A$ and pepsin, followed by post-fixation in 1\% formaldehyde in phosphate-buffered saline (PBS: $0.15 \mathrm{M}$ $\mathrm{NaCl}, 10 \mathrm{mM}$ Na phosphate, $\mathrm{pH} 7.2$ ), has been described previously (Speel et al., 1992b).

\section{Cell preparations and BrdU labeling}

Cell preparations were made from a cell suspension of human transitional cell carcinoma line T24 [DNA index 1.6; trisomic for the centromeres of 
chromosomes 1 and 7; (Bubeník et al., 1973)]. Fixation and removal of cytoplasm to improve DNA probe and conjugate penetration were performed as described earlier (Speel et al., 1992a). The human small-cell lung cancer cell line $\mathrm{NCl}-\mathrm{H} 82$ and the human squamous-cell lung carcinoma cell line EPLC 65 were grown as described by Broers et al. (1988). BrdU labeling of cells was performed by adding BrdU to a final concentration of $10 \mu \mathrm{M}$ to the culture medium $30 \mathrm{~min}$ before harvesting of the cells. The floating $\mathrm{NCl}-\mathrm{H} 82$ cells were cytospun onto glass slides (1000 rpm for $5 \mathrm{~min}$ ) and air-dried for $1 \mathrm{hr}$ at room temperature (RT). EPLC 65 cells were grown on glass coverslips for 2 days. Cells were fixed by dipping in cold methanol $\left(-20^{\circ} \mathrm{C}\right)$ for $5 \mathrm{sec}$ and acetone $\left(4^{\circ} \mathrm{C}\right)$ three times for $5 \mathrm{sec}$ and were stored at $-20^{\circ} \mathrm{C}$ until use.

\section{DNA probes and labeling procedure}

The probes for the (sub)centromeric regions of human chromosomes 1 (pUC 1.77), 7 ( $\mathrm{p} 7 \mathrm{t} 1)$, and 17 (p17H8), as well as the cosmid clone cCll11-314, specific for $40 \mathrm{~kb}$ of DNA target on chromosome 11q23, have been described earlier (Cooke and Hindley, 1979; Waye and Willard, 1986; Waye et al., 1987; Tokino et al., 1991). The DNA probes were labeled with either biotin-11-dUTP (Enzo Diagnostics, New York, NY, USA), digoxigenin-11-dUTP, or fluorescein isothiocyanate (FITC)-12-dUTP (Boehringer, Mannheim, Germany) in a standard nick-translation reaction.

\section{ISH procedures}

The (sub)centromere probes and the cosmid probe were hybridized in single- and double-target ISH on metaphase spreads and on T24 cells, as described earlier (Speel et al., 1992a, 1993). After stringent post-hybridization washes, the digoxigenin-labeled probes were detected with subsequent detection steps of mouse anti-digoxin (MADig, 1:2000) (Sigma, St. Louis, MO, USA) and FITCconjugated rabbit anti-mouse IgG (RAMFITC, 1:80) (Dako, Glostrup, Denmark). whereas the biotinylated DNA probes were detected by a three-step avidinbiotinylated enzyme complex $(A B C)$ detection system using the APase-Fast Red reaction (Speel et al., 1992b).

\section{ICC procedures}

The following polyclonal and monoclonal antibodies were used for the detection of cellular proteins: (a) a 1:5 dilution of affinity-purified polyclonal rabbit antibody raised against human skin cytokeratin filaments, which reacts with virtually all 
epithelial tissues (Ramaekers et al., 1983); (b) a 1:10 dilution of the monoclonal antibody (MAb) RCK102 to human cytokeratin filaments 5 and 8 (Broers et al., 1988); (c) a 1:10 dilution of an affinity-purified polyclonal rabbit antibody raised against the proliferation marker protein Ki67-Ag (Dako; a kind gift of Dr. J. Askaa); (d) a 1:5 dilution of MAb Ki67 (Dako);(e) undiluted culture supernatant of MAb LN43, directed against lamin B2 la kind gift from Dr. E.B. Lane, Dundee, U.K.); and (f) undiluted culture supernatant of MAb RNL1, directed against the neural cell adhesion molecule N-CAM (Boerman et al., 1991).

For the ICC procedures, cells were first blocked with PBS containing $0.05 \%$ Tween 20 (Buffer $A$ ) and $2 \%$ normal goat serum (NGS) for $10 \mathrm{~min}$, followed by incubation for $45 \mathrm{~min}$ at RT with the primary antibody. After three washes of 3 min each in Buffer $A$, the rabbit antibodies were detected by incubation with APase-conjugated swine anti-rabbit IgG (SWAR-APase, diluted 1:25) (Dako), whereas the mouse MAbs were detected with APase-conjugated goat anti-mouse IgG (GAM-APase, diluted 1:25) (Dako), all for $45 \mathrm{~min}$ at RT. All antibodies were diluted in Buffer A containing 2\% NGS. After three washes of 3 min each in PBS, the APase-Fast Red staining reaction was performed as described earlier (Speel et al., 1992b). Polyvinyl alcohol was used to reduce diffusion of the final reaction product (see also Van Noorden and Vogels, 1989; Kiyama and Emson, 1991). In the case of EPLC 65 cells, a final concentration of $5 \mathrm{mM}$ levamisole (Sigma) was added to the reaction medium to inhibit endogenous APase. This was not necessary for the $\mathrm{NCl}-\mathrm{H} 82$ cells. In all cases, control experiments with FITCconjugated secondary antibodies were performed to reproduce the observed APase-Fast Red staining patterns.

\section{Combined ICC and fluorescence ISH}

ICC was always performed before the fluorescence ISH procedure. After APaseFast Red immunostaining of the specific cell protein under investigation, the celis were washed in $0.01 \mathrm{~N} \mathrm{HCl}$ for 2 min at $37^{\circ} \mathrm{C}$, digested with $100 \mu \mathrm{g} / \mathrm{ml}$ pepsin in $0.01 \mathrm{~N} \mathrm{HCl}$ for $20 \mathrm{~min}$ at $37^{\circ} \mathrm{C}$, washed again in $0.01 \mathrm{~N} \mathrm{HCl}$ for $2 \mathrm{~min}$, post-fixed in $1 \%$ paraformaldehyde in PBS for $20 \mathrm{~min}$ at $4^{\circ} \mathrm{C}$, and subjected to the ISH procedure as described above. The FITC-labeled probes could be detected directly, whereas the biotinylated probes were detected by subsequent incubation with amino methyl coumarin acetic acid (AMCA)-conjugated avidin (AvAMCA, diluted 1:100) (Vector, Brunschwig Chemie, Amsterdam, The Netherlands), biotinylated goat anti-avidin (BioGAA, diluted 1:100) (Vector), and again AvAMCA. Fluorescence ISH without a preceding APase-Fast Red immunostaining 
was performed in the same way using one incubation step of FITC-conjugated avidin (AVFITC, diluted 1:500) (Vector) for detection of biotinylated DNA probes.

\section{Simultaneous ICC, fluorescence ISH, and BrdU detection}

BrdU-labeled cells were subjected to APase-Fast Red immunostaining for detection of specific protein constituents and to ISH for detection of DNA targets as described above. The incorporated BrdU was detected by subsequent incubation with monoclonal mouse anti-BrdU (clone IIB5, diluted 1:10) (Schutte et al., 1987), biotinylated horse anti-mouse IgG (BioHAM, diluted 1:200) (Vector), and AVAMCA, with several washing steps in between.

Fluorescence microscopy and confocal scanning laser microscopy

For fluorescence microscopy, cells were embedded in either $0.2 \mathrm{M}$ Tris- $\mathrm{HCl}, \mathrm{pH}$ 7.6 , or PBS, and glycerol $(1: 9 \mathrm{v} / \mathrm{v})$ containing $2 \%$ of the anti-bleaching reagent 1,4-di-azobicyclo-(2,2,2)-octane (DABCO; Sigma). In some cases, either 0.5 $\mu \mathrm{g} / \mathrm{ml}$ of the DNA stain 4',6-diamino-2-phenyl indole (DAPI; Sigma) or Thiazole Orange (TO; Molecular Probes, Eugene, OR, USA) was included in the embedding medium.

Photomicrographs were made with either Fuji 400 ASA or Kodak Tmax 400 ASA films on a Zeiss Axiophot microscope, equipped with a $50 \mathrm{~W}$ mercury arc lamp and appropriate filter sets for red, green, and blue fluorescence.

The BioRad MRC 600 confocal scanning laser microscope (CSLM) imaging system equipped with a krypton/argon mixed-gas laser was used to produce the merged images of the APase-Fast Red staining in combination with the TO counterstaining.

\subsection{Results}

Accuracy and sensitivity of antigen and DNA target localization with the APaseFast Red procedure

Discrete localization of DNA targets and protein epitopes by the red fluorescent APase-Fast Red precipitation product as the final detection step in ISH and ICC could be achieved, by varying the incubation time of this enzyme reaction in a medium with a low substrate concentration and by addition of polyvinyl alcohol, which is generally used to prevent diffusion of the precipitate (Van Noorden and Vogels, 1989; Kiyama and Emson, 1991; Speel et al., 1992b). An enzyme reaction time of $1-5 \mathrm{~min}$ was sufficient for visualization of the DNA probe 
detecting the (sub)centromere region of chromosome 7 in metaphase spreads by ISH (Figure 1A). The cosmid probe specific for a $40 \mathrm{~kb}$ DNA target on the $q$ arm of chromosome 11 could be detected after a 15-min APase-Fast Red enzyme reaction time (Figure $1 \mathrm{~B}$ ). Since preparations were analyzed by CSLM, TO was used as the DNA counterstain, which shows a green fluorescence on exposure to the 488-nm laser line. This dye also emits green light on excitation with blue mercury arc light. The APase-Fast Red procedure was thus shown to be a sensitive method for detection of DNA sequences up to the level of single-copy genes, and is of comparable sensitivity to other fluorescence ISH detection methods.

Similarly, accurate high-resolution images were obtained after APase-Fast Red immunostaining of various cell proteins. For example, cytoplasmic cytokeratin filaments and nuclear constituents, such as the proliferation marker Ki67-Ag, could be localized discretely with a high degree of resolution after an enzyme reaction time of $15 \mathrm{~min}$ (Figures $1 \mathrm{C}$ and 1D). Furthermore, specific APase-Fast Red staining patterns were demonstrated for the nuclear lamins in EPLC 65 cells (data not shown), N-CAM in NCl-H82 cells (Figure 1G; enzyme reaction time 5 $\mathrm{min})$, and the sarcomeric protein titin in heart muscle, resolving a distance of approximately $0.5 \mu \mathrm{m}$ between two titin bands [Speel et al., 1994, BioRad (Richmond, CA, USA) Application Note No. 14]. For detection of cytokeratin filaments and titin, addition of $5 \mathrm{mM}$ levamisole to the reaction medium was essential to inhibit endogenous APase in EPLC 65 and muscle cells. Control experiments were performed with FITC-conjugated secondary antibodies to check the specificity of the primary antibodies used. These stainings were similar to those obtained with the APase-Fast Red reaction (data not shown).

Double-target fluorescence ISH based on the APase-Fast Red reaction and fluorescein-conjugated detection reagents

The APase-Fast Red procedure could be combined with FITC fluorescence detection in a double-target ISH experiment to simultaneously visualize a biotinylated DNA probe next to a digoxigenin-labeled DNA probe in T24 nuclei (Figures 1E and 1F). As a result, three red (APase-Fast Red; trisomy for chromosome 7 centromere) and three green (FITC; trisomy for chromosome 1 centromere) ISH signals were observed by using the filter set for green fluorescence. 
Table 1. Comparison of the frequency of fluorescence ISH signals/nucleus for chromosomes 1,7 , and 17 in single-target ISH and combined ICC/ISH ${ }^{\circ}$.

Cell linel

chromosome probe
Single-target ISH

Signals per nucleus
Combined ICC/ISH

Signals per nucleus $\begin{array}{llll}2 & 3 & 4\end{array}$ 4

\section{EPLC 65}

probe 1

probe 7

probe 17
1

3

4

$\mathrm{NCl}-\mathrm{H} 82$

probe 7 295 3 $2 \quad 92$ 6

'Analysis of one hundred intact and non-overlapping EPLC 65 or $\mathrm{NCl}-\mathrm{H} 82$ nuclei by two independent observers did not result in significantly different results.

Combined ICC with the APase-Fast Red reaction and double-target fluorescence ISH

As mentioned before, in the combined ICC/ISH procedure, ICC was always applied before the ISH step, since in the latter procedure antigen epitopes are destroyed. Since the cytokeratin filaments or N-CAM staining patterns obtained with teuramethylrhodamine isothiocyanate (TRITC)-labeled secondary antibodies in the ICC step were dramatically influenced by the ISH protocol, the APase-Fast Red detection method was utilized in the ICC step before fluorescence ISH. The red fluorescence, resulting from the APase-Fast Red precipitate, was unaffected by the ISH procedure. This is demonstrated in Figure 1G, showing N-CAM being detected simultaneously with FITC-labeled centromeres for chromosome 7, and in Figure $1 \mathrm{H}$, visualizing cytokeratin filaments together with the centromeres of chromosome 1 (AMCA detection) and 17 (FITC detection).

Although enzymatic digestion with pepsin was not essential for positive ISH results after APase Fast Red ICC, the fluorescence intensity of the observed ISH signals was much higher after inclusion of such a pre-treatment step in the 
procedure. Furthermore, hybridization for $1-2 \mathrm{hr}$ at $37^{\circ} \mathrm{C}$ proved to be sufficient for detection of centromere-specific DNA targets, although the hybridization in most experiments was performed overnight at $37^{\circ} \mathrm{C}$.

To determine the influence of the ICC procedure on the observed number of ISH signals/nucleus, the lung cancer cells treated by ICC and ISH were compared with those subjected to single-target fluorescence ISH with the same DNA probes, except that all the probes were biotinylated and were detected with one layer of AvFITC.

Table 1 shows the results of these comparative studies, in which 100 intact, nonoverlapping nuclei were counted for each DNA probe by two independent investigators. The single-target fluorescence ISH results correspond with those observed after performing the combined ICC/ISH method. The APase-Fast Red precipitation reaction, therefore, seems not to influence the results of the subsequent ISH procedure.

\section{Combined APase-Fast Red ICC, fluorescence ISH, and BrdU detection}

BrdU detection is possible after APase-Fast Red-based ICC and fluorescence ISH with the MAb IIB5. BrdU-labeled, methanol-acetone-fixed EPLC 65 cells were first immunostained for either cytokeratin filaments or Ki67-Ag with the APase-Fast Red reaction. After fluorescence ISH with the FITC-labeled probe for the centromere of chromosome 7, MAb IIB5 was applied and detected by subsequent application of BioHAM antibodies and AvAMCA. Figures $1 \mathrm{I}-1 \mathrm{~L}$ show the results of these combined procedures, which allow simultaneous fluorescence detection of three different parameters in the same cell. Trisomy for chromosome 7 was clearly demonstrated in the majority of EPLC 65 cells (Figures 11 and $1 \mathrm{~K}$ ). From a comparison of Figures $1 \mathrm{I}$ and $1 \mathrm{~J}$, it appears as if the BrdU-labeled (S-phase) cells show lower levels of cytokeratin filaments. This is not an artefact of the procedure, since cells containing strongly positive cytokeratin filaments were detected which showed high BrdU incorporation (e.g., Figures $1 \mathrm{l}$ and $1 \mathrm{~J}$, top lefthand corner). The APase-Fast Red staining pattern for Ki67-Ag was consistent with our earlier observations (Verheijen et al., 1989), which showed Ki67-Ag to be located in the nucleoli of interphase cells (Figure $1 \mathrm{~K}$ ). It is obvious that Ki67$\mathrm{Ag}$ is present in both S-phase and BrdU positive cells as well as in non S-phase cells (compare Figures $1 \mathrm{~K}$ and $1 \mathrm{~L}$ ).

In NCI-H82 cells, we were also able to utilize this combined ICC/ISH procedure for simultaneous detection of N-CAM, the human centromere 7 DNA targets, and incorporated $\mathrm{BrdU}$ (data not shown). 
Figure 1. (A) Merged CSLM image of APase-Fast Red fluorescence for the (sub)centromeric region of chromosome 7 in a human lymphocyte metaphase spread, counterstained with TO. (B) Merged CSLM image of APase-Fast Red fluorescence for a cosmid on chromosome 11q23 in a metaphase spread, counterstained with TO. (C) Merged CSLM image of APase-Fast Red staining of cytokeratin filaments in EPLC 65 cells, counterstained with TO. (D) Merged CSLM image of APase-Fast Red fluorescence for the nuclear proliferation marker Ki67-Ag in EPLC 65 cells, counterstained with TO. (E) DNA staining of the same nucleus as in $F$ with DAPI fluorescence. (F) Simultaneous fluorescence detection of the (sub)centromeric regions of chromosome 1 (FITC) and 7 (APase-Fast Red) in T24 cells. (G) Simultaneous fluorescence detection of the cell surface protein N-CAM (APase-Fast Red) and the (sub)centromeric region of chromosome 7 (FITC) in NCl-H82 cells. (H) Simultaneous fluorescence detection of the cytokeratin filaments (APase-Fast Red) and the (sub)centromeric regions of chromosome 1 (AMCA) and 17 (FITC) in EPLC 65 cells. (I-L) Simuitaneous fluorescence detection of specific cellular proteins (APase-Fast Red), the (sub)centromeric region of chromosome 7 (FITC), and incorporated BrdU (AMCA) in EPLC 65 cells. The red APase-Fast Red fluorescence occasionally appears yellow because of co-localization with green ISH signals or saturation of the photographic film. (I) Keratins (APase-Fast Red) and trisomy for centromere 7 (FITC). (J) BrdU detection (AMCA) in the same cells as seen in I. (K) Nuclear proliferation marker Ki67-Ag (APase-Fast Red) and trisomy for centromere 7 (FITC). (L) BrdU detection (AMCA) in the same cells as seen in K. Bars $=5 \mu \mathrm{m}$

\subsection{Discussion}

This report describes the application of the APase-Fast Red enzymatic reaction, resulting in a red fluorescent precipitate, in combined ICC/ISH procedures. Finetuning of the enzyme reaction time, by monitoring the reaction in the microscope, in combination with the use of polyvinyl alcohol to prevent diffusion of the reaction product, resulted in discretely localized $1 \mathrm{SH}$ signals in metaphase chromosome spreads and in interphase nuclei, and in accurate protein localization in cultured tumor cells. Together with the fact that this procedure results in strong fluorescent signals, the advantageous slow-fading properties of the precipitate make the APase-Fast Red reaction highly suitable for sensitive, highresolution enzyme cytochemistry for fluorescence microscopy. The sensitivity of the procedure was demonstrated in resolving the cosmid probe on both chromatids of chromosome 11 (Figure 1B), the cytokeratin filaments in EPLC 65 cells (Figures $1 \mathrm{C}$ and $1 \mathrm{H}$ ), and titin banding in striated heart muscle. TO appeared to be a valuable DNA staining reagent in combination with APase-Fast Red fluorescence, although TO fluorescence was detected to a low extent through the red fluorescence filter set. Therefore, derivatives of TO are now being investigated for their better fluorescent properties in this respect. Use of the APase-Fast Red reaction for ICC proved to be very suitable in combination with $\mathrm{ISH}$, since the precipitated reaction product was stable on pepsin pre-treatment at $\mathrm{pH} 2$ and throughout the entire $1 \mathrm{SH}$ procedure. 

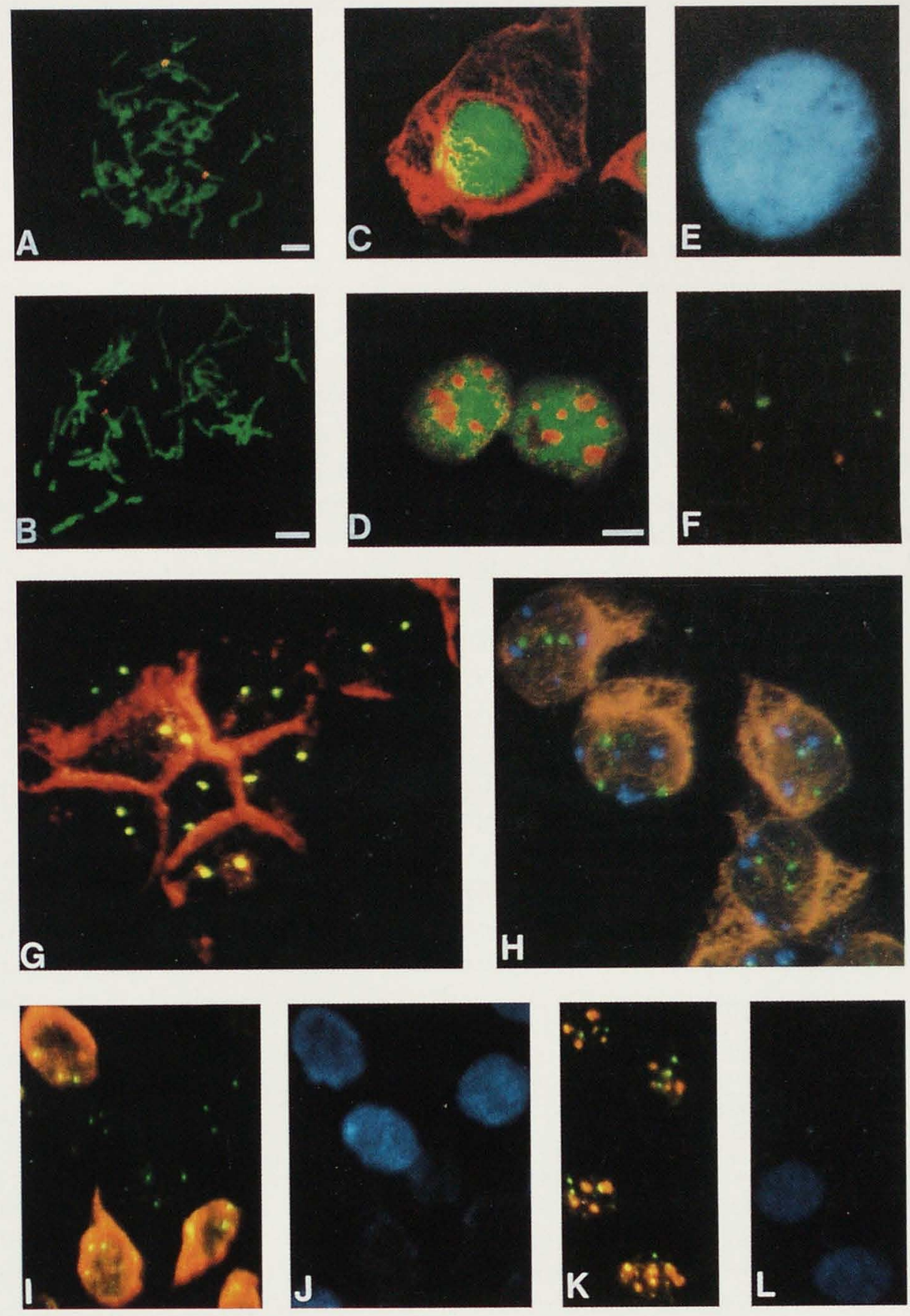
The ISH results on APase-Fast Red immunostained lung cancer cells showed the correct number of ISH signals/nucleus compared with the non-immunostained cells (see Table 1). In colon adenoma cells displaying trisomy for the centromeric region of chromosome 7, we utilized the combined ICC/ISH procedure to demonstrate the epithelial origin of the cells with the numerical chromosome aberration for chromosome 7 (Herbergs et al., 1994). From this, we conclude that the APase-Fast Red reaction product does not make the cells less accessible to ISH reagents and does not shield the target DNA. The latter phenomenon has been shown to occur when the peroxidase-diaminobenzidine reaction is used for the ICC step (Van den Brink et al., 1990; Strehl and Ambros, 1993). Application of the APase-Fast Red reaction has the advantage that directly FITC-labeled, centromere-specific DNA probes can thus be detected without any amplification step (Figures $1 \mathrm{G}-\mathrm{I}$ and $1 \mathrm{~K}$ ), which increases analytical speed and reduces background reactions. Only when AMCA was used as the third fluorochrome were amplification steps needed, since in our hands the blue fluorescence intensity was less than the FITC or Fast Red fluorescence intensity (Figure $1 \mathrm{H}$ ).

The combined ICC/ISH procedure could be extended with the detection of incorporated $\mathrm{BrdU}$, since the heat denaturation step at $70^{\circ} \mathrm{C}$ applied in the $\mathrm{ISH}$ procedure is also suitable for subsequent $\mathrm{BrdU}$ detection with the anti-BrdU antibody. Therefore, three cell parameters can now be analyzed simultaneously in the same cell, using APase-Fast Red for antigen staining, FITC for visualization of a DNA probe, and AMCA for BrdU detection.

The accurate detection of these parameters in the same cell makes this procedure extremely suitable for detection of tumor cell heterogeneity, rare event detection, and in cases where only a few cells can be obtained for analysis (e.g., in aspirate cytology or in biopsy material). Furthermore, in cases where extensive proteolytic digestion for fluorescence ISH is needed (e.g., in paraffin sections that show autofluorescence induced by tissue fixation), ICC based on APase-Fast Red can be advantageous, since enzymatic digestion reduces autofluorescence but not the stable APase-Fast Red signal.

\section{Acknowledgements}

We thank Dr J Askaa (Dako) for the rabbit anti-Ki67-Ag antiserum, Dr EB Lane (University of Dundee, Dundee, UK) for MAb anti-lamin B2, Dr D van Bockstaele (University of Antwerpen, Antwerpen, Belgium) for the DNA stain Thiazole Orange, and Dr B Schutte, M Henfling, and J Derhaag for technical assistence. This work was supported by the Netherlands Organization for Scientific Research NWO, grant no. 900-534-102. 


\subsection{References}

Balazs M, Mayall BH, Waldman FM (1991) Simultaneous analysis of chromosomal aneusomy and 5-bromodeoxyuridine incorporation in MCF-7 breast tumor cell line. Cancer Genet Cytogenet 57:93-102

Boerman OC, Mijnheere EP, Broers JLV, Vooijs GP, Ramaekers FCS (1991) Biodistribution of a monoclonal antibody (RNL-1) against the neural cell adhesion molecule (NCAM) in athymic mice bearing human small-cell lung-cancer xenografts. Int $\mathrm{J}$ Cancer 48:457-462

Broers JLV, Klein Rot M, Oostendorp T, Bepler G, De Leij L, Carney DN, Vooijs GP, Ramaekers FCS (1988) Spontaneous changes in intermediate filament protein expression patterns in lung cancer cell lines. J Cell Sci 91:91-108

Bubeník J, Baresová M, Viklicky V, Jakoubková J, Sainerová H, Donner J (1973) Established cell line of urinary bladder carcinoma (T24) containing tumour-specific antigen. Int J Cancer 11:765-773

Cooke HJ, Hindley J (1979) Cloning of human satellite III DNA: different components are on different chromosomes. Nucleic Acids Res 6:3177-3197

Dirks RW, Van de Rijke FM, Fujishita S, Van der Ploeg M, Raap AK (1993) Methodologies for specific intron and exon RNA localization in cultured celis by haptenized and fluorochromized probes. J Cell Sci 104:1187-1197

Gendelman HE, Moench TR, Narayan O, Griffin DE, Clements JE (1985) A double labeling technique for performing immunocytochemistry and in situ hybridization in virus infected cell cultures and tissues. J Virol Methods 11:93-103

Herbergs J, De Bruïne AP, Marx PTJ, Vallinga MIJ, Stockbrügger RW, Ramaekers FCS, Arends JW, Hopman AHN (1994) Chromosome aberrations in adenomas of the colon. Proof of trisomy 7 in tumor cells by combined interphase cytogenetics and immunocytochemistry. Int $\mathrm{J}$ Cancer 57, 781-785

Kiyama H, Emson PC (1991) An in situ hybridization histochemistry method for the use of alkaline phosphatase-labeled oligonucleotide probes in small intestine. J Histochem Cytochem 39:1377-1384

Larsson L-1, Hougaard DM (1991) Combined non-radioactive detection of peptide hormones and their mRNA's in endocrine cells. Histochemistry 96:375-380 
Losada AP, Wessman M, Tiainen M, Hopman AHN, Willard HF, Solé F, Rosa Caballín M, Woessner S, Knuutila $S$ (1991) Trisomy 12 in chronic lymphocytic leukemia: an interphase cytogenetic study. Blood 78:775-779

Mullink H, Walboomers JMM, Tadema TM, Jansen DJ, Meijer CJLM (1989) Combined immuno- and non-radioactive hybridocytochemistry on cells and tissue sections: influence of fixation, enzyme pre-treatment, and choice of chromogen on detection of antigen and DNA sequences. J Histochem Cytochem 37:603-609

Porter HJ, Heryet A, Quantrill AM, Fleming KA (1990) Combined non-isotopic in situ hybridization and immunohistochemistry on routine paraffin wax embedded tissue: identification of cell type infected by human parvovirus and demonstration of cytomegalovirus DNA and antigen in renal infection. J Clin Pathol 43:129-132

Ramaekers FCS, Puts JJG, Moesker O, Kant A, Huysmans A, Haag D, Jap PHK, Herman CJ, Vooijs GP (1983) Antibodies to intermediate filament proteins in the immunohistochemical identification of human tumours: an overview. Histochem $\mathrm{J}$ 15:691713

Schutte B, Reynders MMJ, Bosman FT, Blijham GH (1987) Studies with antibromodeoxyuridine antibodies: II. Simultaneous immunocytochemical detection of antigen expression and DNA synthesis by in vivo labeling of mouse intestinal mucosa. J Histochem Cytochem 35:371-374

Speel EJM, Schutte B, Ramaekers FCS, Hopman AHN (1992a) The effect of avidin-biotin interactions in detection systems for in situ hybridization. J Histochem Cytochem 40:135141

Speel EJM, Schutte B, Wiegant J, Ramaekers FCS, Hopman AHN (1992b) A novel fluorescence detection method for in situ hybridization, based on the alkaline phosphatasefast red reaction. J Histochem Cytochem 40:1299-1308

Speel EJM, Kamps M, Bonnet J, Ramaekers FCS, Hopman AHN (1993) Multicolour preparations for in situ hybridization using precipitating enzyme cytochemistry in combination with reflection contrast microscopy. Histochemistry 100:357-366

Strehl S, Ambros PF (1993) Fluorescence in situ hybridization combined with immunohistochemistry for highly sensitive detection of chromosome 1 aberrations in neuroblastoma. Cytogenet Cell Genet 63:24-28

Tokino T, Takahashi E, Mori M, Tanigami A, Glaser T, Park JW, Jones C, Hori T, Nakamura 
$Y$ (1991) Isolation and mapping of 62 new RFLP markers on human chromosome 11. Am J Hum Genet 48:258-268

Trembleau A, Roche D, Calas A (1993) Combination of non-radioactive and radioactive in situ hybridization with immunohistochemistry: a new method allowing the simultaneous detection of two mRNAs and one antigen in the same brain tissue section. $J$ Histochem Cytochem 41:489-498

Van Dekken H, Schervish EW, Pizzolo JG, Fair WR, Melamed MR (1991) Simultaneous detection of fluorescent in situ hybridization and in vivo incorporated BrdU in a human bladder tumour. J Pathol 164:17-22

Van den Berg H, Vossen JM, Van den Bergh RL, Bayer J, Van Tol MJD (1991) Detection of $Y$ chromosome by in situ hybridization in combination with membrane antigens by twocolor immunofluorescence. Lab Invest 64:623-628

Van den Brink W, Van der Loos C, Volkers H, Lauwen R, Van den Berg F, Houthoff H, Das PK (1990) Combined $\beta$-Galactosidase and immunogold/silver staining for immunohistochemistry and DNA in situ hybridization. J Histochem Cytochem 38:325-329

Van Noorden CJF, Vogels IMC (1989) Polyvinylalcohol and other tissue protectants in enzyme histochemistry: a consumer's guide. Histochem $\mathrm{J}$ 21:373-379

Verheijen R, Kuijpers HJH, Schlingemann RO, Boehmer ALM, Van Driel R, Brakenhoff GJ, Ramaekers FCS (1989) Ki-67 detects a nuclear matrix-associated proliferation antigen. I. Intracellular localization during interphase. J Cell Sci 92:123-130

Waye JS, Willard HF (1986) Molecular analysis of a deletion polymorphism in alpha satellite of human chromosome 17: evidence for homologous unequal crossing-over and subsequent fixation. Nucleic Acids Res 14:6915-6928

Waye JS, England SB, Willard HF (1987) Genomic organization of alpha satellite DNA on human chromosome 7: evidence for two distinct alphoid domains on a single chromosome. Mol Cell Biol 7:349-356

Weber-Matthiesen K, Deerberg J, Müller-Hermelink A, Schlegelberger B, Grote W (1993) Rapid immunophenotypic characterization of chromosomaliy aberrant cells by the new fiction method. Cytogenet Cell Genet 63:123-125 
Chapter 2

Wolfson B, Manning RW, Davis LG, Arentzen R, Baldino F Jr (1985) Co-localization of corticotropin releasing factor and vasopressin mRNA in neurones after adrenalectomy. Nature 315:59-61 
Combination of lamin immunocytochemistry and in situ hybridization for the analysis of chromosome copy numbers in tumor cell areas with high nuclear density

Jos Herbergs, Ernst JM Speel, Frans CS Ramaekers, Adriaan P de Bruïne, Jan Willem Arends and Anton HN Hopman

Cytometry 23, 1-7, 1996 


\section{Abstract}

We describe the application of lamin immunocytochemistry (ICC) and single- or double-target fluorescence in situ hybridization (FISH) on four $\mu \mathrm{m}$ thick frozen tissue sections as a method to facilitate scoring of aberrant chromosome copy numbers in colonic tumors. Analysis of FISH signals in colon tissue sections is often hampered by overlap and truncation of epithelial nuclei, due to the density of the epithelial cells. Furthermore, on basis of nuclear staining it is often difficult to determine whether or not nuclei are overlapping, or adjoining. Therefore, reliable evaluation of (F)ISH signals to screen for genomic changes was until now mainly restricted to isolated nuclei obtained from relatively thick tissue sections. In this study the applicability of lamin ICC, to stain the nuclear periphery and to distinguish individual nuclei, combined with the FISH procedure is explored to solve this problem for colon epithelium. For ICC we applied the alkaline phosphatase (APase)-Fast Red detection method, since the fluorescent precipitate of this reaction resists extensive proteolytic digestion as needed for efficient FISH on tissue sections.

Chromosome copy numbers could easily be determined in four $\mu \mathrm{m}$ thick frozen tissue sections by combining lamin ICC and FISH. The ratio of the copy numbers of the chromosomes 7 and 17 could be determined in frozen tissue sections after combined lamin ICC and double-target FISH.

It is concluded that the combination of lamin ICC and FISH improves chromosome copy number analysis and can be used to investigate genomic changes in different tumor compartments in thin frozen tissue sections.

\subsection{Introduction}

The fluorescence in situ hybridization (FISH) technique is applied as a tool to investigate numerical and structural chromosome aberrations in solid tumors, either as single cell suspensions, frozen tissue sections or paraffin sections. The evaluation of FISH signals in interphase nuclei of thin sections, however, is hampered by truncation of the nuclei and in some tissues, like colon tumors, also by overlapping of nuclei due to the epithelial cell density. In these cases it is often difficult to distinguish between the individual nuclei and thus to determine accurately the number of FISH signals per single nucleus. In case of colon tumors $\mathrm{FISH}$ is therefore more accurate when applied to single cell suspensions isolated from tissue blocks (Herbergs et al., 1994). However, for the detection of clonal 
heterogeneity in epithelial tumors, it is necessary to detect the aberrant cells within the tissue architecture. For this purpose, use of FISH on tissue sections is therefore preferable.

To solve the problem of FISH signal interpretation in truncated nuclei of sections, several approaches are developed to determine the real chromosome copy number. One approach uses the Chromosome Index (i.e., total number of ISH signals per number of nuclei counted) (Kim et al., 1993; Dhingra et al., 1994). This approach enables the detection of monosomic or tetrasomic cells in cases where these populations make up more than $25 \%$ of the total cell number. Other investigators have used serial sections for analysis of chromosome copy numbers. Emmerich et al. (1989) analyzed only those nuclei that were localized entirely within three subsequent slides. Hopman et al. (1991) estimated the number of chromosome targets and chromosomal imbalances by employing different probes. Alers et al. (1995) detected chromosomal loss and gain by statistical evaluation of probe spot frequency distributions using the KolmogorovSmirnov test. Recently, Thompson et al. (1994) applied FISH to $20 \mu \mathrm{m}$ thick sections followed by analysis using confocal scanning laser microscopy. This approach is however limited for use in routine screening analysis.

In this paper we report a novel approach to solve interpretation problems arising with the evaluation of FISH signals in possible overlapping and truncated nuclei in thin frozen tissue sections. ICC staining of the nuclear contour with a lamin antibody was combined with single- and double-target FISH to determine the FISH signals per individual nucleus.

\subsection{Materials and methods}

\section{Tissue samples}

Fresh tissue samples from 4 patients with colon carcinomas were obtained after surgery and snap frozen in precooled isopentane.

\section{DNA probes and labeling procedures}

Centromere specific probes for human chromosomes 7 and 17 were used (Willard and Waye, 1987). The DNA probes were labeled with either biotin-11-dUTP (ENZO, New York, NY), digoxigenin-11-dUTP, or fluorescein-12-dUTP (Boehringer, Mannheim, Germany) in a standard nick-translation reaction. 


\section{Single cell suspensions}

In order to obtain reference values for the individual chromosome copy numbers, to be compared to the data obtained in the tissue sections of the same cases, single cell suspensions were prepared from $50 \mu \mathrm{m}$ thick sections after pepsin digestion $\left(100 \mu \mathrm{g} / \mathrm{ml}\right.$ pepsin in $0.01 \mathrm{~N} \mathrm{HCl}$ for $15 \min$ at $\left.37^{\circ} \mathrm{C}\right)$. FISH was performed with the centromere specific probes for chromosomes 7 and 17 on single cell suspensions as described before (Herbergs et al., 1994), and 200 nuclei per chromosome probe were analyzed according to criteria described before (Hopman et al., 1991).

\section{Immunocytochemical staining procedures}

The monoclonal antibody LN43 was used to detect lamin B2 (Broers et al., 1993) and was kindly provided by Dr. E.B. Lane (Dundee, U.K). Four $\mu \mathrm{m}$ thick frozen tissue sections were mounted on poly-L-lysine coated slides, air-dried and briefly fixed in methanol for $1 \mathrm{~min}$ at $-20^{\circ} \mathrm{C}$ and in acetone three times for $5 \mathrm{sec}$ at room temperature. The slides were air-dried and washed twice for $5 \mathrm{~min}$ in PBS containing $0.05 \%$ Tween 20 (buffer A), followed by incubation for $45 \mathrm{~min}$ at $37^{\circ} \mathrm{C}$ with the undiluted primary antibody culture supernatant. After two washes of 5 min each with buffer $A$, the antibodies were detected by incubation with alkaline phosphatase conjugated goat anti-mouse IgG (GAM-APase, diluted 1:25 in buffer A; DAKO A/S, Glostrup, Denmark) for $30 \mathrm{~min}$ at $37^{\circ} \mathrm{C}$. After two washes in buffer A (5 min each) APase activity was detected by the Fast Red precipitation reaction (Speel et al., 1992,1994). The standard protocol was performed with staining reagent containing $4 \mathrm{ml} 0.2 \mathrm{M}$ Tris- $\mathrm{HCl}$ buffer, $\mathrm{pH} 8.5$, $5 \%$ poly vinyl alcohol (PVA) (MW 40,000; Sigma, St. Louis, MO), $1 \mathrm{mg}$ naphtolASMX-phosphate (Sigma) in $250 \mu$ buffer without PVA, and $5 \mathrm{mg}$ Fast Red TR salt (Sigma) in $750 \mu$ buffer without PVA. The reaction time was optimized for frozen tissue sections. The reaction was followed under the light microscope and allowed to run for maximally $10 \mathrm{~min}$.

\section{Single- and double-target FISH after immunocytochemistry}

After APase-Fast Red immunostaining of the specific cell protein under investigation, the slides were washed twice for $5 \mathrm{~min}$ in buffer $\mathrm{A}$, digested with $100 \mu \mathrm{g} / \mathrm{ml}$ pepsin in $0.01 \mathrm{~N} \mathrm{HCl}$ for $10 \mathrm{~min}$ at $37^{\circ} \mathrm{C}$ and washed twice for $5 \mathrm{~min}$ in $0.01 \mathrm{~N} \mathrm{HCl}$. Thereafter the FISH procedure was performed as described before (Hopman et al., 1988).

For single-target FISH we applied after immunocytochemical detection of lamin B2 
biotinylated probes which were detected with AvFITC, BioGAA and again AvFITC. The nuclei were counterstained with 4',6-diamidino-2-phenyl indole (DAPl; Sigma).

For double-target FISH FITC-labeled DNA probes were detected by subsequent incubation with mouse anti-FITC (MAFITC, 1:500), FITC-conjugated rabbit antimouse IgG (RAM-FITC, 1:80) and FITC-conjugated swine anti-rabbit IgG (SWARFITC, 1:80)(all from DAKO). Digoxigenin-labeled probes were detected with subsequent detection steps of mouse anti-digoxin (MADig, 1:2000)(Sigma), RAMFITC and SWAR-FITC. The biotinylated probes were detected by subsequent incubation with amino methyl coumarin acetic acid (AMCA)-conjugated avidin (AvAMCA, 1:100)(Vector, Brunschwig Chemie, Amsterdam. The Netherlands), biotinylated goat anti-avidin (BioGAA, 1:100)(Vector), and again AvAMCA.

\section{Evaluation of FISH signals}

The number of FISH signals was counted per lamin positive nucleus in 10 series of 100 nuclei per slide. For double-target FISH without lamin staining the ratio of the FISH signals for chromosome 7 and 17 was determined in 15 areas of about $2500 \mu \mathrm{m}^{2}$. Microphotographs were recorded with the Zeiss Axioskop or with the Metasystem Image Pro System (black and white CCD camera), Fast Red in Red, FITC in green, AMCA and DAPI in blue. The images were printed with a Mitsubishi $\mathbf{S} 3410$ thermo sublimation printer.

\subsection{Results}

FISH results in frozen tissue sections without lamin staining

The tissue pretreatment steps that are needed to guarantee efficient probe hybridization in FISH, result in a considerable overlap between individual nuclei in frozen tissue sections (Fig. 1A). Because of the extent of nuclear overlap, FISH signals in $4 \mu \mathrm{m}$ thick frozen tissue sections can not be assigned properly to individual nuclei, making an evaluation of such FISH preparations questionable.

\section{The APase-Fast Red lamin reaction}

The APase-Fast Red reaction, that was applied for detection of nuclear lamins, resulted in a strongly fluorescent Fast Red precipitate. Lamin detection resulted in staining of the nuclear contours and allowed to distinguish individual nuclei. The optimal reaction time of the APase-Fast Red precipitation for analysis by fluorescence microscopy was $10 \mathrm{~min}$. A longer reaction time resulted in a more 

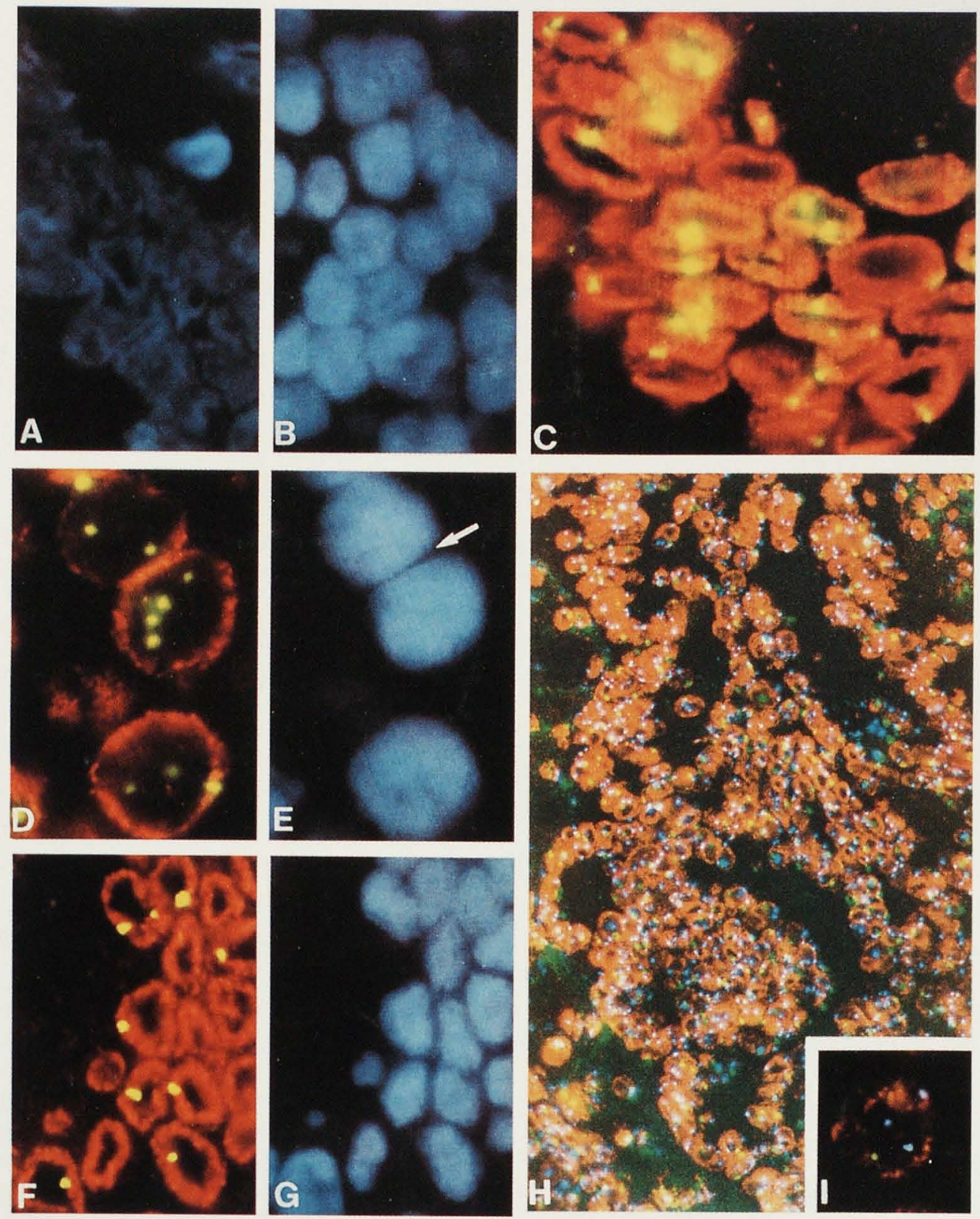
Figure 1. (A-B) DAPI DNA counter staining in $4 \mu \mathrm{m}$ thick frozen tissue sections of colon carcinomas without (A) or with lamin ICC (B). (C-I) Results of combined lamin ICC and single- or double-target FISH on $4 \mu \mathrm{m}$ thick frozen tissue sections of colon carcinomas. (C) Combined ICC for lamin and FISH with a probe for chromosome 7 in colon epithelium classified as normal. (D,E) Combined ICC for lamin and FISH with a probe for chromosome 7 (D) and DAPI DNA counter staining (E) in a tumor area classified as tetrasomic for chromosome 7. The arrow shows stabilization of the nucleus as a result of the Fast-Red precipitate. (F,G) Combined ICC for lamin and FISH with a probe for chromosome 17 (F) and DAPI DNA counter staining (G) in a tumor area classified as monosomic for chromosome 17. (H.I) Combined ICC for lamin and double-target FISH with a probe for chromosome 7 (AMCA, blue) and a probe for chromosome 17 ( FITC, green) in colon epithelium classified as trisomic for chromosome 7 and monosomic for chromosome 17. (A-G. I) Magn. 125x. (H) Magn. 50x.

dense precipitate (Speel et al., 1992), which gave rise to problems with the efficiency of subsequent FISH procedures. The intensity of Fast Red fluorescence and the stability of the precipitate were not reduced after application of the FISH procedures. The nuclear contour staining resulted in less swollen nuclei as compared to nuclei not stained for lamins. As shown in Figure 1B the overlap between nuclei in frozen tissue sections immunocytochemically stained for lamin, was much less than in unstained sections (Fig. 1A).

FISH results in frozen tissue sections with lamin staining Apart from the fact that lamin immunostained nuclei retained their original size also after the FISH procedure, lamin staining with APase-Fast Red revealed also a clear nuclear contour staining and therefore allowed proper distinction of individual nuclei (Fig. 1C,D,F). As a result the number of FISH signals per individual nucleus could now be determined. For example Figure $1 \mathrm{C}$ shows a normal area directly adjacent to the carcinoma, with many nuclei containing two signals for chromosome 7 (indicative for disomy). Figure 1D,E show a tumor area with four signals for chromosome 7 in part of the nuclei (indicative for tetrasomy), while Figure $1 F, G$ show a tumor area with one signal for chromosome 17 in most nuclei (indicative for monosomy). The real chromosome copy number on basis of counting is underestimated as a result of nuclear truncation in the 4 $\mu \mathrm{m}$ thick tissue sections. To determine the reliability of the combined FISH/nuclear contour staining procedure, the following analyses were made:

1) Comparison of FISH results in sections and in suspensions of single nuclei. FISH results on lamin stained $4 \mu \mathrm{m}$ thick sections were correlated to the estimations of spot numbers for individual chromosomes in suspensions of single nuclei prepared from a $50 \mu \mathrm{m}$ thick section of the same sample. In the latter, the effect of truncation is largely absent. For this purpose we selected four colon 
Table 1. Evaluation of FISH results with centromere specific probes for chromosomes 17 and 7 in intact nuclei isolated from $50 \mu \mathrm{m}$ thick sections of colon carcinomas, and in $4 \mu \mathrm{m}$ thick sections of colon carcinomas with or without lamin ICC.

\begin{tabular}{|c|c|c|c|c|}
\hline \multirow[t]{2}{*}{ Case } & \multirow{2}{*}{$\begin{array}{l}\text { Probe } \\
\mathrm{nr}\end{array}$} & \multicolumn{3}{|c|}{ Mean nr of signals per nucleus \pm SD } \\
\hline & & $\begin{array}{l}\text { FISH on isolated nuclei } \\
\text { from } 50 \mu \mathrm{m} \text { sections }\end{array}$ & $\begin{array}{l}\text { FISH on } 4 \mu \mathrm{m} \text { frozen } \\
\text { tissue sections without } \\
\text { lamin ICC }\end{array}$ & $\begin{array}{l}\text { FISH on } 4 \mu \mathrm{m} \text { frozen } \\
\text { tissue sections with } \\
\text { lamin ICC }\end{array}$ \\
\hline 1 & 17 & $\begin{array}{l}1.6 \pm 0.5 \\
\text { (monosomy } 42 \% \text { /disomy } 53 \% \text { ) }\end{array}$ & not evaluable & $0.8 \pm 0.2$ \\
\hline 2 & 17 & $\begin{array}{l}2.0 \pm 0.4 \\
\text { (disomy } 83 \% \text { ) }\end{array}$ & not evaluable & $1.3 \pm 0.1$ \\
\hline 3 & 7 & $\begin{array}{l}2.6 \pm 0.5 \\
\text { (disomy } 38 \% / \text { trisomy } 56 \% \text { ) }\end{array}$ & not evaluable & $1.9 \pm 0.3$ \\
\hline 4 & 7 & $\begin{array}{l}3.1 \pm 1.0 \\
\text { (disomy } 42 \% \text { /tetrasomy } 49 \% \text { ) }\end{array}$ & not evaluable & $2.6 \pm 0.2$ \\
\hline
\end{tabular}

carcinoma samples with an evident monosomy for chromosome 17 (case 1; 42\% of the nuclei), disomy for chromosome 17 (case 2; $83 \%$ of the nuclei), trisomy for chromosome 7 (case 3; $56 \%$ of the nuclei) or tetrasomy for chromosome 7 (case $4 ; 49 \%$ of the nuclei). As expected, the mean number of FISH signals found in the sections with combined lamin staining is lower as compared to the results in the suspensions, due to truncation of nuclei. The results of this comparison are summarized in Table 1. When comparing these results it should be kept in mind that the results of the nuclear suspensions are biased by admixture of nuclei from normal stromal cells. In contrast, the results for the tissue sections were obtained by screening selected tumor areas.

2) Comparison of frequency distributions of FISH signals in sections and in suspensions of single nuclei. The FISH signal frequency distributions of the analyzed nuclei in $4 \mu \mathrm{m}$ thick sections, as well as in suspensions, are compared to each other in Figure 2. From this figure it is obvious that an underestimation of the real chromosome copy number occurs in the $4 \mu \mathrm{m}$ thick sections as a result of truncation of the nuclei. These frequency distribution patterns, however, are in accord with earlier observations of ISH studies on 4 to $6 \mu \mathrm{m}$ thick tissue sections (Hopman et al., 1991, Pahlplatz et al., 1995). From this figure it becomes particularly obvious that an apparent down shift of the number of signals is seen when comparing results from sections to these obtained in the suspensions of 
A

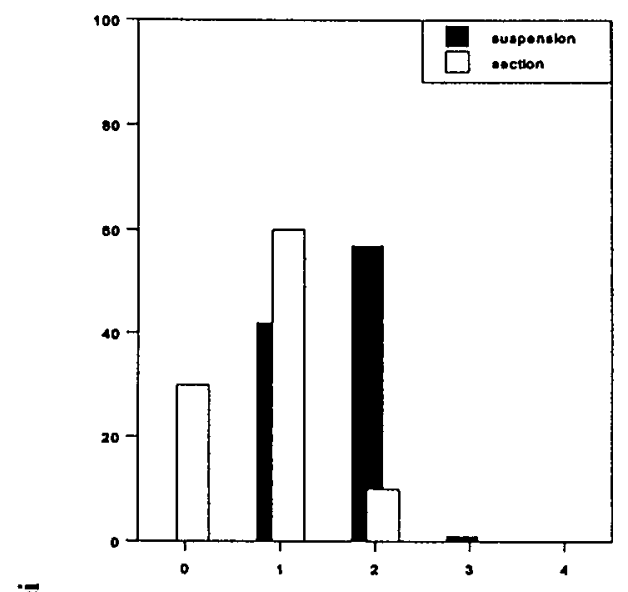

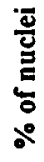

C

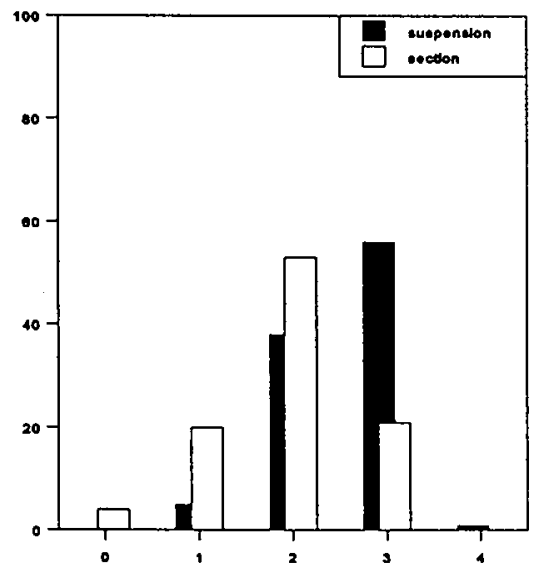

B

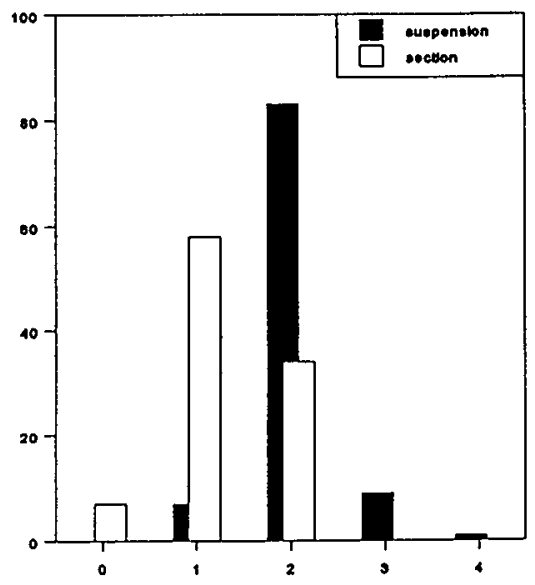

D

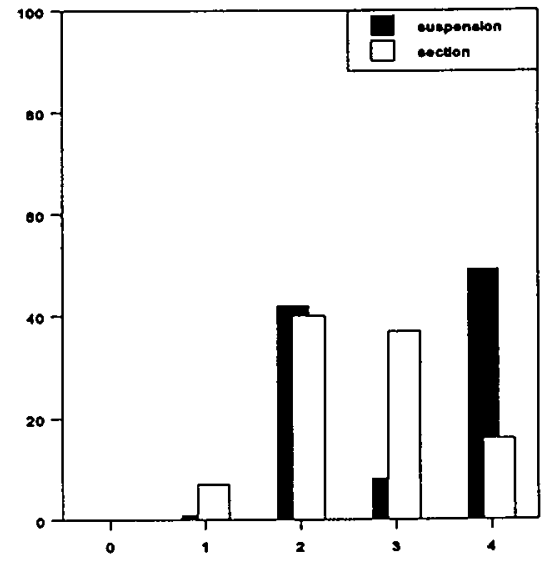

Number of FISH signals

Figure 2. Comparison of frequency distributions of FISH signals for chromosomes 17 or 7 in isolated nuclei (solid bars) and tissue sections (open bars)(see also Table 1).

single nuclei.

Nucl aar lamin ICC with double-target FISH

For combined lamin ICC and double-target FISH (Fig. 1H,I) a chromosome 7: 
chromosome 17 ratio of $1.0 \pm 0.1$ was found in areas with disomy for chromosome 7 and disomy for chromosome 17. In areas with a trisomy for chromosome 7 and monosomy for chromosome 17 this ratio was $2.9 \pm 0.4$. When double-target FISH was performed on these sections without preceding lamin staining the average ratios were $1.0 \pm 0.1$ and $2.9 \pm 0.2$, respectively. These are, however, results obtained by counting the number of FISH signals for the individual chromosomes in a tumor area. In this latter case no information is obtained about the number of FISH signals per individual nucleus.

\subsection{Discussion}

ISH on tissue sections is increasingly used to detect genetic aberrations in solid tumors. However, accurate analysis of the absolute number of ISH signals is hampered by truncation of the nuclei, although an estimate of the chromosome copy number can be made on the basis of hybridization of serial sections, references within the tissue sections itself, and after mathematical correction (Hopman et al., 1991; Kim et al., 1993, Pahlplatz et al., 1995). In some (pre)malignancies, such as colonic and cervical tumors, an additional problem is introduced by the overlap of the epithelial nuclei, due to the cell density, which makes it difficult to distinguish the individual nuclei, even in $4 \mu \mathrm{m}$ thick sections. This problem is enhanced when these samples have undergone the proteolytic pretreatment steps needed for the ISH procedure, resulting in an even fuzzier appearance of the nuclei. In this paper a novel approach is reported to partly overcome these problems.

We applied the sensitive APase-Fast Red reaction for ICC staining of lamins, which allows a combination with ISH, since the Fast Red precipitate is resistant to the extensive enzymatic digestion step, necessary for the reduction of autofluorescence and to allow penetration of DNA probes and antibodies. Lamin immunostaining with APase-Fast Red leads to an apparent stabilization of the nucleus, presumably as a result of physical trapping of the DNA within an artificial matrix (Fig. 1E, arrow). As a result the extent of nuclear overlap in the final ISH preparation is drastically decreased. Furthermore, this protein-Fast Red matrix allows an even more rigorous proteolytic pretreatment of the tissue, resulting in a more efficient ISH reaction. Adjoining nuclei in such lamin stained preparations, that could not be distinguished with DAPI-counter staining, could be seperately recognized by the contour staining of lamins and evaluation of these individual nuclei was therefore improved. Taking together, staining for lamin makes it 
possible to analyze tumor sections by ISH that could otherwise not be evaluated. Also it allows the analysis of individual nuclei, by which genome heterogeneity can be detected in tumor samples.

Although we can now accurately analyze the number of FISH signals in thin frozen tissue sections of colon carcinomas, the results do not always provide the true chromosome copy number, since truncation of nuclei occurs. By counting several fields of approximately 100 nuclei we could obtain a reasonable estimate of the true copy number for individual chromosomes. We can thus detect chromosome aberrations in tissue sections, although the detected deviations are always less prominent as compared to the results obtained in suspensions of single nuclei. The results are always an underestimation of the real chromosome copy numbers. The extent of deviation from the real copy number decreases with the thickness of the tissue section, but as a result nuclear overlap will increase. To obtain a balance between these two phenomena we chose to use $4 \mu \mathrm{m}$ thick sections in case of colon carcinomas. It might well be that for the analysis of other tumor types thicker sections can be used. To determine the absolute chromosome copy number, even thicker sections should be analyzed using confocal laser scanning microscopy (Thompson et al., 1994).

In another approach to determine chromosome imbalances in colon tumor tissue sections, we peformed double-target FISH with and without lamin staining. In double-target FISH without lamin staining, only an average chromosome ratio after evaluation of areas of (overlapping) nuclei can be determined, but not the chromosome ploidy. To obtain more precise information about the chromosomal content per nucleus, combined lamin staining with double-target FISH is therefore preferable. What remains to be incorporated into this approach is the phenotyping of the aberrant cell type, e.g., by means of differentiation markers. Compared with other methods used for the detection of chromosomal aberrations in sections (Emmerich et al., 1989; Hopman et al., 1991; Kim et al., 1993; Dhingra et al., 1994), the procedure described in this paper has the major advantage that in one section the chromosome copy number, as well as chromosome imbalances can be detected.

We conclude that combined ICC detection of nuclear lamin and single- or doubletarget FISH allow a more accurate estimation of chromosome copy numbers in thin frozen tissue sections. The method is of particular help in (tumor) tissue with densely packed nuclei. 


\section{Acknowledgments}

We would thank Dr E.B. Lane for kindly providing MAb anti-lamin B2, Dr. C.E.M. Voorter for assistance with the Metasystem Image Pro System and Metasystems Hard \& Software Gmbh (Sandhausen, Germany) for printing the images.

\subsection{References}

Alers JC, Krijtenburg PJ, Vissers KJ, Bosman FT, Van der Kwast TH, Van Dekken H (1995) Interphase cytogenetics of prostatic adenocarcinoma and precursor lesions: Analysis of 25 radical prostatectomies and 17 adjacent prostatic intraepithelial neoplasias. Genes Chromosom Cancer 12:241-250

Broers JLV, Raymond Y, Klein Rot M, Kuijpers H, Wagenaar SS, Ramaekers FCS (1993) Nuclear A-type lamins are differentially expressed in human lung cancer subtypes. Am $J$ Path 143:211-220

Dhingra K, Sneige N, Pandita TK, Johnston DA, Lee JS, Emami K, Hortobagyi GN, Hittelman WN (1994) Quantitative analysis of chromosome in situ hybridization signal in paraffin-embedded tissue sections. Cytometry 16:100-112

Emmerich P, Jauch A, Hofmann M-C, Cremer T, Walt H (1989) Interphase cytogenetics in paraffin embedded sections from human testicular germ cell tumor xenografts and in corresponding cultured cells. Lab Invest 61:235-242

Herbergs J, De Bruïne AP, Marx PTJ, Vallinga MIJ, Stockbrügger RW, Ramaekers FCS, Arends JW, Hopman AHN (1994) Chromosome aberrations in adenomas of the colon. Proof of trisomy 7 in tumor cells by combined interphase cytogenetics and immunocytochemistry. Int J Cancer 57:781-785

Hopman AHN, Ramaekers FCS, Raap AK, Beck JLM, Devilee P, Van der Ploeg M, Vooijs GP (1988) In situ hybridization as a tool to study numerical chromosome aberrations in solid bladder tumors. Histochemistry 89:307-316

Hopman AHN, Van Hooren E, Van de Kaa CA, Vooijs PGP, Ramaekers FCS (1991) Detection of numerical chromosome aberrations using in situ hybridization in paraffin sections of routinely processed bladder cancers. Mod Path 4:503-513

Kim SY, Lee JS, Ro JY, Gay ML, Hong WK, Hittelman WN (1993) Interphase cytogenetics in paraffin sections of lung tumors by non-isotopic in situ hybridization. Mapping genotype/phenotype heterogeneity. Am J Path 142:307-317 
Pahlplatz MMM, De Wilde PCM, Poddighe P, Van Dekken H, Vooijs GP, Hanselaar AGJM (1995) A model for evaluation of in situ hybridization spot count distributions in tissue sections. Cytometry 20:193-202

Speel EJM, Schutte B, Wiegant J, Ramaekers FCS, Hopman AHN (1992) A novel fluorescence detection method for in situ hybridization, based on the alkaline phosphataseFast Red reaction. J Histochem Cytochem 40:1299-1308

Speel EJM, Herbergs J, Ramaekers FCS, Hopman AHN (1994) Combined immunocytochemistry and fluorescence in situ hybridization for simulaneous tricolor detection of cell cycle, genomic, and phenotypic parameters of tumor cells. $J$ Histochem Cytochem 42:961-966

Thompson CT, LeBoit PE, Nederlof PM, Gray JW (1994) Thick-section fluorescence in situ hybridization on formalin-fixed, paraffin-embedded archival tissue provides a histogenetic profile. Am J Path 144:237-243

Willard HF, Waye JS (1987) Hierarchical order in chromosome-specific human alpha satellite DNA. Trends Genet 3:192-198 
Chromosome aberrations in adenomas of the colon. Proof of trisomy for chromosome 7 in tumor cells by combined interphase cytogenetics and immunocytochemistry

Jos Herbergs, Adriaan $P$ de Bruïne, Patrick TJ Marx, Monique IJ

Vallinga, Reinhold W Stockbrügger, Frans CS Ramaekers, Jan Willem Arends and Anton HN Hopman

Int J Cancer 57, 781-785, 1994 


\section{Abstract}

Thirty-five colon adenomas from 26 patients were analyzed with centromeric probes for the chromosomes $1,7,17, X$ and $Y$ in order to study numerical aberrations, chromosome imbalances, aneuploidy and tetraploidization. The fluorescent in situ hybridization (FISH) technique was applied to single-cell suspensions and a combination of FISH and immunocytochemistry (ICC) was employed to identify the cell type under study.

Trisomy for chromosome 7 was detected in $37 \%$ of the cases. In 7 out of 13 cases this aberration was combined with abnormalities of one or two of the other investigated chromosomes.

No correlation could be demonstrated between any of the detected chromosomal aberrations and size, localization or degree of epithelial dysplasia. With the combined FISH/ICC procedure, the abnormal cells were shown to be of epithelial rather than of stromal origin.

Our data indicate that trisomy for chromosome 7 is a common chromosome aberration in the epithelial component of colon adenomas.

\subsection{Introduction}

Non-random chromosomal abnormalities have been observed in many types of human solid tumors (Sandberg, 1990). Most information on the genomic changes is acquired by karyotyping analysis of solid tumor cultures, but in recent years the fluorescent in situ hybridization (FISH) procedure has been used for targeted analyses of numerical chromosome abnormalities within interphase nuclei of (pre) malignancies.

In many different tumor types, including colorectal adenocarcinomas (Muleris et al., 1990; Bardi et al., 1993), trisomy for chromosome 7 is a frequently found abnormality. In many of these neoplasms, trisomy for chromosome 7 was the sole chromosomal aberration detected and was therefore interpreted as a primary change in cancer development. Recent studies, however, suggest that trisomy for chromosome 7 does not occur in the tumor cells, but in non-malignant stromal cells. Cytogenetic analyses of short-term cultures from colorectal adenocarcinomas (Bardi et al., 1991) showed trisomy for chromosome 7 in fibroblast-like cells. Trisomy for chromosome 7 was also found by cytogenetic analyses of short-term cultures of tumor-surrounding kidney tissue (Casalone et al., 1992) and from studies using a combination of FISH and 
immunocytochemistry (ICC) to characterize subpopulations of tumor-infiltrating lymphocytes in kidney tumors and apparently normal kidney tissue (Dal Cin et al., 1992).

Additional evidence supporting this notion is the presence of trisomy for chromosome 7 in some non-malignant conditions, as in non-neoplastic human brain tissue (Heim et al., 1989) and normal lung tissue (Lee et al., 1987). Furthermore, trisomy for chromosome 7 was detected by cytogenetic analyses of short-term cultures in precursors of malignant tumors, as in several reports concerning colonic adenomas (Longy et al., 1990; Williams et al., 1992).

To detect a possible role of trisomy for chromosome 7 in cancer development and the cell type involved, we analyzed colonic adenomas for the occurrence of trisomy for chromosome 7 and characterized the aberrant cells. For this purpose, we performed interphase cytogenetics using the FISH procedure to detect chromosome 7 aberrations in combination with the immunocytochemical detection of cytokeratin 18, to identify the cell type. Furthermore, as an indicator of overall chromosomal ploidy, we used a centromeric DNA probe for chromosome 1 , because numerical aberrations for this chromosome are rarely found in colorectal adenomas and adenocarcinomas (Muleris et al., 1990). The centromeric probe for chromosome 17 was used since loss of chromosome 17 has been reported by other investigators in colorectal adenocarcinomas (Muleris et al., 1990; Bardi et al., 1993), and the sex chromosomes $X$ and $Y$ were detected since they are frequently involved in early stages of malignant transformation in various tumor types (Sandberg, 1990).

\subsection{Materials and methods}

\section{Tissues}

Fresh tissue of polyps from 28 patients was obtained after endoscopy and small blocks (maximum size $3 \mathrm{~cm}$ ) were snap frozen in precooled isopentane. Table 1 summarizes the clinical data of the patients and the relevant histological data of the tissues. In one case (case 18), 7 adenomas were found.

In addition, 10 samples of normal colonic epithelium were obtained after endoscopy and analyzed in parallel with the adenomas.

\section{Sample preparation}

Fresh tissue of 38 polyps from 28 patients was divided into 2 parts, one for histopathology and one for FISH. For FISH we used single-cell suspensions, 
Table 1. Classification of adenomas according to age and sex, size, growth pattern and degree of dysplasia

\begin{tabular}{|c|c|c|c|c|}
\hline $\begin{array}{l}\text { Case } \\
\text { number }\end{array}$ & Age/sex & $\begin{array}{c}\text { Diameter } \\
\text { (mm) }\end{array}$ & Growth pattern & $\begin{array}{l}\text { Degree of } \\
\text { dysplasia' }\end{array}$ \\
\hline 1 & $70 / \mathrm{F}$ & 12 & tubular & ++ \\
\hline $2 a$ & $64 / F$ & 7 & tubular & ++ \\
\hline $2 b$ & $64 / F$ & 9 & villous & ++ \\
\hline 3 & $66 / F$ & 24 & tubular & +++ \\
\hline 4 & $53 / \mathrm{M}$ & 21 & tubular & ++ \\
\hline 5 & $55 / F$ & 17 & tubular & ++ \\
\hline 6 & $83 / F$ & 7 & tubulovillous & ++ \\
\hline 7 & $75 / M$ & 8 & tubular & ++ \\
\hline 8 & $79 / F$ & 16 & tubulovillous & +++ \\
\hline 9 & $38 / \mathrm{M}$ & 21 & hyperplastic & ND \\
\hline 10 & $78 / \mathrm{M}$ & 8 & tubular & ++ \\
\hline 11 & $67 / M$ & 13 & tubular & ++ \\
\hline 12 & $92 / M$ & 10 & tubulovillous & ++ \\
\hline 13 & $60 / \mathrm{M}$ & 33 & tubular & +++ \\
\hline 14 & $46 / F$ & 22 & tubular & ++ \\
\hline 15 & $44 / F$ & 8 & tubular & + \\
\hline 16 & $50 / \mathrm{M}$ & 13 & villous & +++ \\
\hline 17 & $50 / \mathrm{M}$ & 13 & tubular & ++ \\
\hline $18 a$ & $55 / M$ & 4 & tubular & ++ \\
\hline $18 b$ & $55 / M$ & 12 & tubular & ++ \\
\hline $18 \mathrm{c}$ & $55 / \mathrm{M}$ & 7 & tubular & ++ \\
\hline $18 d$ & $55 / M$ & 12 & tubulovillous & ++ \\
\hline $18 \mathrm{e}$ & $55 / M$ & 10 & tubular & +++ \\
\hline $18 f$ & $55 / M$ & ND & tubular & ++ \\
\hline $18 g$ & $55 / M$ & 4 & tubular & ++ \\
\hline 19 & $78 / \mathrm{M}$ & 8 & tubular & ++ \\
\hline 20 & $10 / \mathrm{F}$ & 30 & hyperplastic & ND \\
\hline 21 & $71 / F$ & 15 & tubular & +++ \\
\hline 22 & $68 / M$ & 16 & tubular & + \\
\hline 23 & $70 / \mathrm{M}$ & 12 & tubular & + \\
\hline 24 & $M$ & ND & tubular & + \\
\hline $25 a$ & $73 / \mathrm{M}$ & 14 & tubular & + \\
\hline $25 b$ & $73 / M$ & 9 & tubular & ++ \\
\hline 26 & $61 / M$ & 8 & tubular & ++ \\
\hline $27 a$ & $79 / M$ & 7 & tubulovillous & ++ \\
\hline $27 b$ & $79 / M$ & 11 & tubular & ++ \\
\hline $28 a$ & $55 / \mathrm{M}$ & 8 & hyperplastic & ND \\
\hline $28 \mathrm{~b}$ & $55 / M$ & 13 & tubular & ++ \\
\hline
\end{tabular}

'Degree of dysplasia: $+=$ mild, $++=$ moderate,$+++=$ severe; ND not done 
paraffin-embedded tissue, and frozen tissue. Single-cell suspensions were prepared by mincing tissue blocks of fresh adenomas. For isolation of epithelial cells the minced tissue blocks were treated with phosphate buffered saline (PBS) containing $1 \mathrm{mM}$ ethylenediamine-tetraacetic acid (EDTA; Merck, Darmstadt, Germany), $1 \mathrm{mM}$ ethyleneglycol-bis-(B-amino ethyl ether)-N,N,N', N'-tetraacetic acid (EGTA; Sigma, St Louis, MO) and $0.5 \mathrm{mM}$ dithiothreitol (DTT; Sigma). The cells were fixed in $70 \%$ ethanol at $-20^{\circ} \mathrm{C}$ (Whitehead et al., 1987).

prepared by mincing tissue blocks of fresh adenomas. For isolation of epithelial cells the minced tissue blocks were treated with phosphate buffered saline (PBS) containing $1 \mathrm{mM}$ ethylenediamine-tetraacetic acid (EDTA; Merck, Darmstadt, Germany), $1 \mathrm{mM}$ ethyleneglycol-bis-(B-amino ethyl ether)-N,N,N', N'-tetraacetic acid (EGTA; Sigma, St Louis, MO) and $0.5 \mathrm{mM}$ dithiothreitol (DTT; Sigma). The cells were fixed in $70 \%$ ethanol at $-20^{\circ} \mathrm{C}$ (Whitehead et al., 1987).

\section{Tumor cell processing}

Five microliters of the single-cell suspensions were dropped onto poly-L-lysine (Mw. 150,000; Sigma) coated slides and air dried. A proteolytic digestion step was performed with pepsin from porcine stomach mucosa $2,500-3,500$ units per $\mathrm{mg}$ protein; Sigma) at a concentration of $100 \mu \mathrm{g} / \mathrm{ml}$ in $0.01 \mathrm{~N} \mathrm{HCl}$ for $20 \mathrm{~min}$ at $37^{\circ} \mathrm{C}$. After subsequent dip washes in double-distilled water (5 times) and PBS (5 times), the nuclei were post-fixed in 1\% formaldehyde in PBS for 20 min at $4^{\circ} \mathrm{C}$. The slides were subsequently washed in PBS (5 times) and double-distilled water (5 times), and equilibrated in 60\% formamide-2xSSC (Standard Saline Citrate; Merck), $\mathrm{pH} 7.0$, for $5 \mathrm{~min}$ at room temperature.

\section{DNA probes}

For detection of the target sequences on chromosomes $1,7,17, \mathrm{X}$ and $\mathrm{Y}$, the plasmid probes were used (Willard and Waye, 1987). The probes were labeled by nick-translation with biotin 11-dUTP (Sigma) according to the supplier's instructions. The probes were hybridized in $60 \%$ formamide-2xSSC, $10 \%$ dextran sulfate (Sigma) and $1 \mu \mathrm{g} / \mu \mathrm{i}$ salmon sperm DNA (Sigma) as carrier DNA, at a probe concentration of 2 to $6 \mathrm{ng} / \mu \mathrm{l}$ hybridization mixture. Under these stringency conditions, hybridization to minor binding sites was avoided.

\section{Fluorescence in situ hybridization}

Ten microliters of the hybridization mixture were added to the slides under a coverslip $(18 \times 18 \mathrm{~mm})$. Denaturation was performed at $80^{\circ} \mathrm{C}$ on a heating plate 
in a moist chamber for $4 \mathrm{~min}$. Hybridization was then performed overnight at $37^{\circ} \mathrm{C}$. Next, the slides were washed twice for $5 \mathrm{~min}$ in $60 \%$ formamide- $2 \times S S C$, $\mathrm{pH} 7.0$, at $42^{\circ} \mathrm{C}$ and subsequently twice in $2 \times S S C, \mathrm{pH} 7.0$, for 5 min at $42^{\circ} \mathrm{C}$ and in the same buffer for $5 \mathrm{~min}$ at room temperature. Immunochemical detection was performed as previously described (Pinkel et al., 1988). Nuclei were counter stained with propidium iodide (PI, Sigma) or with 4',6-diamidino-2-phenylindole (DAPI, Sigma). Evaluation of the preparations was performed by counting approximately 200 nuclei per slide, according to criteria described earlier (Hopman et al., 1988).

\section{Combining ICC and FISH}

Ten microliters of the single-cell suspensions were brought to $200 \mu 170 \%$ ethanol and cytospun ( $5 \mathrm{~min}, 1,200 \mathrm{rpm}$ ) onto poly-L-lysine coated slides, air dried and washed in PBS. The monoclonal antibody RCK 106, directed against cytokeratin 18, was used to select for epithelial cells (Ramaekers et al., 1987). After washing with PBS, incubation with RAM-AP 1 $1: 80$ in 2\% normal goat serum, PBS-Tween $0.05 \%$ ) and another washing step with PBS, the APase activity was demonstrated using a fluorescence azo-dye coupling technique. We used a stain solution containing $4 \mathrm{ml}$ of $0.2 \mathrm{M}$ Tris/ $/ \mathrm{HCl}$ buffer, $\mathrm{pH} 8.5$, with $5 \%$ polyvinyl alcohol (PVA) (40 kDa, Sigma), $1 \mathrm{mg}$ of Naphtol-ASMX-phosphate (Sigma) in 250 $\mu /$ buffer without PVA and $5 \mathrm{mg}$ of Fast Red-TR salt (Sigma) in $750 \mu$ buffer without PVA (Speel et al., 1992). This staining solution was then gently mixed and used immediately. The slides were incubated with $100 \mu \mathrm{l}$ staining solution under a coverslip for $30 \mathrm{~min}$ at room temperature and then washed 3 times with PBS for $5 \mathrm{~min}$ at room temperature and air- dried. Next, FISH was performed as described above, using the plasmid probe for the centromeric region of chromosome 7.

\subsection{Results}

Isolation of epithelial cells

To validate the isolation procedure of cells from adenomas (Whitehead et al., 1987), which has been reported to yield a suspension of mainly epithelial cells, we performed immunocytochemical staining procedures for cytokeratin 18 with RCK 106 (Ramaekers et al., 1987) on all suspensions made, in order to detect epithelial cells exclusively. In all these cases approximately $80 \%$ of the cells in suspension were cytokeratin-18-positive. The remaining cytokeratin-18-negative 
Table 2. Numerical aberrations for chromosomes $1,7,17, X$ and $Y$ in colonic adenomas

\begin{tabular}{|c|c|c|c|c|c|}
\hline \multirow{2}{*}{$\begin{array}{c}\text { Case } \\
\text { number }\end{array}$} & \multicolumn{5}{|c|}{ Numerical chromosome aberrations } \\
\hline & Chr. 1 & Chr. 7 & Chr. 17 & Chr. X & Chr. Y \\
\hline 4 & & trisomy & & & \\
\hline 5 & & trisomy & & & \\
\hline 13 & & trisomy & & & \\
\hline 14 & trisomy & tri/tetrasomy & trisomy & tri/tetrasomy & \\
\hline 15 & & trisomy & trisomy & trisomy & \\
\hline 16 & & & & & disomy \\
\hline $18 a$ & & trisomy & & & \\
\hline $18 b$ & & trisomy & trisomy & & \\
\hline $18 d$ & trisomy & trisomy & trisomy & disomy & disomy \\
\hline $18 f$ & & trisomy & & & \\
\hline 19 & & trisomy & & & \\
\hline 21 & mono/trisomy & tri/tetrasomy & & & \\
\hline 22 & trisomy & trisomy & & & \\
\hline $27 a$ & trisomy & tri/tetrasomy & tri/tetrasomy & disomy & disomy \\
\hline
\end{tabular}

cells comprised the stromal and inflammatory cells.

\section{FISH reaction}

The optimal procedure for proteolytic digestion of nuclei and cells with pepsin was first tuned with different concentrations of pepsin in $0.01 \mathrm{~N} \mathrm{HCl}$. A concentration of $100 \mu \mathrm{l} / \mathrm{ml}$ pepsin in $0.01 \mathrm{~N} \mathrm{HCl}$ for $15 \mathrm{~min}$ at $37^{\circ} \mathrm{C}$ gave the best results. The standard procedure for FISH, as described above, was succesfully applied to all suspensions. In all cases the protocol resulted in FISH signals that could be evaluated according to the criteria as described before (Hopman et al., 1988).

\section{Evaluation of FISH results in normal colon}

FISH on 10 samples of endoscopically and histologically normal-looking colon, present in tissue resections from patients with carcinoma, showed no aberration for chromosomes $1,7,17$ or $\mathrm{Y}$. Only one tissue sample from a male patient showed disomy for chromosome $X$. 
Evaluation of FISH results in adenomas

Counting and evaluation of the FISH signals for chromosomes $1,7,17, X$ and $Y$ (Table 2), revealed at least one numerical chromosome aberration in 14 out of 35 adenomas (40\%). In Table 2 we have listed only those cases in which a numerical chromosome aberration was detected. The percentage of aberrant cells found within the samples summarized in this table ranged from $15 \%$ to $70 \%$ [the average percentage of the cells with trisomy for chromosome 7 was $32 \%(n=14$; SD 23); the average percentage of the cells considered as disomic (normal) for chromosome 7 was $4.5 \%(n=21$; SD 3.4$)]$. In 13 out of the 14 cases only a chromosome gain was detected. The most striking observation was that in 13 out of 14 cases showing genomic changes, a trisomy for chromosome 7 was detected. Other changes mostly consisted of trisomy or tetrasomy for chromosomes 1 and 17, disomy, trisomy, and in one case even tetrasomy for chromosome $X$ and disomy for chromosome $Y$. In only one case (case 21 ) did we observe a loss of chromosome 1 . Figure $1(A, B)$ depicts some typical examples of a trisomy for chromosome 7 .

A representive schematic overview of the distribution pattern of the different chromosomes in the case of an adenoma with trisomy for chromosome 7 in $70 \%$ of the nuclei (case 13) is shown in Figure 2A. An example of such a distribution in an adenoma with numerical chromosome aberrations detected for all the investigated chromosomes (case 18d) is shown in Figure 2B. The numerical chromosome aberrations detected in case $18 \mathrm{~d}$ comprised a trisomy for chromosomes 1,7 and 17 and a disomy for chromosomes $X$ and $Y$.

\section{Combined ICC and FISH}

On the basis of the isolation procedure (resulting in about $80 \%$ epithelial cells) and the percentage of trisomy for chromosome 7 as detected by FISH (percentage range $15-70 \%$ ), it appeared likely that the cells with this aberration are epithelial in nature. Final proof, however, was obtained by a combination of ICC for cytokeratin 18 and FISH with a centromeric probe for chromosome 7 . The results of this experiment (Fig. 1, C-F) clearly show trisomy for chromosome 7 in epithelial cells, whereas non-epithelial cytokeratin-18-negative cells were generally diploid for chromosome 7 (not shown).

Correlation of chromosome aberrations with histopathological parameters Four $(30 \%)$ of the adenomas $\leq 1 \mathrm{~cm}(n=13)$ and $9(45 \%)$ of the adenomas $>1$ $\mathrm{cm}(n=20)$ appeared to be aberrant for at least one of the investigated 

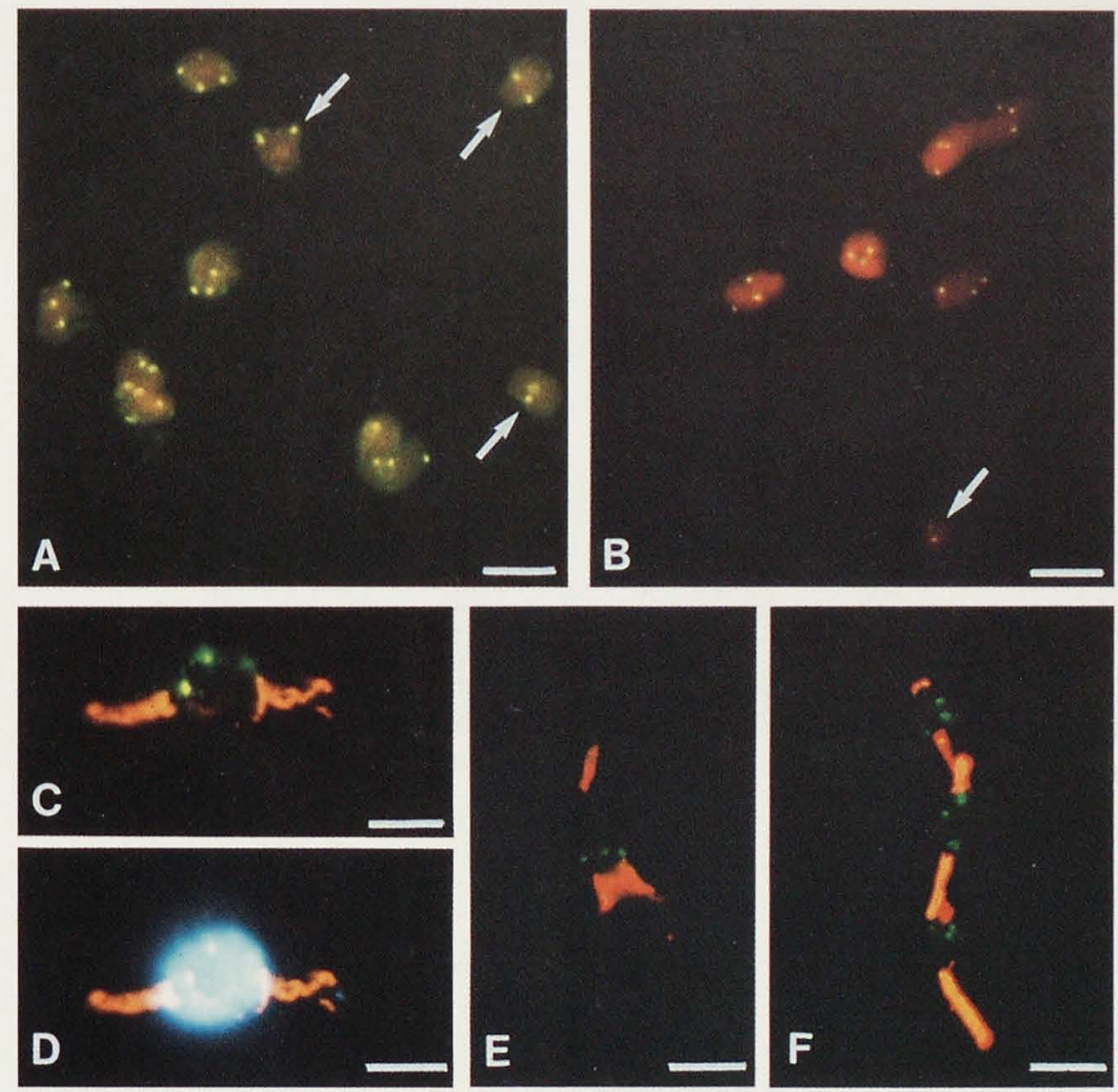

Figure 1. Results of FISH with a centromeric probe for chromosome 7 and combination of FISH and ICC for cytokeratin 18. Nuclei from epithelial cells were isolated from colon adenomas. $(A, B)$ Nuclei with trisomy and disomy (arrows) of chromosome 7. (C,D,E,F) Combination of ICC for cytokeratin 18 (alkaline phosphatase/Fast-Red reaction) and FISH. Counter staining for A,B with PI and for D with DAPI. Scale bars: A,B,E,F: $30 \mu \mathrm{m} ; \mathrm{C}, \mathrm{D}: 20 \mu \mathrm{m}$.

\section{chromosomes.}

Aberrations were detected in 11 (39\%) of the tubular adenomas, $2(40 \%)$ of the tubulovillous adenomas and 1 (50\%) villous adenoma. In addition, 3 hyperplastic polyps were investigated, in which no aberration was detected. Of the investigated adenomas $40 \%(n=2)$ with a mild degree of dysplasia, $38 \%(n=9)$ of the adenomas with moderate dysplasia and $50 \%(n=3)$ with severe dysplasia showed at least one chromosomal aberration. 


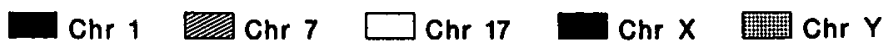

A

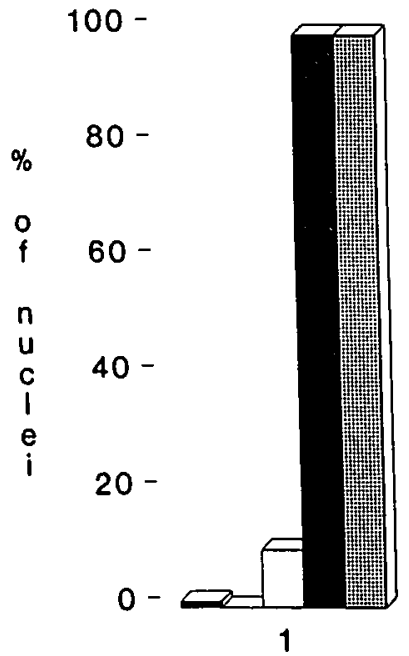

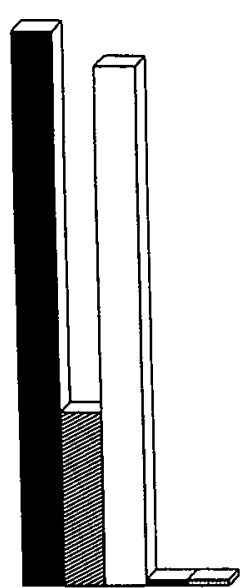

2

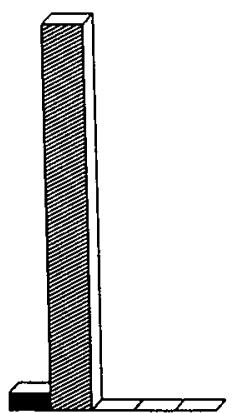

3

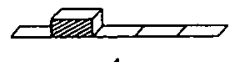

4

B

$\% 60-$

6

n $40-$

u

c

1

i $20-$

0 -

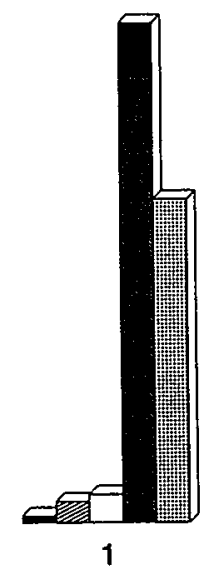

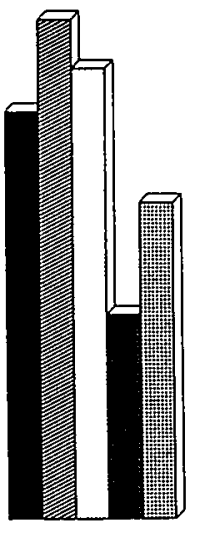

2

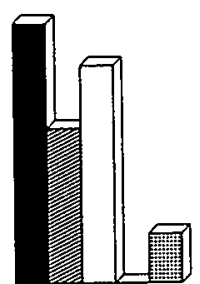

3

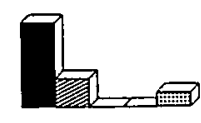

4

FISH signals per nucleus

Figure 2. Number of FISH signals per nucleus for the centromeric probes for chromosomes 1, 7, 17, X and $Y$ in case 13 (A) showing a trisomy for chromosome 7 in about $70 \%$ of the cells, and in case $18 d$ (B) showing numerous chromosomal aberrations.

\section{Heterogeneity within adenomas of one patient}

In a 55-year-old male patient (case 18) 7 distinct adenomas were detected, varying in size from 4 to $33 \mathrm{~mm}$. Six of these 7 adenomas were of a tubular phenotype and one was classified as a tubulovillous adenoma. The degree of 
dysplasia varied from moderate to severe. In 4 out of these 7 adenomas numerical chromosome aberrations were detected. In 2 samples (cases $18 \mathrm{a}$ and $18 f$ in Table 2) the numerical aberration found was a trisomy for chromosome 7. In the third sample (case18d) all the investigated chromosomes were aberrant and in the fourth sample (case 18b) trisomy of both chromosomes 7 and 17 was found.

\subsection{Discussion}

Most studies on chromosomal abnormalities of solid tumors are performed by karyotyping of (primary) cell cultures. To avoid artefacts caused by selective advantage during in vitro cell culture, we used interphase cytogenetics with FISH for quantitative studies of numerical chromosome aberrations. Because of the dense tissue structure of the colon epithelium and of celis in the crypts of the adenomas, we were not able to properly analyze nuclei in paraffin sections or frozen tissue sections used for FISH. Therefore, we were forced to use suspensions of cell nuclei obtained from fresh adenoma tissue.

In this study we detected no clear correlation between size, growth pattern and degree of dysplasia, on the one hand, and numerical chromosome aberrations on the other hand (Tables 1, 2). However, we must consider that the number of tubulovillous and villous adenomas, as well as adenomas with a mild or severe degree of dysplasia, is much smaller than the number of the tubular adenomas and adenomas with a moderate degree of dysplasia. In the case with multiple adenomas (case 18a-g in Table 1), 4 out of 7 samples showed chromosome aberrations (Table 2) and in 2 out of 7 adenomas a trisomy of chromosome 7 was found as the sole aberration. In this case the smallest adenoma showed this feature, indicating that occurrence of trisomy of chromosome 7 is independent of the size of these lesions.

A numerical loss of chromosome 17, which is considered to be a late event in the tumorigenesis of colon adenocarcinomas (Fearon and Vogelstein, 1990), was not found in the adenomas.

In this study, $40 \%$ of the colonic adenomas were aberrant for the investigated chromosomes. In DNA flow cytometry studies about $30 \%$ of the adenomas were aneuploid (Giaretti et al., 1988). Both results indicate that a fairly high percentage of colonic adenomas is aneuploid.

Our study points to two conclusions that need further discussion. Firstly, we conclude that trisomy for chromosome 7 is a frequent aberration in colon 
adenomas; it occurred in 13 out of 35 cases. In 6 of these, trisomy for chromosome 7 was the sole numerical aberration detected after screening with the 5 chomosome probes. The finding of trisomy for chromosome 7 in $40 \%$ of colorectal adenomas indicates that this aberration may be involved in the multistep process of tumorigenesis that leads to colorectal cancer (Fearon and Vogelstein, 1990). This model is based on the detection of multiple allelic losses in colorectal tumors. Gain of genes may be another factor in this model, which describes the multistep process of malignant transformation in colon, and one candidate gene that is located on chromosome 7 and may be involved in this process is the EGFR receptor gene. In this respect the cytogenetic study of Muleris et al. (1990) in 100 colorectal adenocarcinomas is of importance. These authors reported 22 tumors in which most of the anomalies represented chromosome gains, and therefore these lesions were called "trisomic tumors". The most frequently occurring change in these tumors was a trisomy for chromosome 7 , while in this cytogenetic class of "trisomic tumors" no loss of either chromosome $17 p$ or $18 q$ was observed. Although this does not exclude mutations on both chromosomes, one might suppose trisomy for chromosome 7 to be part of a different tumorigenic pathway.

The observation of trisomy for chromosome 7 in non-malignant tissues as reported in the literature (Bardi et al., 1991; Heim et al., 1989; Casalone et al., 1992; Dal Cin et al., 1992; Longy et al., 1990) had questioned the significance of this aberration as an event related to neoplasia. In some studies (Heim et al., 1989; Lee et al., 1987; Limon et al., 1990; Elfving et al., 1990; Casalone et al., 1992; Dal cin et al., 1992) trisomy for chromosome 7 was found in normal brain, lung and kidney tissue, but all tissue samples used for these studies were taken from tumor-bearing organs. Bardi et al. (1991) concluded from a study on colorectal adenocarcinomas that trisomy for chromosome 7 could be found in fibroblast-like cells, but on the other hand Williams et al. (1992) found trisomy for chromosome 7 in epithelial cells. These studies, however, were performed in tissue cultures of colon adenocarcinomas and it is well known that epithelial cells can assume a fibroblastoid phenotype under culture conditions (Greenburg and Hay, 1988). In a study by Arnoldus et al. (1991) on normal human brain tissue free of cancer, no trisomy for chromosome 7 was found. Further evidence for a role of this aberration in neoplastic growth comes from a study of head-and-neck cancer (Voravud et al., 1993) in which the frequency of cells with polysomy of chromosomes 7 and 17 increased as the tissue passed from histologically normal epithelium to cancer. In normal control oral epithelium from individuals free of 
cancer, no chromosome polysomy was found.

A second conclusion that can be drawn from our study is that trisomy for chromosome 7 in these adenomas is found in the epithelial component. This conclusion is based on the fact that the method of isolating the epithelial cells yields a suspension that contains at least $80 \%$ epithelial cells and about $20 \%$ stromal and inflammatory cells. Other strong evidence for this conclusion comes from the combination of cytokeratin immunocytochemistry and FISH. We found no trisomy for chromosome 7, either in the hyperplastic polyps, nor in 10 samples of normal colonic epithelium.

We conclude that for future studies, the combination of immunocytochemistry and FISH wil become a valuable method of examining the correlation between genetic and phenotypic characteristics. In order to determine the significance of trisomy for chromosome 7 as a neoplasia-related event in the colon, our next step will be the investigation of chromosome aberrations in tissue samples of normal mucosa, adenoma and adenocarcinoma all taken from the same patient.

\subsection{References}

Arnoldus EPJ, Noordermeer IA, Peters ACB, Raap AK, Van der Ploeg $M$ (1991) Interphase cytogenetics reveals somatic pairing of chromosome 17 centromeres in normal human brain tissue, but no trisomy 7 or sex-chromosome loss. Cytogenet Cell Genet 56:214216

Bardi G, Johansson B, Pandis N., Heim S, Mandahl N. Andrén-Sandberg A, Hägerstrand I, Mitelman $F(1991)$ Trisomy 7 in short-term cultures of colorectal adenocarcinomas. Genes Chromosom Cancer 3:149-152

Bardi G, Johansson B, Pandis N, Bak-Jensen E, Örndal C, Heim S, Mandahl N, AndrénSandberg $\AA$, Mitelman $F(1993)$ Cytogenetic aberrations in colorectal adenocarcinomas and their correlation with clinicopathologic features. Cancer 71:306-314

Casalone R, Granata Casalone P, Minelli E, Portentoso P, Righi R, Meroni E, Giudici A, Donati D, Riva C, Salvatore S, Bono AV (1992) Significance of the clonal and sporadic chromosome abnormalities in non-neoplastic renal tissue. Hum Genet 90:71-78

Dal Cin P, Aly MS, Delabie J, Ceuppens JL, Van Gool S, Van Damme B, Baert I, Van Poppel H, Van den Berghe $H$ (1992) Trisomy 7 and trisomy 10 characterize subpopulations of tumor-infiltrating lymphocytes in kidney tumors and in the surrounding kidney tissue. Proc Natl Acad Sci USA 89:9744-9748 
Elfving P, Cigudosa JC, Lundgren R, Limon J, Mandahi N, Kristoffersson U, Heim S, Mitelman $F(1990)$ Trisomy 7, trisomy 10, and loss of the $Y$ chromosome in short-term cultures of normal kidney tissue. Cytogenet Cell Genet 53:123-125

Fearon ER, Vogelstein B (1990) A genetic model for colorectal tumorigenesis. Cell 61:759-767

Giaretti W, Sciallero S, Bruno S, Geido E, Aste H, Di Vinci A (1988) DNA flow cytometry of endoscopically examined colorectal adenomas and adenocarcinomas. Cytometry 9:238244

Greenburg G, Hay ED (1988) Cytoskeleton and thyroglobulin expression during transformation of thyroid epithelium to mesenchyme-like cells. Development 102:605-622

Heim S, Mandahl N, Jin Y, Strömblad S, Lindström E, Salford LG, Mitelman F (1989) Trisomy 7 and sex chromosome loss in human brain tissue. Cytogenet Cell Genet 52:136138

Hopman AHN, Ramaekers FCS, Raap AK, Beck JLM, Devilee P, Van der Ploeg M, Vooijs GP (1988) In situ hybridization as a tool to study numerical chromosome aberrations in solid bladder tumors. Histochemistry 89:307-316

Lee JS, Pathak S, Hopwood V, Tomasovis B, Mullins TD, Baker FL, Spitzer G, Neidhart JA (1987) Involvement of chromosome 7 in primary lung tumor and nonmalignant normal lung tissue. Cancer Res 47:6349-6352

Limon J, Mrozek K, Heim S, Elfving P, Nedoszytko B, Babinska M, Mandahl N, Lundgren R, Mitelman $F(1990)$ On the significance of trisomy 7 and sex chromosome loss in renal cell carcinoma. Cancer Genet Cytogenet 49:259-263

Longy M, Saura R, Schouler L, Mauhin C, Goussot J-F, Grison O, Couzigou P (1990) Chromosomal analysis of colonic adenomatous polyps. Cancer Genet Cytogenet 49:249257

Muleris M, Salmon R-J, Dutrillaux B (1990) Cytogenetics of colorectal adenocarcinomas. Cancer Genet Cytogenet 46:143-156

Pinkel D, Landegent J, Collins C, Fuscoe J, Seagraves R, Lucas J, Gray J (1988) Fluorescence in situ hybridization with human chromosome-specific libraries: detection of trisomy 21 and translocations of chromosome 4. Proc Natl Acad Sci USA 85:9138-9142 
Ramaekers F, Huysmans A, Schaart G, Moesker O, Vooijs P (1987) Tissue distribution of keratin 7 as monitored by a monocional antibody. Exp Cell Res 170:235-249

Sandberg AA (1990) The chromosomes in human cancers and leukemia. 2nd ed. Elsevier, New York

Speel EJM, Schutte 8, Wiegant J, Ramaekers FCS, Hopman AHN (1992) A novel fluorescence detection method for in situ hybridization, based on the alkaline phosphataseFast Red reaction. J Histochem Cytochem 40:1299-1308

Voravud N, Shin DM, Ro JY, Lee JS, Hong WK, Hittelman WN (1993) Increased polysomies of chromosomes 7 and 17 during head and neck multistage tumorigenesis. Cancer Res 53:2874-2883

Whitehead RH, Brown A, Bhathal PS (1987) A method for the isolation and culture of human colonic crypts in collagen gels. In Vitro Cell Devel Biol 23:436-442

Willard HF, Waye JS (1987) Hierarchical order in chromosome-specific human alpha satellite DNA. Trends Genet 3:192-198

Williams AC, Harper SJ, Marshall CJ, Gill RW, Mountford RA, Paraskeva C (1992) Specific cytogenetic abnormalities and k-ras mutations in two new human colorectal-adenomaderived cell lines. Int J Cancer 52:785-790 
In situ hybridization and flow cytometric analysis of colorectal tumors suggests two routes of tumorigenesis characterized by gain of chromosome 7 or loss of chromosomes 17 and 18

Jos Herbergs, Anton HN Hopman, Adriaan P de Bruïne, Frans CS Ramaekers and Jan Willem Arends

$J$ Pathol, in press 


\section{Abstract}

Chromosomal aberrations in colon tumorigenesis were investigated by fluorescence in situ hybridization (FISH) with centromere specific DNA probes and correlated to flow cytometry (FCM) results of a series of tissues including normal colonic epithelium, adenomas and carcinomas, as well as adenomas adjacent to carcinomas.

No numerical chromosome aberrations were detected in normal colonic epithelium, except for an extra chromosome $X$ in one case. In the adenomas the most frequently occurring chromosome aberration was a trisomy for chromosome 7 , occurring in $37 \%$ of the cases. In the carcinomas two distinct routes of genetic aberrations could be established on basis of correlation with FCM: one with and one without endoreduplication. In the carcinomas without endoreduplication trisomy or tetrasomy for chromosome 7 was detected in 12 out of 15 cases $(80 \%)$. In 3 of these cases trisomy for chromosome 7 was found in combination with loss of chromosome 17 and/or chromosome 18 . In $87 \%$ of the carcinomas with endoreduplication loss of chromosome 17 and/or 18 was found, while only in one case gain of chromosome 7 was detected. In the adenomas adjacent to carcinomas trisomy for chromosome 7 was found in $36 \%$ of the cases. In these cases the concomitant adenocarcinomas showed the same numerical chromosome 7 aberration plus extra aberrations for other chromosomes. In only 2 cases the carcinoma demonstrated trisomy for chromosome 7 with a normal adjacent adenoma. These results suggest that gain of chromosome 7 is a significant aberration in the tumorigenesis of colonic carcinomas in which no endoreduplication occurred. No marked clinicopathological differences were observed between tumors of either route of tumorigenesis in our series.

\subsection{Introduction}

Tumor progression is considered to be a multistep process due to somatically acquired genetic changes, resulting in cells with a proliferative advantage together with a potential of invasive behaviour. Since the progression of colorectal neoplasia generally occurs via the adenoma-carcinoma sequence, a natural model is available for the investigation of genetic changes associated with tumor progression. On this basis the Vogelstein model for colon carcinogenesis (Fearon and Vogelstein, 1990) was developed, mainly based on the detection of 
loss of heterozygosity for several alleles or point mutation analyses. Next to such techniques for the detection of DNA alterations at the gene level, substantial information on chromosomal changes in colorectal carcinomas and adenomas has been acquired by karyotyping analyses of primary cell cultures from solid tumors (Muleris et al., 1990; Bardi et al., 1993; Longy et al., 1993) as well as from interphase cytogenetics with fluorescence in situ hy, ridization (FISH) (Herbergs et al., 1994) and flow cytometry (FCM) (Giaretti et al., 1989; Dean et al., 1992; Bauer et al., 1993).

One of the most frequent numerical abnormalities detected in colonic adenocarcinomas was a trisomy for chromosome 7 (Muleris et al., 1990; Bardi et al., 1993). The significance of trisomy for chromosome 7 in the tumorigenesis of colon carcinomas is debated, however, since the phenomenon was detected in fibroblast-like colonies after short-term culture of large bowel cancers (Bardi et al., 1991) while, furthermore, trisomy for chromosome 7 is also claimed to occur in nonneoplastic cells (Johansson et al., 1993). In our previous study (Herbergs et al., 1994), however, which revealed a high frequency of trisomy for chromosome 7 in colonic adenomas, this aberration was only found in epithelial cells isolated from adenomas as proven by the combination of cytokeratin immunocytochemistry and FISH.

In view of the high frequency of trisomy for chromosome 7 in colonic adenomas, the assumed progression from adenoma to carcinoma and the increasing DNA aneuploidy in the carcinoma, as previously shown on basis of FCM results by Dean et al. (1992), we focussed on the following questions: (1) is the frequency of occurrence of trisomy for chromosome 7 increasing within progressive lesions of the adenoma-carcinoma sequence in colon? (2) Is there a relation between the status of chromosome 7 in colonic carcinomas and concomitant adenomas? (3) Is gain of chromosome 7 associated with established chromosomal aberrations in colorectal tumorigenesis, like loss of chromosome 17 (p53 gene) and/or loss of chromosome 18 (DCC gene)? (4) is gain of chromosome 7 present in cases in which tetraploidization has occurred? To investigate these questions we combined FISH with centromere specific probes for chromosomes 1, 7, 9, 17 . 18, $X$ and $Y$ and $F C M$ on normal colonic epithelium, adenomas and carcinomas, as well as carcinomas with concomitant adenomas. FCM was performed to measure DNA content and classified the tumors as diploid, tetraploid or aneuploid. Furthermore the DNA content enables to determine relative loss or gain of chromosomes. 


\subsection{Materials and methods}

\section{Tissue samples}

Single cell suspensions were isolated from 35 consecutive adenomas as described before (Herbergs et al., 1994). Furthermore, tissue samples were used from freshly received resection specimens of adenocarcinomas $(n=23)$ and nearby adenomas $(n=11)$ and/or nearby colon epithelium resected $5 \mathrm{~cm}$ from the carcinoma $(n=11)$. Small blocks (maximum size $3 \mathrm{~cm}^{2}$ ) were snap frozen in precooled isopentane.

\section{Tumor cell processing}

Suspensions of single nuclei were prepared from $50 \mu \mathrm{m}$ thick frozen tissue sections by performing a proteolytic digestion step with pepsin from porcine stomach mucosa (2500- 3500 units per $\mathrm{mg}$ protein P-7000; Sigma, St. Louis, MO) at a concentration of $100 \mu \mathrm{g} / \mathrm{ml}$ in $0.01 \mathrm{~N} \mathrm{HCl}$ for $20 \mathrm{~min}$ at $37^{\circ} \mathrm{C}$. Suspensions of nuclei were diluted in $0.01 \mathrm{~N} \mathrm{HCl}$ to a total volume of $200 \mu \mathrm{l}$, spun onto poly-L-lysine (Mw. 150,000) coated slides and air dried. The slides were twice washed in $0.01 \mathrm{~N} \mathrm{HCl}$ and dehydrated in ethanol with a first step containing $70 \%$ ethanol $/ 0.01 \mathrm{~N} \mathrm{HCl}$.

\section{DNA probes}

For the detection of specific target sequences on chromosomes $1,7,9,17,18$, $X$ and $Y$, plasmid probes were used as described before (Willard et al., 1987). The probes were labeled by nick-translation with biotin 11-dUTP (Enzo, New York, NY) according to the suppliers instructions. The probes were hybridized in $60 \%$ formamide-2xSSC, $10 \%$ dextran sulphate and $1 \mu \mathrm{g} / \mu \mathrm{l}$ Salmon sperm DNA as carrier DNA, at a probe concentration of 2 to $6 \mathrm{ng} / \mu \mathrm{l}$ hybridization mixture. Under these stringency conditions, hybridization to minor binding sites was avoided.

\section{Fluorescence in situ hybridization (FISH)}

$10 \mu \mathrm{l}$ of the hybridization mixture were added to the slides under a coverslip (18 $\times 18 \mathrm{~mm}$ ). Denaturation was performed at $70-80^{\circ} \mathrm{C}$ on a heating plate in a moist chamber during 3-4 min. Hybridization was then performed overnight at $37^{\circ} \mathrm{C}$. Next, the slides were washed twice for $5 \mathrm{~min}$ in $60 \%$ formamide-2xSSC, $\mathrm{pH} 7.0$ at $42^{\circ} \mathrm{C}$ and subsequently twice in $2 \times S S C, \mathrm{pH} 7.0$ for $5 \mathrm{~min}$ at $42^{\circ} \mathrm{C}$ and in the same buffer for $5 \mathrm{~min}$ at room temperature.

Immunochemical detection was performed as previously described (Pinkel et al., 
Table 1. Numerical chromosome aberrations for chromosomes $1,7,17,18, X$ and $Y$ detected in 35 colon adenomas by means of FISH.

\begin{tabular}{lccccccc}
\hline & \multicolumn{7}{c}{ Investigated chromosomes } \\
& 1 & 7 & 17 & 18 & $X(\mathrm{~F})$ & $X(\mathrm{M})$ & $\mathrm{Y}$ \\
\hline Monosomy & $1 / 35$ & & & & $25 / 27$ & \\
Disomy & $30 / 35$ & $22 / 35$ & $30 / 35$ & $30 / 35$ & $6 / 8$ & $2 / 27$ & $24 / 27$ \\
Trisomy & $5 / 35$ & $13 / 35$ & $5 / 35$ & $4 / 35$ & $2 / 8$ & & $3 / 27$ \\
Tetrasomy & & $3 / 35$ & $1 / 35$ & $1 / 35$ & $1 / 8$ & & \\
\hline
\end{tabular}

1988). Evaluation of the preparations was performed by counting approximately 200 nuclei per slide, according to criteria described before (Hopman et al., 1988; Nederlof et al., 1989). Samples were considered to contain an aberrant population for one of the investigated chromosomes when the percentage of aberrant cells exceeded $15 \%$, which appeared to be a save margin since in nuclear preparations from normal mucosa the percentage of nuclei with an aberrant chromosome number \pm 2 SD did not exceed $10 \%$.

\section{Flow cytometry}

$50 \mu \mathrm{m}$ thick frozen tissue sections were fixed in $70 \%$ ethanol for $30 \mathrm{~min}$. and prepared for FCM according to standard procedures (Vindelov, 1977). For flow cytometric analyses a FACSort (Becton Dickinson, Sunnyvale, CA) equipped with a single Argon ion laser was used. Excitation was done at $488 \mathrm{~nm}$, and the emission filter used was 600 LP (red; PI). A minimum of 10,000 cells per sample were analyzed and data stored in list mode. The PI signals were recorded as linear amplified data. Data analysis was performed with the standard Lysis and cellfit software (Becton Dickinson). As a standard procedure for all analyses, data were gated on pulse processed PI signals to exclude doublets and larger aggregates.

\subsection{Results}

\section{Evaluation of FISH and FCM results:}

- Normal mucosa: No chromosomal aberrations were detected in the normal colon epithelia with the probes used, with the exception of one case where an 
Table 2. Detected numerical aberrations for chromosomes $1,7,9,17,18, X$ and $Y, D N A$ Index value, sex, age, Dukes' stage and site in 23 colon carcinomas. 'A, ascending; $T$, transverse; $D$, descending; $S$, sigmoid; $R$, rectum.

\begin{tabular}{|c|c|c|c|c|c|c|c|}
\hline \multirow[t]{2}{*}{ Nr. } & \multicolumn{7}{|c|}{ Chromosome copy nr. } \\
\hline & $\# 1$ & $\# 7$ & $\# 9$ & $\# 17$ & $\# 18$ & $\# x$ & $\# Y$ \\
\hline 1 & 2 & 2 & 2 & 2 & 2 & 1 & 1 \\
\hline 2 & 2 & 2 & 2 & 2 & 2 & 2 & \\
\hline 3 & 2 & 2 & 2 & 2 & 2 & 2 & \\
\hline 4 & 2 & $3(22 \%)$ & 2 & 2 & 2 & 1 & 1 \\
\hline 5 & 2 & $4(49 \%)$ & 2 & 2 & 2 & 2 & \\
\hline 6 & $3(82 \%)$ & $3(86 \%)$ & 2 & 2 & 2 & 1 & 1 \\
\hline 7 & 2 & $3(18 \%)$ & $3(24 \%)$ & 2 & 2 & $2(17 \%)$ & 1 \\
\hline 8 & $3(39 \%)$ & $3(56 \%)$ & $3(25 \%)$ & 2 & 2 & $2(40 \%)$ & 1 \\
\hline 9 & 2 & $3(31 \%)$ & $3(27 \%)$ & 2 & $3(23 \%)$ & 2 & \\
\hline 10 & 2 & $3(60 \%)$ & 2 & $3(64 \%)$ & 2 & 1 & $0(53 \%)$ \\
\hline 11 & 2 & $3(58 \%)$ & $3(53 \%)$ & 2 & 2 & 1 & 1 \\
\hline 12 & 2 & $3(55 \%)$ & $3(62 \%)$ & 2 & 2 & 2 & \\
\hline 13 & 2 & $3(56 \%)$ & 2 & 2 & $1(42 \%)$ & 2 & \\
\hline 14 & 2 & $3(27 \%)$ & 2 & 2 & $1(67 \%)$ & $2(66 \%)$ & 1 \\
\hline 15 & 2 & $3(58 \%)$ & $1(29 \%)$ & $1(42 \%)$ & $1(35 \%)$ & $1(27 \%)$ & \\
\hline \multirow[t]{2}{*}{16} & $2(82 \%)$ & $3(18 \%)$ & $3(26 \%)$ & $3(32 \%)$ & $3(29 \%)$ & $2(36 \%)$ & $0(46 \%)$ \\
\hline & & $4(28 \%)$ & & & $4(17 \%)$ & & $1(53 \%)$ \\
\hline 17 & $2(90 \%)$ & $4(31 \%)$ & $3(37 \%)$ & $2(87 \%)$ & $3(20 \%)$ & $2(60 \%)$ & $1(89 \%)$ \\
\hline 18 & $4(48 \%)$ & $4(75 \%)$ & $4(58 \%)$ & $2(95 \%)$ & $2(85 \%)$ & $1(88 \%)$ & $0(90 \%)$ \\
\hline \multirow[t]{2}{*}{19} & $3(18 \%)$ & $4(37 \%)$ & $4(50 \%)$ & $2(76 \%)$ & $2(73 \%)$ & $2(65 \%)$ & $2(57 \%)$ \\
\hline & $4(38 \%)$ & & & & & & \\
\hline \multirow[t]{2}{*}{20} & $3(55 \%)$ & $5(45 \%)$ & $2(89 \%)$ & $3(46 \%)$ & $2(85 \%)$ & $2(56 \%)$ & $0(47 \%)$ \\
\hline & & & & & & & $1(52 \%)$ \\
\hline 21 & $2(89 \%)$ & $3(50 \%)$ & $2(87 \%)$ & $3(50 \%)$ & $2(87 \%)$ & $2(60 \%)$ & $2(32 \%)$ \\
\hline \multirow[t]{2}{*}{22} & $3(16 \%)$ & $3(31 \%)$ & $3(25 \%)$ & $2(92 \%)$ & $2(86 \%)$ & $3(54 \%)$ & \\
\hline & $4(26 \%)$ & $4(43 \%)$ & $4(47 \%)$ & & & $4(24 \%)$ & \\
\hline \multirow[t]{2}{*}{23} & $3(30 \%)$ & $3(27 \%)$ & $3(36 \%)$ & $3(46 \%)$ & $2(87 \%)$ & $2(56 \%)$ & $1(89 \%)$ \\
\hline & $4(42 \%)$ & $4(42 \%)$ & & & & & \\
\hline
\end{tabular}


table 2 continued

\begin{tabular}{|c|c|c|c|c|c|}
\hline Nr. & DNA Index & Sex & Age & Dukes' stage & Site \\
\hline 1 & 1.0 & M & 54 & B & $s$ \\
\hline 2 & ND & $\mathbf{F}$ & 85 & B & $s$ \\
\hline 3 & 1.0 & $F$ & 81 & B & $s$ \\
\hline 4 & 1.0 & M & 73 & c & A \\
\hline 5 & 1.0 & $F$ & 78 & $c$ & $s$ \\
\hline 6 & 1.0 & $M$ & 81 & $c$ & $s$ \\
\hline 7 & 1.0 & $M$ & 50 & B & $R$ \\
\hline 8 & 1.0 & $M$ & 58 & c & $\mathrm{R}$ \\
\hline 9 & ND & $F$ & 87 & c & A \\
\hline 10 & ND & $M$ & 58 & B & $s$ \\
\hline 11 & 1.0 & M & 57 & c & $\mathrm{R}$ \\
\hline 12 & 1.0 & $\mathrm{~F}$ & 83 & B & A \\
\hline 13 & 0.9 & $\mathbf{F}$ & 72 & B & $S$ \\
\hline 14 & 1.0 & M & 72 & B & s \\
\hline 15 & 1.0 & $F$ & 82 & $B$ & $\mathbf{R}$ \\
\hline 16 & 1.8 & M & 51 & C & $s$ \\
\hline 17 & 1.8 & M & 74 & c & A \\
\hline 18 & 1.8 & $M$ & 83 & B & A \\
\hline 19 & 1.8 & $M$ & 72 & B & $s$ \\
\hline 20 & 1.8 & $M$ & 52 & B & $T$ \\
\hline 21 & 1.6 & $M$ & 79 & B & $\mathbf{s}$ \\
\hline 22 & 1.8 & $F$ & 62 & c & $\mathrm{R}$ \\
\hline 23 & 1.8 & $M$ & 70 & B & $\mathbf{R}$ \\
\hline
\end{tabular}


Table 3. Numerical chromosome aberrations for chromosomes $1,7,9,17,18, X$ and $Y$ in colon carcinomas and adjacent adenomas $(n=11)$. $A$, adenoom; $C$, carcinoom.

\begin{tabular}{|c|c|c|c|c|c|c|c|}
\hline \multirow[t]{2}{*}{ Nr." } & \multicolumn{7}{|c|}{ Chromosome copy nr. } \\
\hline & $\# 1$ & $\# 7$ & $\# 9$ & $\# 17$ & $\# 18$ & $\# x$ & $\# Y$ \\
\hline $2 \mathrm{C}$ & 2 & 2 & 2 & 2 & 2 & 2 & \\
\hline $2 A$ & 2 & 2 & 2 & 2 & 2 & $1(38 \%)$ & \\
\hline $6 \mathrm{C}$ & $3(82 \%)$ & $3(86 \%)$ & 2 & 2 & 2 & 1 & 1 \\
\hline $6 A$ & 2 & 2 & 2 & 2 & 2 & 1 & 1 \\
\hline $8 \mathrm{C}$ & $3(39 \%)$ & $3(56 \%)$ & $3(25 \%)$ & 2 & 2 & $2(40 \%)$ & 1 \\
\hline $8 A$ & 2 & $3(57 \%)$ & $3(61 \%)$ & 2 & 2 & 1 & 1 \\
\hline $9 \mathrm{C}$ & 2 & $3(31 \%)$ & $3(27 \%)$ & 2 & $3(23 \%)$ & 2 & \\
\hline $9 A$ & 2 & $3(65 \%)$ & 2 & 2 & 2 & 2 & \\
\hline $11 \mathrm{C}$ & 2 & $3(58 \%)$ & $3(53 \%)$ & 2 & 2 & 1 & 1 \\
\hline $11 \mathrm{~A}$ & 2 & $3(41 \%)$ & $3(37 \%)$ & 2 & 2 & 1 & 1 \\
\hline $13 \mathrm{C}$ & 2 & $3(56 \%)$ & 2 & 2 & $1(42 \%)$ & 2 & \\
\hline $13 \mathrm{~A}$ & 2 & $3(43 \%)$ & 2 & 2 & 2 & 2 & \\
\hline $15 \mathrm{C}$ & 2 & $3(58 \%)$ & $1(29 \%)$ & $1(42 \%)$ & $1(35 \%)$ & $1(27 \%)$ & \\
\hline $15 A$ & 2 & 2 & 2 & 2 & 2 & 2 & \\
\hline \multirow[t]{2}{*}{$16 \mathrm{C}$} & $2(82 \%)$ & $3(18 \%)$ & $3(26 \%)$ & $3(32 \%)$ & $3(29 \%)$ & $2(36 \%)$ & $0(46 \%)$ \\
\hline & & $4(28 \%)$ & & & $4(17 \%)$ & & $1(53 \%)$ \\
\hline $16 \mathrm{~A}$ & 2 & 2 & 2 & 2 & 2 & 1 & 1 \\
\hline $17 C$ & $2(90 \%)$ & $4(31 \%)$ & $3(37 \%)$ & $2(87 \%)$ & $3(20 \%)$ & $2(60 \%)$ & 1 \\
\hline $17 A 1$ & 2 & 2 & 2 & 2 & 2 & 1 & 1 \\
\hline $17 \mathrm{~A} 2$ & 2 & 2 & 2 & 2 & 2 & 1 & 1 \\
\hline \multirow[t]{2}{*}{$20 \mathrm{C}$} & $3(55 \%)$ & $5(45 \%)$ & $2(89 \%)$ & $3(46 \%)$ & $2(85 \%)$ & $2(56 \%)$ & $0(47 \%)$ \\
\hline & & & & & & & $1(52 \%)$ \\
\hline $20 \mathrm{~A}$ & 2 & 2 & 2 & 2 & 2 & 2 & 1 \\
\hline
\end{tabular}

extra chromosome $X$ was found.

- Adenomas: Table 1 shows the detected numerical aberrations for chromosomes $1,7,17,18, X$ and $Y$ in 35 adenomas. In all these cases only gain of chromosomes was detected, except for one case in which in part of the nuclei loss of chromosome 1 was found. The most frequently occurring chromosomal aberration was a trisomy for chromosome 7, which was found in 13 out of 35 carcinomas.

- Carcinomas: The adenocarcinomas were divided in two groups on basis of the results of combined FISH and FCM (Table 2). The first group $(n=15)$ consists of carcinomas with a DI value of about 1.0. In 3 of these carcinomas no 
chromosomal aberrations were detected. In 12 out of 15 cases a trisomy or tetrasomy 7 was observed; in 2 of these cases this was the only chromosomal aberration seen, in 7 cases the aberration was combined with mostly gain of chromosomes, like chromosome $1,9,17,18$ or $X$, and in 3 cases seen in combination with mostly loss of chromosomes, like $9,17,18$ or $X$. The second group $(n=8)$ consists of near-tetraploid carcinomas with a DI value of about 1.8 . In this group the most remarkable chromosomal aberrations detected were relative loss of chromosomes 17 and 18 in 3 cases, while only in 1 case (case 20) gain of chromosome 7 was observed.

- Adenomas adjacent to carcinomas: Table 3 shows eleven cases of carcinomas with concomitant adenomas. Five out of eleven adenomas showed numerical chromosome aberrations. In one case a loss of chromosome $X$ was found, in two cases a trisomy for chromosome 7 and in two cases a trisomy for chromosome 7 together with a trisomy for chromosome 9 . In the cases with a trisomy for chromosome 7 in the adenomas, the same aberrations plus extra aberrations were detected in the adjacent carcinomas (i.e., cases 8, 9, 11 and 13), which were all (near)diploid cases. In the four adenomas adjacent to hypotetraploid carcinomas no gain of chromosome 7 was detected.

\section{Clinicopathology and histopathology}

No marked differences were observed between the two groups of adenocarcinomas and Dukes' stage or site of the tumor (Table 2) as well as diameter, growth pattern or degree of dysplasia (not shown).

\subsection{Discussion}

The most striking finding of this study was a substantial number of adenomas and carcinomas showing trisomy for chromosome 7. The significance of this aberration in tumor development is debated, since this genomic change has been detected in carcinomas as well as in non-malignant tissues (Johansson et al., 1993). In our earlier study, however, trisomy for chromosome 7 was found to occur only in the epithelial compartment of colon adenomas (Herbergs et al., 1994).

In the present study we further analyzed the significance of gain of chromosome 7 in colon tumorigenesis. The copy number of chromosome 7 was therefore determined with FISH in several successive stages of colon tumor development. In normal colonic epithelium adjacent to carcinomas the absence of aberrations 


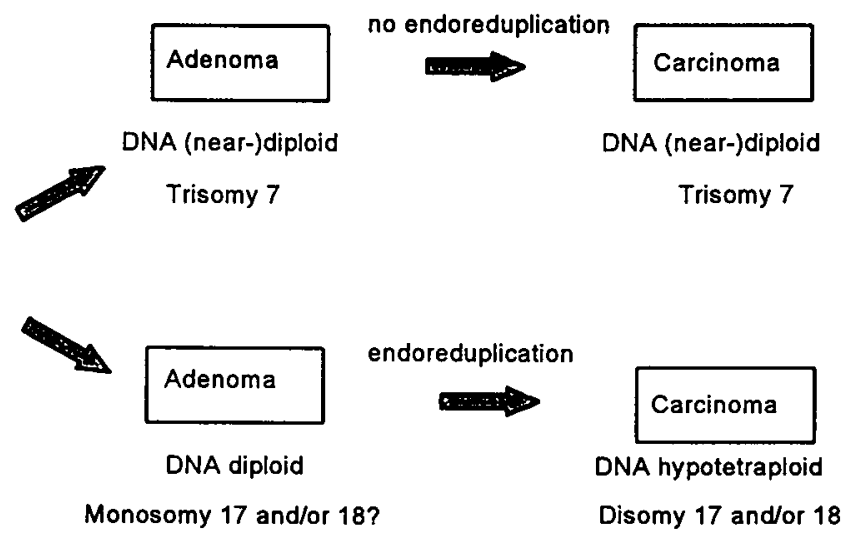

Figure 1. Hypothetical model of the two possible pathways in colon tumorigenesis, one route involving gain of chromosome 7 and one route involving endoreduplication and relative loss of chromosome 17 and/or 18 .

for chromosome 7 is a strong indication for the tumor specificity of chromosome 7 aberrations. Only in one normal case an extra chromosome $X$ was found, an aberration more often found in aging people (Abruzzo et al., 1985). In the investigated adenomas trisomy for chromosome 7 definitely was the most frequently occurring chromosome aberration with an increasing percentage of cases with gain of chromosome 7 in the adenoma-carcinoma sequence. The finding of trisomy for chromosome 7 as the most frequent chromosome aberration in adenomas is in agreement with other studies based on karyotyping analyses (Bardi et al., 1993; Longy et al., 1993). The percentage of chromosome 7 aberrations in carcinomas, however, appeared to be significantly higher than in these previously reported karyotyping studies (Muleris et al., 1990; Bardi et al., 1991), which can be due to a higher sensitivity of the FISH procedure. The increasing penetrance of gain of chromosome 7 in the adenoma-carcinoma sequence shown by our data implies that trisomy for chromosome 7 is an early genetic event. It is conceivable that an extra copy of this chromosome offers a growth advantage to an adenoma and therefore selects for adenomas with a malignant potential. Chromosome 7 harbours several growth factor (receptor) genes which could be candidates for selective growth advantage, such as the EGF receptor gene, the HGF gene and the ILGF-1 receptor gene. The cases in which gain of chromosome 7 was found in adenomas adjacent to carcinomas with the same status of chromosome 7 and extra chromosomal aberrations 
In situ hybridization and flow cytometric analysis...

support this concept. However, affection of the chromosome 7 status also occurs in more advanced stages in the adenoma-carcinoma sequence, as shown in the cases where adenomas with a normal copy content of chromosome 7 were found next to concomitant carcinomas with a gain of chromosome 7 . In any case, our data suggest that finding of trisomy for chromosome 7 in an adenoma is a prognostically infavourable sign.

Next to the increasing penetrance of trisomy for chromosome 7 in the adenomacarcinoma sequence, we investigated the occurrence of combined gain of chromosome 7 and other numerical chromosome aberrations, especially loss of chromosomes 17 anojor 18. In adenomas no loss of these chromosomes was detected, which is not surprising since it is assumed that these aberrations occur late in colon tumor development (Fearon and Vogelstein, 1990). In only a minority of (near)diploid carcinomas, combined gain of chromosome 7 and loss of chromosome 17 and/or 18 was observed. In contrast, in the hypotetraploid carcinomas relative loss of chromosome 17 and/or 18 was found in virtually all cases with only in one case a combined gain of chromosome 7 .

Given these data it is tempting to speculate that colon tumor development takes two seperate routes (Fig. 1), indicating two possible pathways of genetic changes: one route involving gain of chromosome 7 as the most frequently occurring chromosome aberration, with or without loss of chromosome 17 and/or 18. In this route endoreduplication does not seem to play a role. In the second route endoreduplication takes place with loss of chromosomal material, a chain of events which has already been described by Giaretti (1994). In this route gain of chromosome 7 is not a prominent phenomenon, but loss of chromosomes 17 and/or 18 is more striking. Our FISH data on adenomas adjacent to carcinomas are in line with this concept, the majority showing trisomy for chromosome 7 adjacent to near-diploid carcinomas, but no change in chromosome 7 status adjacent to tetraploid tumors.

In summary our data demonstrate that trisomy for chromosome 7 occurs in an increasing frequency in the adenoma-carcinoma sequence and that trisomy for chromosome 7 could be a prognostically unfavourable characteristic of adenomas. Furthermore, two routes of colon tumorigenesis are suggested: one route leading to (near)diploid carcinomas in which gain of chromosome 7 is found in the majority of the carcinomas and one route leading to hypotetraploid carcinomas which generally showed no gain of chromosome 7 , but loss of chromosome 17 and/or 18. In our smali series no evident correlation between the two suggested routes of tumorigenesis and clinicopathological data, in particular 
Dukes' stage, could be shown, but this will be subject to further investigations.

\subsection{References}

Abruzzo MA, Mayer M, Jacobs PA (1985) Aging and aneuploidy: evidence for the preferential involvement of the inactive $X$ chromosome. Cytogenet Cell Genet 39:275-278

Bardi G, Johansson B, Pandis N, Heim S, Mandahl N, Andrén-Sandberg Å, Hägerstrand I, Mitelman $F$ (1991) Trisomy 7 in short-term cultures of colorectal adenocarcinomas. Genes Chromosom Cancer 1991 3:149-152

Bardi G, Johansson B, Pandis N, Bak-Jensen E, Örndal C, Heim S, Mandahl N, AndrénSandberg Å, Mitelman F (1993) Cytogenetic analysis of 52 colorectal carcinomas - nonrandom aberration pattern and correlation with pathological parameters. Int $\mathrm{J}$ Cancer $55: 422-428$

Bauer KD, Bagwell CB, Giaretti W, Melamed M, Zarbo RJ, Witzig TE, Rabinovitch PS (1993) Consensus review of the clinical utility of DNA flow cytometry in colorectal cancer. Cytometry 14:486-491

Dean PA, Vernava III AM (1992) Flow cytometric analysis of DNA content in colorectal carcinoma. Dis Colon Rectum 35:95-102

Fearon ER, Vogelstein B (1990) A genetic model for colorectal tumorigenesis. Cell $61: 759-767$

Giaretti W, Sciallero S, Bruno S, Geido E, Aste H, Di Vinci A, d'Amore ES (1989) DNA flow cytometry of endoscopically examined colorectal adenocarcinomas. Path Res Pract $185: 589-593$

Giaretti W (1994) A model of DNA aneuploidization and evolution in colorectal cancer. Lab Invest 71:904-910

Herbergs J, De Bruïne AP, Marx PTJ, Vallinga MIJ, Stockbrügger RW, Ramaekers FCS, Arends JW, Hopman AHN (1994) Chromosome aberrations in adenomas of the colon. Proof of trisomy 7 in tumor cells by combined interphase cytogenetics and immunocytochemistry. Int J Cancer 57:781-785

Hopman AHN, Ramaekers FCS, Raap AK, Beck JLM, Devilee P, Van der Ploeg M, Vooijs GP (1988) In situ hybridization as a tool to study numerical chromosome aberrations in solid bladder tumors. Histochemistry 89:307-316 
Johansson B, Heim S, Mandahl N, Mertens F, Mitelman F (1993) Trisomy 7 in nonneoplastic cells. Genes Chromosom Cancer 6:199-205

Longy M, Saura R, Dumas F, Leseve JF, Taine L, Goussot J-F, Couzigou P (1993) Chromosome analysis of adenomatous polyps of the colon. Cancer Genet Cytogenet $67: 7-13$

Muleris M. Salmon R-J, Dutrillaux B (1990) Cytogenetics of colorectal adenocarcinomas. Cancer Genet Cytogenet 46:143-156

Nederlof PM, Van der Flier S, Raap AK, Tanke HJ, Van der Ploeg M, Kornips F, Geraedts JP (1989) Detection of chromosome aberrations in interphase tumor nuclei by nonradioactive in situ hybridization. Cancer Genet Cytogenet 42:87-98

Pinkel D, Landegent J, Collins C, Fuscoe J, Seagraves R, Lucas J, Gray J (1988) Fluorescence in situ hybridization with human chromosome-specific libraries: detection of trisomy 21 and translocations of chromosome 4. Proc Natl Acad Sci USA 85:9138-9142

Vindelov LL (1977) Flow microfluorometric analysis of nuclear DNA in cells from solid tumors and cell suspensions: a new method for rapid isolation and staining of nuclei. Virchows Arch [B] [Cell Pathol] 24:227-242

Willard HF, Waye JS (1987) Hierarchical order in chromosome-specific human alpha satellite DNA. Trends Genet 3:192-198 
Clonal origin of trisomy for chromosome 7 in the epithelial compartment of colon neoplasia

Jos Herbergs, Jan Willem Arends, Ernie MHF Bongers,

Frans CS Ramaekers and Anton HN Hopman

Genes Chromosom Cancer, in press 


\section{Abstract}

In this study, we demonstrated the clonal origin of trisomy for chromosome 7 in epithelial cells of colon neoplasia. By using the double-target fluorescence in situ hybridization (FISH) technique in frozen tissue sections that were also immunostained for keratin and vimentin, ratio analysis of FISH signals for chromosomes 7 and 17 could be performed in epithelial (cytokeratin-positive) or stromal (vimentin-positive) areas. The data demonstrated that trisomy for chromosome 7 is found exclusively in the epithelial compartments and not in the stroma of colon adenocarcinoma. We then demonstrated the occurrence of trisomy for chromosome 7 in the different types of epithelial neoplastic cells, i.e., columnar and goblet cells, which were isolated from frozen tissue sections by mechanical disaggregation of colon tissue and mild lysis of the cells while protease activity was inhibited. In these cell suspensions, the columnar cells were detected with an antibody to villin, and the goblet celis were stained for mucin, while all cells were subsequently subjected to FISH for chromosome 7. For analysis of neuroendocrine cells, whereas are present in a very low frequency in colon neoplasia, frozen tissue sections that were immunostained for Chromogranin A could be used. Individual neuroendocrine cells could be distinguished in these thin frozen tissue sections. The presence of trisomy for chromosome 7 in all three different epithelial cell types strengthens our suggestion that this chromosomal aberration is found in the epithelial stem cell compartment of colon neoplasia.

\subsection{Introduction}

Trisomy for chromosome 7 has been found as a clonal aberration in a variety of solid tumors (Mitelman, 1994). The aberration was frequently detected in tumors of the colon, bladder, kidney, lung, ovary, prostate, thyroid and brain. The biological significance of trisomy for chromosome 7 in tumorigenesis, however, has been disputed. In the kidney and brain, the aberration was detected in nonneoplastic epithelium (Heim et al., 1989; Knuutila et al., 1995). On the other hand, in prostate cancer, trisomy for chromosome 7 was correlated with a poor prognosis (Bandyk et al., 1994) and thyroid hyperplasias with a trisomy for chromosome 7 have been assumed to develop into adenomas or even into carcinomas (Belge et al., 1994). In colonic adenomas and carcinomas trisomy for chromosome 7 was one of the most frequently detected numerical genomic 
abnormalities (Muleris et al., 1990; Longy et al., 1993; Herbergs et al., 1994) and in a recent study by our group, it was shown that trisomy for chromosome 7 was involved in a distinct route of colon tumorigenesis (Herbergs et al., submitted). Furthermore, a discussion exists about the cell type in colon carcinomas that contains this genomic aberration, because it was claimed that trisomy for chromosome 7 occurred in fibroblast-like cells (Bardi et al., 1991). In cell suspensions from colon adenomas, however, trisomy for chromosome 7 was found in the epithelial cells by using combined cytokeratin immunocytochemistry (ICC) and fluorescence in situ hybridization (FISH)(Herbergs et al., 1994).

To study the clonal origin of trisomy for chromosome 7 in colon carcinoma, we first combined ICC for stromal and epithelial markers with double-target FISH for analysis of chromosome imbalances in frozen tissue sections. Double-target FISH was applied to circumvent the problem of truncated and overlapping nuclei in tissue sections. The ratio for the chromosomes 7 and 17 signals was determined in the different compartments of colon carcinoma.

Second, we studied the presence of trisomy for chromosome 7 in the individual cell types of colon neoplasia, i.e., the columnar, goblet, and neuroendocrine cell. From cell kinetic studies, it is known that colorectal epithelium continuously renews from the crypt base, where a stem-cell, common to these cell lineages, is presumed to reside (Chang and Leblond, 1971). The cells maturate as they migrate up the crypt towards the surface epithelium and differentiate into three different cell types, i.e., columnar cells that are reponsible for absorbtion and secretion, goblet cells that produce mucin and neuroendocrine cells that produce biogenic amines and peptide hormones. ICC with markers for these individual cell lineages and FISH with a centromeric probe for chromosome 7 were combined in the analysis of adenomas that were known to contain trisomy for chromosome 7 in a considerable fraction of the tumor cells. Our findings provide evidence for the occurrence of trisomy for chromosome 7 in the epithelial stem cell compartment of colon neoplasia.

\subsection{Materials and methods}

\section{Tissue samples}

Fresh tissue samples from two colon carcinomas and three colon adenomas were snap frozen in precooled isopentane and stored at $-70^{\circ} \mathrm{C}$. Colon adenomas were used with a trisomy for chromosome 7 in more than $20 \%$ of the cells (Herbergs et al., 1994). Four $\mu \mathrm{m}$ thick frozen tissue sections were mounted onto poly- $L$ - 
lysine coated slides, air dried and briefly fixed in methanol for $1 \mathrm{~min}$ at $-20^{\circ} \mathrm{C}$ and in acetone three times for $5 \mathrm{sec}$ at room temperature and air dried.

\section{Single cell suspensions}

To obtain reference values of the individual chromosome copy numbers for the carcinoma cases for comparison with the data obtained in their tissue sections, single cell suspensions were prepared from 50- $\mu$ m-thick sections after pepsin digestion $\left(100 \mu \mathrm{g} / \mathrm{ml}\right.$ pepsin in $0.01 \mathrm{~N} \mathrm{HCl}$ for $15 \mathrm{~min}$ at $\left.37^{\circ} \mathrm{C}\right)$.

For the adenoma cases the following protocol was used to obtain cell suspensions: $50 \mu \mathrm{m}$ thick frozen tissue sections were mechanically minced in a phosphate-buffered saline (PBS; pH 7.4)/protease inhibitor solution containing 2.5 $\mathrm{mM}$ phenylmethylsulfonyl fluoride (Sigma, St. Louis, MO), $12.5 \mu \mathrm{g} / \mathrm{ml}$ leupeptin (Sigma), and $10 \mu \mathrm{g} / \mathrm{ml}$ aprotinin (Sigma). Then $500 \mu \mathrm{l}$ lysis buffer (PBS, $10 \mathrm{mg} / \mathrm{ml}$ BSA, $0.2 \mu \mathrm{g} / \mathrm{ml}$ EDTA, and $0.5 \%$ Triton X-100, pH 7.4; Landberg and Roos, 1991) was added to $10^{6}$ cells per $\mathrm{ml}$ suspension on ice for $10 \mathrm{sec}$. For fixation, 3 $\mathrm{ml} 100 \%$ methanol $-20^{\circ} \mathrm{C}$ was added to $1 \mathrm{ml}$ of the suspension mixture incubated at room temperature for $10 \mathrm{~min}$. Cells were spun onto poly-L-lysine coated slides at $600 \mathrm{rpm}$ for $5 \mathrm{~min}$, air dried, washed for 5 minutes with PBS, and washed once with millio. The slides were dehydrated in an ethanol series, with a first step in $70 \%$ ethanol/0.01 $\mathrm{N} \mathrm{HCl}$.

\section{Antibodies}

The following monoclonal antibodies were used in this study: 1) Parlam 3 $(1: 100)$, a mucin reactive antibody, to detect goblet cells (Verstijnen et al., 1989), 2) an antibody to villin (1:50; MAB1671; Chemicon International, Temecula, CA) to detect columnar cells, 3) Chromogranin A (1:500; LK2H10; Hybritech, San Diego, CA) to detect neuroendocrine cells, 4) RCK106 (undiluted; Euro-Diagnostica B.V., Apeldoorn, The Netherlands) to detect epithelial cells and 5) an antibody to vimentin (1:10; RV202; Euro-Diagnostica B.V.) to detect stromal cells.

\section{Immunocytochemistry}

The slides were washed twice for 5 min in PBS containing $0.05 \%$ Tween 20 (buffer A) followed by incubation for $45 \mathrm{~min}$ at $37^{\circ} \mathrm{C}$ in the appropriately diluted primary antibody. After two washes of 5 min each with buffer $A$, the antibodies were detected by incubation with alkaline phosphatase-conjugated goat antimouse IgG (GAM-APase, diluted 1:25 in buffer A; DAKO A/S, Glostrup, Denmark) 
for $30 \mathrm{~min}$ at $37^{\circ} \mathrm{C}$. After two washes in buffer A ( 5 min each) APase activity was detected by the Fast Red precipitation reaction (Speel et al., 1992). The standard protocol was performed, with staining reagent containing $4 \mathrm{ml} 0.2 \mathrm{M}$ Tris-HCl buffer, $\mathrm{pH} 8.5,5 \%$ poly vinyl alcohol (PVA) (MW 40,000; Sigma), $1 \mathrm{mg}$ naphtol-ASMX-phosphate (Sigma) in $250 \mu$ buffer without PVA, and $5 \mathrm{mg}$ Fast Red TR salt (Sigma) in $750 \mu$ buffer without PVA. The reaction time was optimized for frozen tissue sections. The reaction was followed under the light microscope and allowed to run for a maximum of 10 minutes.

\section{FISH procedure}

After APase-Fast Red immunostaining of the specific cell protein under investigation, the slides were washed twice for $5 \mathrm{~min}$ in buffer $\mathrm{A}$, digested with $100 \mu \mathrm{g} / \mathrm{ml}$ pepsin in $0.01 \mathrm{~N} \mathrm{HCl}$ for $10 \mathrm{~min}$ at $37^{\circ} \mathrm{C}$, and washed twice for $5 \mathrm{~min}$ in $0.01 \mathrm{~N} \mathrm{HCl}$. Thereafter, the $\mathrm{FISH}$ procedure was performed as described previously (Hopman et al., 1988).

Centromere-specific probes for human chromosomes 7 and 17 were used (Willard and Waye, 1987). The DNA probes were labeled with either biotin-11-dUTP (ENZO, New York, NY), digoxigenin-11-dUTP, or fluorescein-12-dUTP (Boehringer Mannheim, Germany) in a standard nick-translation reaction.

Fluorescein isothiocyanate (FITC)-labeled DNA probes were detected by subsequent incubation with mouse anti-FITC (MAFITC, 1:500), FITC-conjugated rabbit anti-mouse IgG (RAM-FITC, 1:80) and FITC-conjugated swine anti-rabbit IgG (SWAR-FITC, 1:80; all from DAKO). Digoxigenin-labeled probes were detected with subsequent detection steps of mouse anti-digoxin (MADig, 1:2,000; Sigma), RAM-FITC and SWAR-FITC. The biotinylated probes were detected by subsequent incubation with amino methyl coumarin acetic acid (AMCA)-conjugated avidin (AvAMCA, 1:100)(Vector, Brunschwig Chemie, Amsterdam, The Netherlands), biotinylated goat anti-avidin (BioGAA, 1:100)(Vector), and again AvAMCA. In some cases the nuclei were counterstained with 4',6-diamidino-2-phenyl indole (DAPI; Sigma).

\section{Evaluation of FISH signals}

The ratio of FISH signals was determined for chromosome 7 and 17 in cytokeratin positive, vimentin positive and vimentin negative fields. Fifteen areas of about $2,500 \mu \mathrm{m}^{2}$ were analyzed per section. FISH was performed with the centromere specific probes for chromosomes 7 and 17 on single cell suspensions as described before (Herbergs et al., 1994), and 200 nuclei per case were analyzed. 

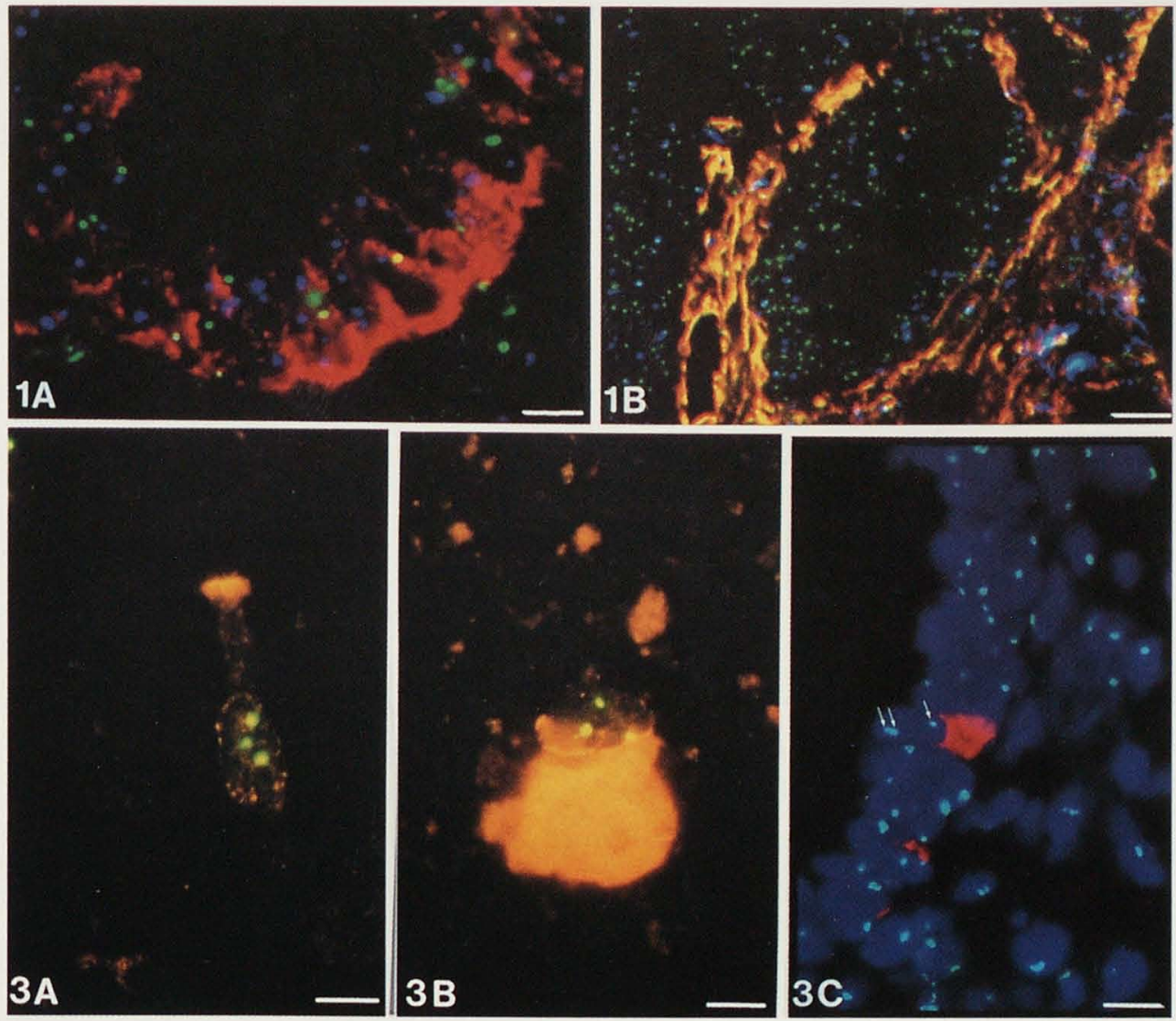

Figure 1. Frozen tissue sections of colon carcinoma that were subjected to immunocytochemistry (ICC) for cytokeratin (A) and vimentin (B), and to double-target fluorescence in situ hybridization (FISH). A) Cytokeratin staining in red, chromosome 7 in blue, and chromosome 17 in green. B) Vimentin staining in red, chromosome 7 in green, and chromosome 17 in blue. Scale bars $=15 \mu \mathrm{m}$ in A, $20 \mu \mathrm{m}$ in B.

Figure 3. Trisomy for chromosome 7 detected by FISH (green signals) in a villin positive columnar cell (A), a Parlam 3-positive mucinous cell (B) and a Chromogranin A-positive neuroendocrine cell (C); arrows showing chromosome signals). Scale bars $=10 \mu \mathrm{m}$ in $\mathbf{A}, \mathbf{B}, 15 \mu \mathrm{m}$ in $\mathbf{C}$.

Microphotographs were recorded with the Zeiss Axioskop or with the Metasystem Image Pro System (black and white CCD camera;, Fast Red in red, FITC in green or blue, AMCA in blue or green, and DAPI in blue. 


\subsection{Results}

Chromosome aberrations in the epithelial versus stromal compartments of colon carcinoma

In this study, we performed double-target FISH in combination with ICC for cytokeratin (carcinoma marker) and vimentin (stromal marker), which allowed to establish a signal ratio between two chromosomes within different tissue areas (Fig. 1A,B). For this purpose, a case of coloncarcinoma with a maximum ratio of the chromosome $7 / 17$ copy numbers (i.e., 3:1) was compared to a case with disomy for both (i.e., 1:1). The results from these analyses clearly demonstrate ratio differences in stromal and epithelial compartments.

In the two selected carcinoma cases the copy numbers for chromosomes 7 and 17 were first determined in isolated nuclear suspensions obtained from $50 \mu \mathrm{m}$ thick frozen tissue sections. In one case disomy for chromosome 7 was found in $87 \%$ of the nuclei and disomy for chromosome 17 in $83 \%$ of the nuclei. In the other case trisomy for chromosome 7 was found in $49 \%$ of the nuclei and monosomy for chromosome 17 in $42 \%$ of the nuclei. In the corresponding four $\mu \mathrm{m}$ thick tissue sections, the ratio for the FISH signals of chromosomes 7 and 17 was determined in 15 areas of $2,500 \mu \mathrm{m}^{2}$ each (Table 1). To distinguish between the carcinoma and stromal cells this ratio was estimated in cytokeratin-positive and cytokeratin-negative areas as well as in vimentin-positive and vimentinnegative areas, carcinoma cells being cytokeratin-positive and stromal cells being vimentin-positive. In case 1 , a ratio for chromosomes 7 and 17 of approximately 1.0 was found in the carcinoma compartment (cytokeratin-positive, vimentinnegative) as well as in the stroma (cytokeratin-negative, vimentin-positive). In case 2, a ratio of approximately 2.5 was observed in the carcinoma, whereas a ratio of approximately 1.0 was seen in the stromal compartment. The distribution of the individual ratios per area is shown in Figure 2. It is clear from these data that trisomy for chromosome 7 in combination with monosomy for chromosome 17 is restricted to the carcinoma, which exhibits an approximate 3:1 ratio. The stromal compartment of both cases clearly showed no overrepresentation of chromosome 7 compared to chromosome 17. From Table 1, it becomes also evident that the ratios are slightly higher for the carcinoma in vimentin-stained sections as compared to the carcinoma in cytokeratin-stained sections. This is probably due to rapid fainting of the AMCA signal used for the detection of chromosome 7. This also explains why a higher ratio was found in vimentinnegative areas compared to cytokeratin-positive areas, since the Fast Red 
Table 1. Ratio of chromosomes 7 and 17 (Mean \pm SD) in epithelial and stromal areas in two cases of colon carcinoma.

\begin{tabular}{|c|c|c|c|c|}
\hline & $\begin{array}{l}\text { Immunocytoc } \\
\text { staining }\end{array}$ & & $\begin{array}{l}\text { Analyzed } \\
\text { area }\end{array}$ & 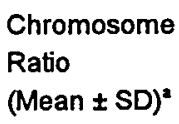 \\
\hline \multirow{4}{*}{$\begin{array}{l}\text { Case } 1 \\
(87 \% \text { disomy } 7 ; \\
\left.83 \% \text { disomy } 17^{b}\right)\end{array}$} & Cytokeratin & + & Epithelium & $1.0 \pm 0.2$ \\
\hline & & - & Stroma & $0.9 \pm 0.2$ \\
\hline & Vimentin & - & Epithelium & $1.0 \pm 0.1$ \\
\hline & & + & Stroma & $0.9 \pm 0.3$ \\
\hline \multirow{4}{*}{$\begin{array}{l}\text { Case } 2 \\
(49 \% \text { trisomy } 7 \\
\left.42 \% \text { monosomy } 17^{b}\right)\end{array}$} & Cytokeratin & + & Epithelium & $2.4 \pm 0.2$ \\
\hline & & - & Stroma & $1.1 \pm 0.3$ \\
\hline & Vimentin & - & Epithelium & $2.7 \pm 0.3$ \\
\hline & & + & Stroma & $0.9 \pm 0.3$ \\
\hline
\end{tabular}

- The ratio was determined in 15 areas of about $2500 \mu \mathrm{m}^{2}$ each.

Chromosome copy number determined in nuclei isolated from frozen tissue sections.

precipitate hampers analysis of AMCA signals, leading to a lower estimation of the chromosome 7 number.

Chromosome 7 aberrations in the different epithelial cell lineages in colon adenoma

For the analysis of trisomy for chromosome 7 in different epithelial cell lineages in colon tumors, three cases of adenomas with high percentages of nuclei with such an anomaly were selected and were immunocytochemically stained for markers of columnar, mucinous and neuroendocrine differentiation, i.e., villin, Parlam 3, and Chromogranin A, respectively. Subsequently, FISH with the chromosome 7 probe was applied to these cells. For staining of the columnar and goblet markers, single cell suspensions were used, which were obtained after mechanical disaggregation under protease protection conditions. The neuroendocrine cells, however, were detected in frozen tissue sections. We found trisomy for chromosome 7 in a considerable number of columnar as well as goblet 

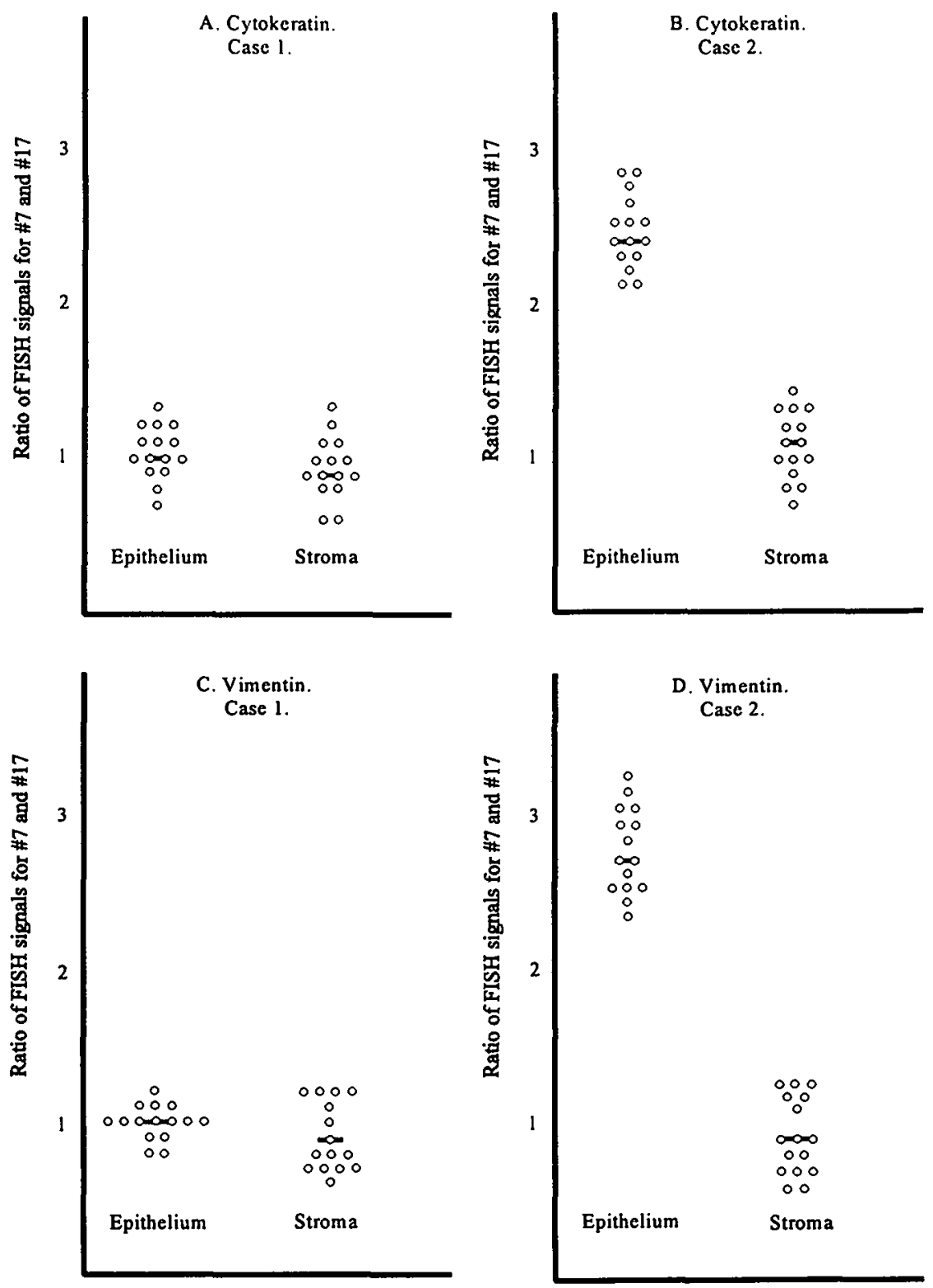

Figure 2. Mean and distribution of the ratios for chromosomes 7 and 17 in cytokeratin-stained sections in 15 epithelial compartments disomic for chromosomes 7 and 17 (A) or trisomic for chromosome 7 and monosomic for chromosome 17 (B); Vimentin stained sections in 15 stromal compartments disomic for chromosomes 7 and 17 (C) or in 15 epithelial compartments trisomic for chromosome 7 and monosomic for chromosome 17 (D). 
cells (Fig. 3A,B). Also, individual neuroendocrine cells with a trisomy for chromosome 7 were detected in the frozen tissue sections (Fig. $3 \mathrm{C}$ ).

\subsection{Discussion}

Interphase cytogenetics, as a tool for the study of genomic aberrations, is used increasingly in solid tumor diagnosis. The application of this technique to tissue sections, however, is hampered in general by nuclear truncation and overlap of individual nuclei. Our study shows that chromosome ratio analysis can overcome this problem and has major advantages over existing methods based on single-target FISH (Hopman et al., 1991; Dhingra et al., 1994; Alers et al., 1995; Pahlplatz et al., 1995). The method is independent of section thickness, no complex statistical analyses are needed, and aberrations can be rapidly detected in small areas of about 100 nuclei. A combination of double-target FISH and ICC provides the possibility of targeting the chromosome aberrations to specific tissue compartments.

Trisomy for chromosome 7 has been detected in a considerable fraction of colon adenomas and carcinomas. The question remained, however, as to which cell type of these tumors contained this anomaly (Bardi et al., 1991, 1995). Only few attempts have been made to correlate morphological or other phenotypic indicators on the one hand and the genomic changes on the other hand. This study has combined these parameters by applying FISH for chromosome 7 to colon tumor tissue sections and cell suspensions, which were immunocytochemically characterized. It has been established that only the epithelial tumor cells, and not the cells of the stromal compartment, were trisomic for chromosome 7.

Within the epithelial compartment of colon tumors the several lineages of differentiation contained this aberration, indicating its presence in the stem cell of colon neoplasia. This also implies that cells with trisomy for chromosome 7 can still differentiate and maturate normally and that it does not immediately lead to major functional changes. It is conceivable, however, that such a major chromosomal aberration, like an extra chromosome 7 , has an effect on cell growth and cell division, especially in the frequently dividing cells of colon crypts. The idea of a possible growth effect in colon epithelium is strengthened by the fact that the aberration, which is not found in normal colon epithelium, occurs in more than $30 \%$ of colon adenomas (Longy et al., 1993; Herbergs et al., 1994). Furthermore, the frequency of trisomy for 
chromosome 7 increases in the transition from colon adenomas to carcinomas and is involved in a pathway of tumor development in which gain of trisomy for chromosome 7 is found but no endoreduplication occurs (Herbergs et al., submitted). One of the candidate genes, located on chromosome 7 , is the epidermal growth factor receptor (EGFR). One could speculate that overexpression of this gene product, resulting from an extra copy of chromosome 7, disturbs the cascade involved in cell signal transduction. However, EGFR staining of ten cases of adenoma with and without trisomy for chromosome 7, revealed no clear-cut correlation between expression of the protein and copy numbers of chromosome 7 lour unpublished results). These results are in line with findings of Koretz et al. (1990), who found that the mode of EGFR expression in nonneoplastic and neoplastic epithelium is variable and is reflective of interindividual constitutive differences rather than of abnormalities in gene regulation.

In conclusion, we can state that trisomy for chromosome 7 in colon neoplasias is found in the epithelial compartments and not in the stromal compartments. It probably occurs at the level of the stem cell, because it is found in all three epithelial cell types.

\subsection{References}

Alers JC, Krijtenburg PJ, Vissers KJ, Bosman FT, Van der Kwast TH, Van Dekken H (1995) Interphase cytogenetics of prostatic adenocarcinoma and precursor lesions: Analysis of 25 radical prostatectomies and 17 adjacent prostatic intraepithelial neoplasias. Genes Chromosom Cancer 12:241-250

Bandyk MG, Zhao L, Troncoso P, Pisters LP, Palmer JL, Von Eschenbach AC, Chung LWK, Liang JC (1994) Trisomy 7: a potential cytogenetic marker of human prostate cancer progression. Genes Chromosom Cancer 9:19-27

Bardi G, Johansson B, Pandis N, Heim S, Mandahl N, Andrén-Sandberg A, Hägerstrand I, Mitelman F (1991) Trisomy 7 in short-term cultures of colorectal adenocarcinomas. Genes Chromosom Cancer 3:149-152

Bardi G, Pandis N, Fenger C, Heim S (1995) Trisomy 7 as the sole cytogenetic aberration in the epithelial component of a colonic adenoma. Cancer Genet Cytogenet $82: 82-84$ 
Belge G, Thode B, Rippe V, Bartnitzke S, Bullerdiek J (1994) A characteristic sequence of trisomies starting with trisomy 7 in benign thyroid tumors. Human Genet 94:198-202

Chang WW, Leblond $C P$ (1971) A unitarian theory of the origin of the three populations of epithelial cells in the mouse large intestine. Anat Rec 169:293

Dhingra K, Sneige N, Pandita TK, Johnston DA, Lee JS, Emami K, Hortobagyi GN, Hittelman WN (1994) Quantitative analysis of chromosome in situ hybridization signal in paraffin-embedded tissue sections. Cytometry 16:100-112

Heim S, Mandahl N, Jin Y, Strömblad S, Lindström E, Salford LG, Mitelman F (1989) Trisomy 7 and sex chromosome loss in human brain tissue. Cytogenet Cell Genet 52:136-138

Herbergs J, De Bruine AP, Marx PTJ, Vallinga MIJ, Stockbrügger RW, Ramaekers FCS, Arends JW, Hopman AHN (1994) Chromosome aberrations in adenomas of the colon. Proof of trisomy 7 in tumor cells by combined interphase cytogenetics and immunocytochemistry. Int J Cancer 57:781-785

Hopman AHN, Ramaekers FCS, Raap AK, Beck JLM, Devilee P, Van der Ploeg $M$, Vooijs GP (1988) In situ hybridization as a tool to study numerical chromosome aberrations in solid bladder tumors. Histochemistry $89: 307-316$

Hopman AHN, Van Hooren E, Van de Kaa CA, Vooijs PGP, Ramaekers FCS (1991) Detection of numerical chromosome aberrations using in situ hybridization in paraffin sections of routinely processed bladder cancers. Mod Path 4:503-513

Koretz K, Schlag P, Möller P (1990) Expression of epidermal growth factor receptor in normal colorectal mucosa, adenoma, and carcinoma. Virchows Archiv A Pathol Anat 416:343-349

Knuutila S, Larramendy ML, Elfving P, El-Rifai W, Miettinen A, Mitelman F (1995) Trisomy 7 in non-neoplastic tubular epithelial cells of the kidney. Hum Genet 95:149156

Landberg G, Roos G (1991) Antibodies to proliferating cell nuclear antigen as S-phase probes in flow cytometric cell cycle analysis. Cancer Res 51:4570-4574

Longy M, Saura R, Dumas F, Leseve J-F, Taine L, Goussot J-F, Couzigou P (1993) Chromosome analysis of adenomatous polyps of the colon. Cancer Genet Cytogenet 
$67: 7-13$

Mitelman F (1994) Catalog of Chromosome Aberrations in Cancer, Fifth Edition. New York: Wiley-Liss

Muleris M, Salmon R-J, Dutrillaux B (1990) Cytogenetics of colorectal adenocarcinomas. Cancer Genet Cytogenet 46:143-156

Speel EJM, Schutte B, Wiegant J, Ramaekers FCS, Hopman AHN (1992) A novel fluorescence detection method for in situ hybridization, based on the alkaline phosphatase-fast red reaction. J Histochem Cytochem 40:1299-1308

Pahlplatz MMM, De Wilde PCM, Poddighe P, Van Dekken $H$, Vooijs GP. Hanselaar AGJM (1995) A model for evaluation of in situ hybridization spot-count distributions in tissue sections. Cytometry 20:193-202

Verstijnen CPHJ, Arends JW, Moerkerk PTM, Pijls M, Kuypers-Engelen B, Bosman FT (1989) Colonic epithelium reactive monoclonal antibodies - Identification and immunohistochemical localization of target epitopes. Histochemistry 92:397-406

Willard HF, Waye JS (1987) Hierarchical order in chromosome-specific human alpha satellite DNA. Trends Genet 3:192-198 


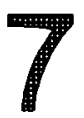

Epilogue 
This thesis consists of two coherent parts. The first part (Chapters 1 and 2) decribes technical improvements by combining immunocytochemistry (ICC) and fluorescence in situ hybridization (FISH) for the simultaneous detection of phenotypic and genotypic markers in tumor cells as well as the analysis of FISH signals in tissue sections. The second part (Chapters 3 to 6 ) deals with the significance of trisomy for chromosome 7 in colorectal tumorigenesis. It is demonstrated that trisomy for chromosome 7 is a frequently occurring chromosomal aberration in colorectal tumors, increasingly found in the adenomacarcinoma sequence. In chapter 5 a model is postulated in which trisomy for chromosome 7 is related to other chromosomal aberrations and in which two different routes for colon tumorigenesis are proposed. Furthermore, the clonal origin of trisomy for chromosome 7 in the epithelial compartments of colon neoplasia is demonstrated.

The genetic cascade described by Fearon and Vogelstein (1990) is a rather straightforward model for colorectal tumorigenesis. It is mainly based on restriction fragment length polymorphism (RFLP) studies demonstrating loss of heterozygosity, and not allowing the detection of gain of genomic material. Although this model has greatly contributed to our understanding of colon tumor development, it is tempting to speculate that it needs to be supplemented with information about gain of genetic material. In our study employing FISH, trisomy for chromosome 7 appeared to be a frequently occurring chromosomal aberration in about $30 \%$ of the adenomas and $60 \%$ of the carcinomas.

On the basis of our results of combined FISH and DNA flow cytometry, a model for colon tumorigenesis is conceived (Figure 1), suggesting two parallel routes: an endoreduplication pathway mainly showing loss of chromosomes 17 and 18, and a near-diploid pathway predominantly demonstrating trisomy for chromosome 7 . Compared with models for colon tumorigenesis based on DNA content (Giaretti, 1994 ) and karyotyping (Muleris et al., 1990) considerable consensus is seen. The pathway involving endoreduplication is described by Giaretti (1994) as well as Muleris et al. (1990). The pathway involving trisomy for chromosome 7 as a significant aberration, however, is a rare event according to Giaretti. Muleris et al. (1990) divide the near-diploid tumors into two separate groups, showing either gain of chromosomes, especially of chromosome 7, or loss of chromosomes, mainly chromosomes 17 and 18. In our studies, however, trisomy for chromosome 7 is frequently observed in both groups. Further investigations will be needed to analyze, whether this discrepancy may be due to selection occurring during the cell culture procedure, which is necessary for karyotyping 
studies.

Our investigations as well as those from others, so far, did not unambiguously answer the question whether trisomy for chromosome 7 in colorectal tumors is a significant genetic event in tumorigenesis. For the approach of this question it is necessary to obtain more information about the effect of this genomic aberration on the function of colonic epithelial cells. Since the anomaly is found in the different epithelial cell types, it appears not to have an immediate impact on cell differentiation. It is conceivable that trisomy for chromosome 7 occurs as a result of non-disjunction at mitosis and that genetic clones with this aberration obtain a growth advantage in comparison with surrounding cells. On basis of DNA flow cytometry and karyotyping studies, the existence of clonal heterogeneity in colorectal tumors seems very likely. Each clone may have its specific genotypic and phenotypic, as well as functional characteristics, which in combination and cooperation together will lead to development, further progression and metastasis of a tumor. On the other hand, it is just as possible that all characteristics necessary for tumor growth are to be found in one predominant clone, whereas subclones, if at all present, are either less aggressive, so that they will disappear, or more malignant, in which case these clones will outgrow the other clones. Investigation of possible heterogeneous occurrence of trisomy 7 in colonic neoplasia needs to be addressed to shed more light on these different putative pathways of tumorigenesis. Therefore, it is important to analyze genetic heterogeneity in colorectal tumors, and correlate the findings with morphological information, such as the degree of dysplasia. Furthermore, candidate genes on chromosome 7, which might be related to a possible growth advantage, require investigation. Combination of ICC and FISH can be used to investigate this relation in tissue sections. Additional valuable information about the meaning of trisomy for chromosome 7 in colon tumorigenesis, such as stage at which this aberration occurs in the adenoma-carcinoma sequence, can be obtained by studying the relation between trisomy for chromosome 7 and other genetic tumor markers known to be involved in colon tumorigenesis. In this context we attempted to correlate trisomy for chromosome 7 with codon $12 \mathrm{~K}$-ras point mutations in the same set of tumors, but could not detect a clearcut relation.

The technical improvents described in this thesis link up with the questions put above. The combination of ICC and FISH allows the simultaneous detection of phenotypic and genotypic characteristics of tumor cells, and by using this method we found strong indications for a clonal origin of trisomy 7 in the epithelial stem cell. In future studies the technique will enable to correlate genomic aberrations 


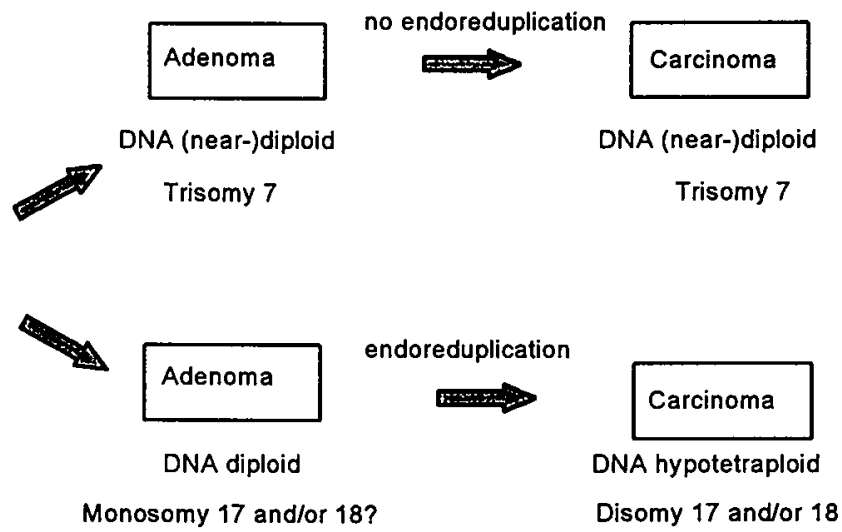

Figure 1. Hypothetical model of the two possible pathways in colon tumorigenesis, one route involving gain of chromosome 7 and one route involving endoreduplication and relative loss of chromosomes 17 and/or 18.

detectable by FISH with other colon tumor markers. Immunocytochemically detected p53 overexpression, for example, can be correlated with chromosomal aberrations found by FISH. Furthermore, expression of genes located on chromosome 7, resulting in proteins bearing potential tumorigenic characteristics, like plakoglobin or laminin $B$, can be correlated with the chromosome 7 copy number at the individual cell level. In a preliminary study we examined one of the possible candidate genes, the epidermal growth factor receptor, in a series of colon adenomas, but were unable to show a correlation between expression levels of this receptor and the copy number for chromosome 7.

The improvement of signal detection in tissue sections of colorectal neoplasia developed by our group allows a more refined correlation between chromosomal aberrations and morphological characteristics. This enables evaluation of heterogeneity of genomic changes in relation to different stages and grades of dysplasia and differentiation, phenomena often observed in colorectal neoplasms. In this light our plans for future studies, addressing the significance of trisomy for chromosome 7 in colon tumorigenesis, are: 1) the combined study of genotypic and phenotypic characteristics, like trisomy for chromosome 7 and gene products of candidate genes on chromosome $7 ; 2$ ) the combined analysis of genotypic characteristics, like trisomy for chromosome 7 in relation with other genomic aberrations ( $p 53, A P C, D C C$ ); and 3 ) the investigation of clonal heterogeneity for gain of chromosome 7 in tissue sections, possibly in combination with other 
genetic changes such as loss of chromosomes 17 and 18 .

\section{References}

Fearon ER, Vogelstein B (1990) A genetic model for colorectal tumorigenesis. Cell 61:759767

Giaretti (1994) A model of DNA aneuploidization and evolution in colorectal cancer. Lab Invest 71:904-910

Muleris M, Salmon RJ, Dutrillaux B (1990) Cytogenetics of colorectal adenocarcinomas. Cancer Genet Cytogenet 46:143-156 
Summary 
This thesis deals, firstly, with the technical improvement of protocols for the simultaneous detection of phenotypic and genotypic markers using immunocytochemistry (ICC) in combination with fluorescence in situ hybridization (FISH). Secondly, advances for analysis of FISH signals in tissue sections of colorectal cancer are described. Thirdly, chromosomal aberrations in colorectal adenomas and carcinomas are analyzed by FISH. Finally, the aberrant cell type is determined.

In a general introduction (chapter 1), the genomic changes sofar detected by DNA flow cytometry, karyotyping analysis and molecular genetics in colorectal neoplasia are described. On basis of the data obtained by these techniques several models are postulated, which describe a putative sequence of alterations during colorectal tumorigenesis.

In chapter 2 a protocol is described for the combination of ICC and FISH, which is applied for the simultaneous detection of phenotypic and genotypic markers. For ICC the alkaline phosphatase (APase)-Fast Red reaction is used, which has major advantages in combination with FISH. These advantages include an accurate protein localization, a stable reaction product during pepsin pre-treatment and during the entire FISH procedure, as well as favourable slow fading properties of the strong fluorescent signal of the Fast Red precipitate. Since extensive proteolytic digestion necessary for FISH can be applied to such preparations, autofluorescence is drastically reduced. Simultaneous use of the red fluorescent Fast Red precipitate and FITC or AMCA fluorochromes allows multiparameter detection of cell cycle parameters, as well as genotypic and phenotypic markers of tumor cells. The development of these methods is a prerequisite for the analysis of genomic changes in tissue sections of colon tumors and for the determination of the phenotype of the aberrant cell types.

In chapter 3 a method is described to improve the analysis of FISH signals in tissue sections, since evaluation of FISH signals in interphase nuclei of thin tissue sections from colon is hampered by truncation of the nuclei and a significant overlap of adjoining nuclei. The described method is based on a combination of lamin ICC and single- or double target FISH. The lamin ICC step reduces nuclear overlap by delineating nuclear contours, but also by physical trapping of the DNA and hence makes it possible to seperately recognize adjoining nuclei. This method allows analysis of FISH signals in individual nuclei and can be used to investigate genomic changes in different tumor compartments. The results, however, always involve an underestimation of the real chromosome copy numbers due to truncation of the nuclei. 
Trisomy for chromosome 7 clearly is the most frequently occurring chromosomal aberration detected in a series of 46 colorectal adenomas and 23 carcinomas, as shown in chapters 4 and 5 . In normal colonic epithelium trisomy for chromosome 7 is not detected, but in adenomas the aberration is found in about $30 \%$ of the investigated cases. In carcinomas gain of chromosome 7 is found in an even higher frequency, i.e., about $60 \%$ of all investigated cases. On basis of their DNA content the investigated carcinomas can be divided into two groups: a (near)diploid and a hypotetraploid group. In the (near)diploid carcinomas gain of chromosome 7 occurs in $80 \%$ of the tumors, either as the sole detected chromosomal aberration or in combination with other aberrations. In the hypotetraploid tumors, however, especially loss of chromosomes 17 and 18 are detected, while gain of chromosome 7 (as related to the DNA content) is detected in only one case. On basis of these results a novel model for colon tumorigenesis is conceived, suggesting two routes. One route involving trisomy for chromosome 7 at an early stage and another route involving loss of chromosomes 17 and/or 18, combined with DNA endoreduplication, resulting in hypotetraploid tumors.

To determine the cell type containing trisomy for chromosome 7 in cell suspensions of adenomas, cytokeratin ICC and FISH with a centromere specific probe for chromosome 7 are combined (chapter 4). It is demonstrated that trisomy for chromosome 7 is found in the epithelial cells, but the presence of trisomy 7 in stromal cells could at that stage not be excluded. In chapter 6 , however, the presence of trisomy for chromosome 7 is exclusively demonstrated in the epithelial compartments of colon neoplasia using double-target FISH in frozen tissue sections, which are immunostained for cytokeratin or vimentin. Chromosomal aberrations are detected by ratio analysis of FISH signals for chromosomes 7 and 17.

In addition, the presence of trisomy for chromosome 7 is demonstrated in the different lineages of epithelial differentiation present in colon neoplasia, namely the columnar, goblet, and neuroendocrine cells, which are ICC stained with antibodies against villin, Parlam 3 and Chromogranin $A$, respectively. The detection of trisomy for chromosome 7 in these different cell types indicates the origin of this aberration in the stem cell compartment.

From our investigations we conclude that trisomy for chromosome 7 is increasingly found in the colorectal adenoma-carcinoma sequence, suggesting this genomic aberration to be a prognostically unfavourable characteristic in adenomas. Furthermore, according to our postulated model for colon 
tumorigenesis, trisomy for chromosome 7 is particularly found in the pathway, during which no endoreduplication occurs. We also demonstrate that the anomaly is exclusively found in the epithelial compartment of colonic neoplasia and not in the stromal cells. It probably occurs at the level of the stem cell since it is found in all three epithelial cell lineages that can be distinguished by ICC in colorectal cancer. In the epilogue (chapter 7) possible future directions of research are discussed to more definitively establish the significance of trisomy for chromosome 7 in the colorectal tumorigenesis. 


\section{Samenvatting}

Dit proefschrift beschrijft allereerst de technische verbeteringen noodzakelijk voor simultane detectie van zowel fenotypische alsook genotypische karakteristieken van tumorcellen. Hierbij wordt gebruik gemaakt van gecombineerde immunocytochemie (ICC) en fluorescentie in situ hybridizatie (FISH). Deze methodiek kan onder andere gebruikt worden voor een directe analyse van FISH signalen in weefselcoupes van colorectale tumoren. Vervolgens is een overzicht gegeven van de chromosomale afwijkingen die m.b.v. de FISH techniek zijn gevonden in colorectale adenomen en carcinomen. Tenslotte is bepaald welk celtype afwijkend is in de tumoren.

In een algemene inleiding (hoofdstuk 1) zijn de genetische afwijkingen beschreven zoals die tot dusver in colorectale tumoren gedetecteerd zijn m.b.v. DNA flow cytometry, karyotypering en moleculair genetische technieken. Op basis van de data verkregen met deze technieken zijn verschillende hypothetische modellen opgesteld die een mogelijke volgorde van de genetische afwijkingen weergeven zoals die optreden tijdens het ontstaan en de proliferatie van colorectale kanker. In hoofdstuk twee is een methode beschreven voor de simultane detectie van fenotypische en genotypische karakteristieken van tumorcellen m.b.v. gecombineerde ICC en FISH. Voor de ICC is gebruik gemaakt van de alkalische fosfatase-Fast Red reactie vanwege de voordelige eigenschappen in combinatie met FISH. Dit zijn o.a. een nauwkeurige eiwitlokalisatie en een geringe bleking van het fluorescentie signaal van het Fast Red precipitaat. Aangezien ook een sterke proteolytische digestie met behulp van pepsine mogelijk is, wordt de autofluorescentie drastisch gereduceerd. Simultaan gebruik van het fluorescerende Fast Red precipitaat (rood) en FITC (groen) of AMCA (blauw) fluorochromen maakt een multiparameter detectie mogelijk van zowel celcyclus parameters, alsook genotypische en fenotypische karakteristieken van tumorcellen. De ontwikkeling van deze methodieken is een voorwaarde voor de analyse van genomische veranderingen in weefselcoupes van colontumoren en voor de bepaling van het fenotype van de afwijkende celtypes.

In hoofdstuk 3 is een methode beschreven ter verbetering van de analyse van FISH signalen in weefselcoupes, aangezien evaluatie van FISH signalen wordt bemoeilijkt door beschadiging en overlapping van de kernen. De methode is gebaseerd op een combinatie van lamine ICC en enkelvoudige of dubbele FISH. De lamine kleuring m.b.v. het Fast Red precipitaat reduceert overlap van de kernen door de kerncontour weer te geven en door stabilisatie van het DNA 
binnen deze contour. Hierdoor is het mogelijk om individuele kernen te onderscheiden en chromosomale veranderingen in deze kernen te onderzoeken. De resultaten geven echter altijd een onderwaardering van het werkelijke chromosoom aantal weer als gevolg van beschadiging van de kernen.

In hoofdstuk 4 en 5 blijkt dat de meest frequent gevonden chromosomale afwijking in een serie van 46 colorectale adenomen en 23 carcinomen een trisomie voor chromosoom 7 is. In normaal colonepitheel is deze afwijking niet aangetoond, in adenomen in ongeveer $30 \%$ van de onderzochte tumoren en in carcinomen in ongeveer $60 \%$ van de onderzochte tumoren. Op basis van de DNAinhoud zijn de onderzochte carcinomen verdeeld in twee groepen: een (bijna)diploïde groep en een hypotetraploïde groep. In de (bijna)-diploïde carcinomen wordt een extra chromosoom 7 gevonden in ongeveer $80 \%$ van de tumoren: als enige gedetecteerde chromosomale afwijking of in combinatie met andere afwijkingen. In de hypotetraploïde tumoren wordt vooral verlies van de chromosomen 17 en 18 aangetoond, terwijl een extra chromosoom 7 (gerelateerd aan de DNA inhoud) slechts in én tumor wordt aangetoond. Op basis van deze resultaten is een nieuw model voor colon tumorontwikkeling voorgesteld, gebaseerd op twee verschillende routes: in de eerste route treedt in een vroeg stadium trisomie voor chromosoom 7 op, terwijl in de andere route verlies van chromosomen 17 en/of 18 optreedt in combinatie met DNA endoreduplicatie, uiteindelijk resulterend in hypotetraploïde tumoren.

Om in celsuspensies van colonadenomen het celtype te bepalen waarin een trisomie voor chromosoom 7 gevonden wordt, is cytokeratine ICC en FISH met een centromeer specifieke probe voor chromosoom 7 gecombineerd (hoofdstuk 4). Hierbij is aangetoond dat trisomie voor chromosoom 7 wordt aangetroffen in de epitheliale cellen. De aanwezigheid van trisomie voor chromosoom 7 in stromale cellen kon echter niet worden uitgesloten. In hoofdstuk 6 is specifiek in de epitheliale compartimenten van colontumoren de aanwezigheid van trisomie voor chromosoom 7 aangetoond door in weefselcoupes gebruik te maken van gecombineerde dubbele FISH en een immunokleuring voor cytokeratine of vimentine. Chromosomale afwijkingen zijn hierbij gedetecteerd door de verhouding te bepalen van de FISH signalen voor de chromosomen 7 en 17. Vervolgens hebben we de aanwezigheid van trisomie voor chromosoom 7 aangetoond in de verschillende subtypes van epitheliale differentiatie in colonepitheel, namelijk columnaire cellen, slijmbeker cellen en neuroendocriene cellen. Deze werden gedetecteerd m.b.v. antilichamen tegen respectievelijk villine, Parlam 3 en Chromogranine A. Trisomie voor chromosoom 7 werd hierbij 
aangetoond in alle verschillende celtypes, indicatief voor een oorsprong van deze afwijking vanuit de stamcel.

Samengevat kunnen we concluderen we dat trisomie voor chromosoom 7 in toenemende mate gevonden wordt in de colorectale adenoma-carcinoma opeenvolging, suggererend dat deze genetische afwijking een prognostisch ongunstige eigenschap is in adenomen. Naar aanleiding van ons gepostuleerde model voor colon tumorontwikkeling concluderen wij verder dat trisomie voor chromosoom 7 met name gevonden wordt in een route waarin geen endoreduplicatie plaatsvindt. Verder is aangetoond dat deze anomalie uitsluitend gevonden wordt in de epitheliale compartiment van colontumoren en niet in de stromale cellen. Waarschijnlijk treedt deze afwijking reeds op stamcel niveau op, aangezien trisomie voor chromosoom 7 gevonden is in de verschillende epitheliale celtypes die m.b.v. ICC aangetoond kunnen worden. In de epiloog (hoofdstuk 7) worden mogelijk toekomstige studies bediscussieerd die meer uitsluitsel kunnen geven over de significantie van trisomie voor chromosoom 7 in colorectale tumorontwikkeling. 


\section{DANKWOORD}

Dierbare lezer van dit boek of van deze pagina: niet iedereen waar ik (prettig) mee gewerkt heb of weleens een gezellig (of opbeurend) geprek mee heb gevoerd, zal op de volgende pagina's genoemd zijn. Ik hoop dat me dat niet kwalijk genomen wordt: ook al ben je niet persoonlijk genoemd, je hebt toch een bijdrage geleverd aan dit proefschrift en aan een voor mij prettige en leerzame tijd op de afdelingen Pathologie en Moleculaire Celbiologie \& Genetica.

Degene die het meest betrokken was bij mijn onderzoek is natuurlijk Ton. Beste Ton, dankzij jou heb ik geleerd hoe je met twee en drie (al of niet valse) kleuren een hoop kunt bereiken op het gebied van tumor onderzoek. Ook heb ik veel gehad aan je scherpe analytische geest ten aanzien van de verworven data, waardoor regelmatig schijnbare chaos in orde veranderde. Dit boekje is zeker voor een groot deel jou verdienste.

Misschien dat het voor sommigen niet helemaal duidelijk geweest is, maar uiteindelijk was ik al die tijd een aio van de pathologie. Beste Jan-Willem, jou is dit in ieder geval niet ontgaan. Al zag je mij af en toe met lede ogen richting Moleculaire Celbiologie gaan om mijn experimenten te doen, je zorgde er wel voor dat daarbij de link met de pathologie niet uit het oog verloren werd, wat zeker terug te vinden is in dit proefschrift. Naast het noodzakelijke wetenschappelijk overleg kwamen we elkaar ook buiten werktijd regelmatig tegen en dan was er meestal sprake van een "culturele uitwisseling" tijdens een van onze ontmoetingen in het theater.

Ook mijn tweede promotor kwam ik geregeld in mijn vrije tijd tegen. Helaas waren dit over het algemeen korte ontmoetingen, want, beste Frans, na de start van een hardloopwedstrijd zag ik je meestal niet meer terug. Gelukkig gold dat niet voor de tijd dat ik mijn promotie onderzoek heb gedaan. Met bloed, zweet en tranen is er regelmatig aan artikelen gewerkt, maar uiteindelijk altijd met een vruchtbaar resultaat.

Als aio is het regelmatig nodig om advies te vragen aan een "oude rot in het vak". Beste Ernst-Jan, gedurende de afgelopen jaren ben je mijn grote vraagbaak geweest (tot aan de laatste loodjes toe), maar daarnaast natuurlijk ook een gezellige en prettige kamergenoot. Mister Spiel, bedankt.

Een onvermijdelijk kwaad waarmee je te maken krijgt, is het begeleiden van studenten. Beste Ernie, je weet natuurlijk wel beter. Je enthousiasme en gedrevenheid werkten heel stimulerend en ik heb je dan ook altijd met veel plezier begeleid. Dat geldt ook voor jou, beste Mary, al had je de pech dat je net aan het 
einde van mijn aio periode begon, waardoor ik toch af en toe tijd te kort kwam voor een goede begeleiding. Je bent gelukkig een zelfstandige persoonlijkheid en hebt aan een half woord genoeg gehad om je onderzoek te doen.

Zonder samenwerking bereik je bijzonder weinig in onderzoek. Speciale dank gaat daarom uit naar de medewerkers van de endoscopie voor het verzamelen van de poliepen en naar Adriaan, "Antonio", Edith, Sjaak, Margriet en Patrick van de afdeling Pathologie. Annick, Christien, Edith, Elena, Joris, Manon, Marie-Hélène, Maurice, Miriam, Monique: als labgenootjes zijn jullie onvergetelijk, net als iedereen waar ik mee samengewerkt heb.

Pap en mam: "bedaankt veur al 't vertrouwe dat er ummer in mich hat gehat en dat dur mich de meugelijkheed hat gegeve om miene ege weg te goan".

Lieve Chantal, woorden hebben geen betekenis waar het om gevoelens gaat. Talleke, bedankt. 


\section{CURRICULUM VITAE}

Jos Herbergs werd geboren op 22 mei 1963 te Bocholtz. In 1981 behaalde hij het examen gymnasium- $\beta$ aan het gymnasium Rolduc te Kerkrade. Na een jaar Milieuhygiëne aan de Landbouw Hogeschool Wageningen, vervulde hij zijn dienstplicht bij de Audiovisuele Dienst te Den Haag. In 1984 begon hij met de studie Biologie aan de Katholieke Universiteit Nijmegen. Het doctoraal examen, binnen de fysiologisch/biochemische afstudeerrichting, werd in augustus 1990 behaald. Tijdens deze studie was hij betrokken bij onderzoeksprojecten op de afdelingen Dierfysiologie (Prof. dr. S.E. Wendelaar Bonga) en Anthropogenetica (Prof. dr. H.H. Ropers). Op deze laatste afdeling werkte hij als vrijwilliger onder begeleiding van Prof. dr. A. Geurts van Kessel tot hij in 1991 als Assistent in Opleiding in dienst trad bij de vakgroep Pathologie (Prof. dr. J.W. Arends) van het Academisch Ziekenhuis te Maastricht. Het onderzoek werd uitgevoerd in samenwerking met de vakgroep Moleculaire Celbiologie \& Genetica van de Rijksuniversiteit Limburg (Prof. dr. F.C.S. Ramaekers en Dr. A.H.N. Hopman).

Per 1 april 1996 is hij werkzaam als post-doctoraal toegevoegd onderzoeker in het kader van een door de EU gefinancieerd project bij de vakgroep Veefokkerij (Prof. dr. ir. E.W. Brascamp) van de Landbouw Universiteit Wageningen. 